
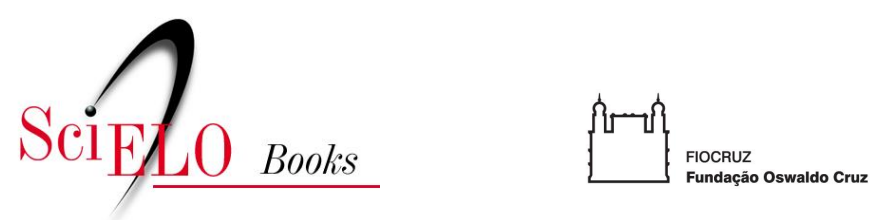

Ipea $\begin{gathered}\text { Instituto de Pesquisa } \\ \text { Econominica Aplicada }\end{gathered} \quad \begin{gathered}\text { Mistério da } \\ \text { Saúde }\end{gathered}$

\title{
Estruturas de financiamento e gasto do sistema público de saúde
}

\author{
Sérgio Francisco Piola \\ Luciana Mendes Santos Servo \\ Edvaldo Batista de Sá \\ Andrea Barreto de Paiva
}

\section{SciELO Books / SciELO Livros / SciELO Libros}

PIOLA, SF., et al. Estruturas de financiamento e gasto do sistema público de saúde. FUNDAÇÃO OSWALDO CRUZ. A saúde no Brasil em 2030 - prospecção estratégica do sistema de saúde brasileiro: estrutura do financiamento e do gasto setorial [online]. Rio de Janeiro:

Fiocruz/Ipea/Ministério da Saúde/Secretaria de Assuntos Estratégicos da Presidência da República, 2013. Vol. 4. pp. 19-70. ISBN 978-85-8110-018-0. Available from SciELO Books <http://books.scielo.org>.

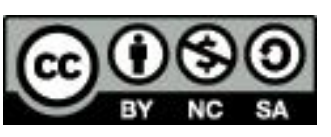

All the contents of this chapter, except where otherwise noted, is licensed under a Creative Commons Attribution-Non Commercial-ShareAlike 3.0 Unported.

Todo o conteúdo deste capítulo, exceto quando houver ressalva, é publicado sob a licença Creative Commons Atribuição Uso Não Comercial - Partilha nos Mesmos Termos 3.0 Não adaptada.

Todo el contenido de este capítulo, excepto donde se indique lo contrario, está bajo licencia de la licencia Creative Commons Reconocimento-NoComercial-CompartirIgual 3.0 Unported. 
Estruturas de Financiamento e Gasto do Sistema Público de Saúde 


\title{
ESTRUTURAS DE FINANCIAMENTO E GASTO DO SISTEMA PÚBLICO DE SAÚDE ${ }^{1}$
}

\author{
Sérgio Francisco Piola \\ Luciana Mendes Santos Servo \\ Edvaldo Batista de Sá \\ Andrea Barreto de Paiva
}

\section{1 | INTRODUÇÃO}

Os dispêndios com saúde tem sido objeto de preocupação em quase todos os países. Representavam 3\% do Produto Interno Bruto (PIB) mundial em 1948 e passaram para 8,7\% do PIB em 2004 (OPAS, 2007). No período 1998-2003, a taxa média anual de crescimento dos gastos com saúde (5,7\%) superou a taxa média de crescimento da economia mundial que foi de 3,6\% (HSIAO, 2007).

Nos países desenvolvidos e em desenvolvimento, que já investem parcela considerável do seu PIB no setor, as atenções estão cada vez mais voltadas para a eficiência, efetividade e equidade nos gastos, uma vez que maior nível de dispêndios é condição insuficiente para alcançar melhores condições de saúde (HSIAO, 2007) e nem resolve, por si só, as iniquidades no acesso aos serviços. Nos países mais pobres, por sua vez, é premente a necessidade de estender o acesso aos serviços de saúde, de forma igualitária, a toda população, de melhorar a qualidade do atendimento e de buscar formas de suprir o financiamento setorial em concorrência com outras exigências de desenvolvimento social e econômico (PIOLA et. al., 2008).

Complementando a preocupação com o volume, a eficiência e a efetividade dos gastos com saúde têm sido destacadas como objetivos essenciais para o aperfeiçoamento dos sistemas de financiamento do setor: (i) a proteção financeira contra os riscos do adoecimento 2 ; (ii) a equidade no financiamento ${ }^{3}$; (iii)

1 Este texto serviu de base para seção da publicação "A Saúde no Brasil em 2030 — Diretrizes para a Prospecção Estratégica do Sistema de Saúde Brasileiro", Fundação Oswaldo Cruz. (et. al.). Rio de Janeiro:Fiocruz/IPEA/MS/ SAE/PR, 2012 e para elaboração de artigo publicado da revista Análise Econômico, da Universidade Federal do Rio Grande do Sul.

2 Um sistema de financiamento para a saúde deveria criar proteções contra o risco de empobrecimento relacionado ao uso de serviços de saúde (WAGSTAFF e van DOORSLAER 2003; KUTZIN, 2010).

3 A equidade no financiamento implicaria uma distribuição progressiva ou, pelo menos, proporcional do financiamento com relação à renda (WAGSTAFF et al, 1999). 
a busca, via alocação de recursos, de equidade no acesso e utilização de serviços de saúde ${ }^{4}$.

De maneira geral, nos países desenvolvidos e em desenvolvimento, a maior parte do financiamento da saúde provém de fontes públicas. Nestes países a maior parte do gasto privado é realizada sob a forma de pré-pagamento (planos e seguros privados). O desembolso direto, forma mais iníqua e excludente de financiamento, é, paradoxalmente, maior nos países mais pobres (OMS, 2000)5. Nos países de renda alta, as fontes administradas pelo setor público se responsabilizam, em média, por mais de $60 \%$ do gasto total, enquanto que nos países de renda baixa a participação do setor público não chega a 25\% do dispêndio total (SCHIEBER et. al., 2007).

No Brasil o sistema de saúde é pluralista tanto em termos institucionais ${ }^{6}$ quanto de fontes de financiamento e de modalidades de atenção à saúde. Essa pluralidade se expressa em quatro vias básicas de acesso da população aos serviços de saúde: (i) o Sistema Único de Saúde (SUS), de acesso universal, gratuito e financiado exclusivamente com recursos públicos (impostos e contribuições sociais); (ii) o segmento de planos e seguros privados de saúde, de vinculação eletiva, financiado com recursos das famílias e/ou dos empregadores, composto por 1.174 operadoras de planos de assistência médico-hospitalar e 427de planos exclusivamente odontológicos (BRASIL, ANS, 2012)7; (iii) o segmento de atenção aos servidores públicos, civis e militares e seus dependentes, de acesso restrito a essa clientela, financiado com recursos públicos e dos próprios beneficiários, em geral atendidos na rede privada; (iv) o segmento de provedores privados autônomos de saúde, de acesso direto mediante pagamento no ato (RIBEIRO et al, 2005).

O Brasil, segundo estimativas do Instituto Brasileiro de Geografia e Estatística (IBGE), tinha um dispêndio total (público e privado) em saúde equivalente a 8,8\% do PIB (IBGE, 2012). Esse percentual é baixo quando comparado com o observado nos Estados Unidos (15,7\%), mas é bastante próximo ao de outros países

4 Os modos de financiamento deveriam buscar a equidade na utilização dos serviços (PRADHAN e PRESCOTT, 2002; KUTZIN, 2010). Isso implicaria que os recursos deveriam ser distribuídos de acordo com as necessidades de saúde da população e não de acordo com sua capacidade de pagamento (OMS, 2000; KUTZIN, 2010).

5 Estudos sobre gastos catastróficos em saúde têm demonstrado uma forte associação entre elevada participação do gasto direto do bolso no gasto total em saúde e o percentual de famílias que incorrem em gasto catastrófico (XU et. al., 2005). Estimativas utilizando a POF indicam que o percentual de famílias brasileiras incorrendo em gasto catastrófico seria menor do que aquele obtido utilizando a Pesquisa de Condições de Vida (PPV), provavelmente por aquela ser uma pesquisa que capta melhor os gastos e por ter cobertura nacional. Outra questão é quanto o SUS influencia esse resultado (DINIZ et. al., 2007). Outros estudos comparando países têm mostrado que sistemas de pré-pagamento compulsório (via tributação geral ou seguro de saúde compulsório) tendem a ser mais equitativos que sistema de pré-pagamento voluntário. Os pagamentos diretos do bolso seriam a forma mais regressiva de financiamento (WAGSTAFF et. al., 1999; KUTZIN, 2010).

6 Sua estrutura é composta por entes públicos (federais, estaduais e municipais) e privados (com e sem fins lucrativos).

7 Estas informações referem-se às operadoras em atividade naquele período. 
da Organização para Cooperação e Desenvolvimento Econômico (OCDE), como o Reino Unido (8,4\%), Espanha (8,5\%) e Austrália (8,9\%) que também possuem sistemas universais (WHO, 2010).

O problema do Brasil, se assim pode ser chamado, é que o gasto público é muito baixo para o país ter, efetivamente, um sistema de cobertura universal e atendimento integral. Esse gasto foi estimado em 3,8\% do PIB em 2009 (IBGE, 2012) ${ }^{8}$. Em 2007, o gasto público com saúde foi responsável por 42\% dos recursos aplicados em saúde, enquanto nos países da OCDE, a participação do gasto público no financiamento do sistema representa, em média, 70\% da despesa total ${ }^{9}$.

O subfinanciamento da saúde pública, por um lado, e o excesso de incentivos governamentais para o mercado privado de saúde, por outro, contribuem para que a participação do gasto público com no gasto total com saúde seja menor que o gasto privado, transformando o Brasil no único país com sistema universal de saúde onde o gasto privado supera o público.

Este texto pretende analisar o financiamento público da saúde em aspectos que dizem respeito ao volume destes recursos bem como a forma como esse dinheiro é gasto saúde. Desta forma, a seção 2 faz uma breve discussão sobre o financiamento público da saúde destinado ao setor privado, sob a forma de renúncia fiscal e ressarcimento (ou a falta deste) devido ao SUS por parte do setor privado. Nesta seção, também será discutido de forma mais detalhada o financiamento público destinado a serviços de acesso universal, ou seja, o gasto do SUS. Assim, serão tratadas questões referentes ao volume de recursos que financiam a saúde pública, incluindo o histórico do financiamento da saúde, a evolução do gasto público total, o impacto macroeconômico e fiscal destes recursos, dentre outros. Na seção 3, a ideia é discutir como estes recursos destinados à saúde de acesso gratuito e universal são repartidos, incluindo questões sobre a distribuição regional do gasto, programática e por modalidade de aplicação. Por fim, serão traçados cenários até o ano de 2030 referentes aos gastos públicos com saúde das três esferas.

8 O gasto público estimado na Conta-Satélite pelo IBGE ainda não inclui algumas despesas como: a assistência médica dos servidores civis dos três níveis de governo, com exceção do realizado pelo Ministério da Saúde (MS); os serviços de saúde dos hospitais universitários públicos estadual e municipal; e as "despesas de órgãos vinculados às secretarias de segurança pública e defesa civil (como as redes do sistema penitenciário, de órgãos de defesa civil e de órgãos policiais civil e militar)" (IBGE, 2009b) Com relação à assistência médica a servidores, sua inclusão mais integral nas Contas-Satélites de Saúde (CSS) do Brasil depende da obtenção de informações sobre esses benefícios concedidos pelos órgãos públicos das três esferas de governo.

9 Este percentual varia de variando de 67,5\% (Austrália) a 84,1\% (Noruega). Os Estados Unidos constituem a exceção mais importante a essa regra por ter um gasto privado superior a $50 \%$ do total (OMS, 2008). 


\section{2 | FINANCIAMENTO PÚBLICO DA SAÚDE: UMA DISCUSSÃO SOBRE O VOLUME DE RECURSOS}

O financiamento público é uma das formas pela qual os segmentos que compõem as quatro vias básicas de acesso da população aos serviços de saúde — SUS, planos e seguros privados, assistência a servidores públicos e privados autônomos — se comunicam. No caso do setor público, principalmente em relação aos serviços de acesso universal, esse financiamento ocorre de forma mais direta e preponderante. No setor privado, o financiamento público ocorre de forma indireta, por meio de renúncias fiscais, da utilização de serviços públicos para os quais poderia caber ressarcimento de planos e seguros de saúde e de outros mecanismos de incentivos públicos ao setor privado. As renúncias incluem as isenções concedidas às instituições sem fins lucrativos, as deduções do imposto de renda concedidas às pessoas físicas e jurídicas devido a gastos com médicos, dentistas, laboratórios, hospitais e planos de saúde e a desoneração tributária de determinados medicamentos.

Neste contexto, o tópico a seguir traz uma breve discussão sobre os subsídios públicos destinados ao setor privado. Dando continuidade, serão tratadas de forma mais detalhada e consistente as informações sobre o volume de recursos que financiam a saúde pública, considerando os antecedentes que contribuíram para a atual configuração do financiamento público, bem como a evolução deste montante de recursos.

\subsection{Subsídios Públicos ao Setor Privado: renúncia fiscal e ressarcimento}

A Secretaria da Receita Federal (SRF) estima para 2013 uma renúncia de arrecadação federal de quase $\mathrm{R} \$ 21$ bilhões devido às isenções, deduções e desonerações na área de saúde ${ }^{10}$. Contudo, esse número pode estar subestimado. Em 2010, por exemplo, a renúncia de arrecadação foi de mais de R\$ 16,1 bilhões e o valor estimado era de aproximadamente $\mathrm{R} \$ 12,3$ bilhões.

Como pode ser visto na tabela 1, uma grande parcela do chamado gasto tributário ${ }^{11}$ deve-se a benefícios concedidos por meio do Imposto de Renda (IR) ${ }^{12}$. As

10 http://www.receita.fazenda.gov.br/publico/estudotributario/BensTributarios/2013/DGT2013.pdf. Acesso em 15/02/2013.

11 O gasto tributário é definido pela SRF como a perda de arrecadação devido a desonerações tributárias que se constituam alternativa às ações políticas de governo e tenham por objetivo: i) compensar gastos realizados pelos contribuintes com serviços não atendidos pelo governo; ii) compensar ações complementares às funções típicas de estado desenvolvidas por entidades civis; iii) promover a equalização das rendas entre regiões; e/ ou iv) incentivar determinado setor da economia. As desonerações tributárias são todas e quaisquer situações que promovam: presunções creditícias, isenções, anistias, reduções de alíquotas, deduções, abatimentos e diferimentos de obrigações de natureza tributária (SRF, 2012).

12 A renúncia tributária relacionada a pagamentos feitos diretamente pelos indivíduos aos prestadores de serviços de saúde ou para pagamentos de planos e seguros de saúde não tem a mesma natureza das isenções concedidas 
pessoas jurídicas e as pessoas físicas podem deduzir as despesas com saúde da base de cálculo desse imposto. O gasto tributário nessas duas modalidades para o ano de 2010 foi de algo em torno de $\mathrm{R}$ \$ 2,6 e R \$ 7,8 bilhões respectivamente, totalizando quase $\mathrm{R} \$ 10,4$ bilhões ${ }^{13}$. Este montante de recursos é significativo quando comparado ao gasto direto com ações e serviços públicos de saúde, isto é, o gasto SUS, que foi de aproximadamente $\mathrm{R} \$ 139$ bilhões para esse ano. Vale lembrar que enquanto o gasto SUS beneficia toda a população brasileira, aproximadamente 191 milhões de pessoas em 2010, estes recursos beneficiam apenas os declarantes e seus dependentes que tiveram despesas com saúde relativas ao ano-calendário 2010 dedutíveis do imposto de renda e os empregados e seus dependentes que tiveram planos ou seguros de saúde pagos por seus empregadores no mesmo período.

\section{Tabela 01. Gastos tributários efetivamente realizados — Ano Calendário 2010}

\begin{tabular}{|l|c|r}
\hline \multirow{2}{*}{\multicolumn{1}{c|}{ Modalidade }} & \multicolumn{2}{c}{ (R\$ milhões) } \\
\cline { 2 - 3 } & Tributo & \multicolumn{1}{c}{ Valor } \\
\hline Despesas com Saúde das PF & IRPF & 7.806 \\
\hline Despesas com Saúde das PJ & IRPJ & 2.580 \\
\hline Entidades Sem Fins Lucrativos & IRPJ, CSLL, COFINS & 2.098 \\
\hline Medicamentos & PIS, COFINS & 2.844 \\
\hline Produtos Químicos e Farmacêuticos & PIS, COFINS & 770 \\
\hline Total & & 16.098 \\
\hline
\end{tabular}

Fonte: SRF (2012).

IRPF: Imposto de Renda de Pessoa Física. IRPJ: Imposto de Renda de Pessoa Jurídica. CSLL: Contribuição Social sobre o Lucro Líquido. PIS: Programa de Integração Social. COFINS: Contribuição para o Financiamento da Seguridade Social

A comparação é mais expressiva quando são considerados alguns programas específicos. O gasto tributário via Imposto de Renda Pessoa Física (IRPF)

para medicamentos e para entidades sem fins de lucro (filantrópicas). Essa diferença é relacionada não somente a população beneficiada, mas, também, aos requisitos para sua concessão. A princípio pode-se pensar que os hospitais filantrópicos, por sua obrigatoriedade de atender o SUS, têm um perfil de oferta de serviços e de cobertura populacional mais equitativo. Contudo, seria necessário fazer um estudo sobre os benefícios sociais líquidos dessas isenções (volume de benefícios tributários, perfil da população beneficiada e estimativa dos impactos sociais). Por sua vez, a desoneração tributária sobre medicamentos atinge, indistintamente, a todos os consumidores. Assim, destaca-se a necessidade de estudar melhor cada uma dessas modalidades de gastos tributários relacionados à saúde. A dificuldade para isso tem sido obter dados desagregados para realizar análise mais detalhadas.

13 Em 2012, foi apresentada mudança metodológica no levantamento das estimativas da renúncia fiscal concedida no IRPF. A mudança metodológica consistiu na divisão dos contribuintes por faixas de renda e aplicação da alíquota marginal específica de cada faixa correspondente sobre o valor dos rendimentos isentos e não tributáveis e sobre as deduções do rendimento tributável, enquanto que anteriormente, era aplicada a alíquota média do imposto de renda da pessoa física sobre o total desses valores. Essa mudança implicou em aumento das estimativas da renúncia fiscal concedida no IRPF (SRF, 2012). 
foi superior em quase R $\$ 1,9$ bilhão ao gasto em 2010 com o Piso da Atenção Básica Variável, que financia a estratégia Saúde da Família e foi de aproximadamente R \$ 5,9 bilhões, e em mais de $\mathrm{R} \$ 4$ bilhões ao gasto com o Piso de Atenção Básica Fixo, que foi de $\mathrm{R} \$$ 3,7 bilhões. Isto é, os recursos que deixam de ser arrecadados somente com os descontos concedidos no IRPF superam os recursos alocados para programas do SUS que são críticos para o bom funcionamento do sistema público e devem beneficiar toda a população brasileira e não somente a parcela que usa o sistema privado.

Diversos autores argumentam que a renúncia fiscal termina por beneficiar indiretamente os serviços privados de saúde em geral e as operadoras de planos e seguros de saúde em particular, ao incentivar o consumo dos seus produtos.

A saúde suplementar também se beneficia quando o SUS atende a pacientes que são usuários de planos e seguros de saúde de dois modos: i) quando não há ressarcimento dos custos do atendimento prestado pelo SUS; e, ii) quando há ressarcimento ao SUS usando a Tabela Nacional de Equivalência de Procedimentos - TUNEP ${ }^{14}$. De acordo com o último Caderno de Informação de Ressarcimento e Integração com o SUS (BRASIL, ANS, 2009), entre setembro de 1999 e junho de 2006 foram identificados 992.110 atendimentos hospitalares do SUS prestados aos beneficiários de planos e seguros de saúde ${ }^{15}$. O valor desses atendimentos superou $\mathrm{R} \$$ 1,4 bilhão. Contudo, quase $73 \%$ dos atendimentos identificados tiveram seu pedido de ressarcimento impugnado pelas operadoras. Assim, quando da elaboração do Caderno, apenas 473.540 atendimentos, no valor de aproximadamente $\mathrm{R} \$ 652$ milhões, eram passíveis de ressarcimento e apenas 76.675, no valor de $\mathrm{R} \$$ 97,3 milhões, tinham sido efetivamente ressarcidos. Os demais valores estavam pendentes de decisões administrativas ou judiciais.

O ressarcimento foi instituído pela Lei n 9.656, de 3 de junho de 1998, mas sua implementação encontra resistência por parte das operadoras. Uma das alegações que têm sido utilizadas para não ressarcir o SUS tem sido a garantia constitucional de acesso aos serviços públicos de saúde por todos os brasileiros. O ressarcimento também enfrenta a resistência de alguns críticos que consideram que os valores envolvidos e as dificuldades para o ressarcimento efetivo não superam os custos da estrutura necessária para sua cobrança. Quanto aos valores envolvidos, vale lembrar, que dificuldades administrativas, como a falta de identificação do usuário na maioria dos procedimentos realizados pelo SUS, impedem a ANS de incluir no ressarcimento os demais tipos de atendimento.

14 Como os valores estabelecidos na TUNEP não podem ser superiores à média dos valores praticados na Saúde Suplementar, pode ser vantajoso financeiramente para as operadoras usarem os serviços do SUS.

15 Observe-se que este registro de procedimentos com vistas ao ressarcimento envolve, até o momento, apenas as internações hospitalares. Não estão incluídos atendimentos ambulatoriais. 


\section{2 | Financiamento da Saúde Pública: antecedentes ${ }^{16}$}

No início da década de 1980, a saúde contava com recursos originários de duas fontes: previdência social e orçamento fiscal. Os recursos previdenciários eram destinados, basicamente, para a assistência médico-hospitalar das pessoas que participavam do mercado formal de trabalho, ao passo que os recursos fiscais financiavam as ações típicas de saúde pública (basicamente vigilância, controle de doenças transmissíveis e vacinação) e algumas ações de assistência médica para a população não vinculada ao sistema previdenciário (IPEA, 2009a; VIANNA, 1992). A assistência à saúde para estes últimos dependia em grande parte da ação de entidades filantrópicas. Os dois orçamentos, historicamente, tiveram participação bastante desigual no gasto federal com saúde: "Entre 1980 e 1986 o Tesouro teve participação relativa crescente, embora nunca superior a 32,1\%, caindo em 1987 para 27,1\%" (VIANNA, 1992). Assim, conviviam dois sistemas com coberturas muito diferenciadas tanto em termos do tipo de assistência à saúde prestada à população quanto no que se refere ao seu financiamento.

Além disso, a participação estimada de cada ente da federação no financiamento era muito desigual. Segundo estimativas de Barros, Piola e Vianna (1996), em 1980, a União respondia por 75\% das despesas com saúde, enquanto os estados respondiam por $17,8 \%$ e os municípios por $7,2 \%$.

A CF/88, ao criar a Seguridade Social, estabeleceu que ela deveria ser financiada com recursos provenientes dos orçamentos da União, dos estados, do Distrito Federal e dos municípios e de contribuições sociais. Esses recursos, no âmbito do Governo Federal, seriam divididos entre a Previdência, a Assistência Social e a Saúde, e, no caso desta última, previu-se, conforme consta do artigo 55 do Ato das Disposições Constitucionais Transitórias (ADCT), uma vinculação de 30\% dos recursos do Orçamento da Seguridade Social (OSS), excluído o seguro-desemprego, até que fosse aprovada a primeira Lei de Diretrizes Orçamentárias (LDO). Essa lei deveria definir a cada ano qual o percentual a ser destinado à saúde.

Segundo Vianna (1992), o percentual de 30\% não foi cumprido em 1990 e 1991. No ano seguinte, diz que só foi possível cumpri-lo porque foram contabilizadas ações de saneamento básico, apoio nutricional, saúde do trabalhador, merenda, encargos com inativos e pensionistas do MS, entre outras, como parte do orçamento da saúde.

Em 1993, as contribuições previdenciárias deixaram de ser consideradas solidárias ao financiamento da saúde. Nesse ano, apesar da previsão de recursos para a saúde, nada foi repassado com base na alegação de problemas de caixa na Previdência. Esse fato agravou a situação de incerteza e de instabilidade do financiamento da saúde (MENDES; MARQUES, 2009).

16 Este item é uma versão atualizada do constante em Servo et al (2011). 
Adicionalmente, ainda que a CF/88 também estabelecesse que parte das receitas de estados e municípios devesse ser aplicada em saúde, ela não estabelecia um percentual mínimo de aplicação. Assim, nos primeiros anos após a promulgação da CF 88, estima-se que a maior parte dos recursos públicos destinados para o SUS estava concentrada no nível federal (BARROS, PIOLA e VIANNA, 1996).

Na busca por recursos, a saúde recorreu inclusive a empréstimos do Fundo de Amparo ao Trabalhador (FAT). Essa situação emergencial levou à necessidade de se pensar em alternativa para a superação da crise de carência de recursos, a qual pareceu apresentar-se na forma da Contribuição Provisória sobre Movimentação Financeira (CPMF), criada em $1996^{17}$ (Lei 9.311, de 24 de outubro de 1996).

A CPMF surge com o acréscimo do art. 74 ao Ato das Disposições Constitucionais Transitórias (Emenda Constitucional n 12, de 15/08/1996), que permitiu à União instituir esse tipo de contribuição. A fundamentação para sua cobrança foi a necessidade de financiamento da Seguridade Social, mais especificamente da área de saúde. A previsão legal era que o produto de sua arrecadação seria integralmente destinado ao Fundo Nacional de Saúde, para financiamento de ações e serviços de saúde (artigo 18, da Lei 9.311, de 24 de outubro de 1996).

Inicialmente vigorando como percentual de 0,20\% sobre movimentações financeiras, em junho de $1999^{18}$, a CPMF foi prorrogada até 2002, com alíquota de 0,38\%. Tal elevação teve como justificativa prover recursos para a Previdência Social. Em 2002 a CPMF foi prorrogada, o que ocorreu novamente em 2004, tendo vigorado até dezembro de 2007.

Ao entrar em vigor, a CPMF passou a ser uma das principais fontes de financiamento do MS. Em 1997 já respondia por 27,8\% do total de recursos, tendo alcançado 38,4\% em 2002 e daí por diante, até 2007, mantendo-se em torno de 30\%. Em média, no período entre 1997 e 2007, a CPMF respondeu por 1/3 do total dos recursos do MS (SERVO et al, 2011).

O caráter provisório da CPMF sempre preocupou os gestores da saúde, que continuaram trabalhando por solução mais abrangente e definitiva. No legislativo diversas propostas foram apresentadas. O ponto em comum entre elas era a busca pela vinculação para a saúde dos recursos orçamentários dos três níveis de governo.

17 A CPMF surge como herdeira do antigo Imposto Provisório sobre Movimentação Financeira (IPMF), que foi instituído em 1993 com previsão para vigorar até 1994, quando foi extinto. Esse imposto não tinha vinculação com a saúde, mas abriu espaço para a criação da CPMF.

18 Os aumentos da CPMF também trouxeram o compartilhamento de recursos com outras áreas. O recurso que inicialmente era destinado somente para a área de saúde, a partir de 1999 passou a ser destinado também à previdência e, em 2001, ao Fundo de Combate à Pobreza. Particularmente a partir de 2001, manteve-se a arrecadação de 0,20\% para a saúde e os recursos adicionais foram destinados a outros setores sociais. 
Várias propostas de vinculação de recursos para a saúde começaram a tramitar ${ }^{19}$ no Congresso Nacional, algumas delas anteriores a própria criação da CPMF, como a Proposta de Emenda à Constituição (PEC) 169-A, encaminhada ainda em 1993. Essa proposta foi sendo alterada e aglutinada a outras iniciativas de lei mencionadas a seguir. A PEC 169-A trazia a proposta de alteração do artigo 198 da Constituição Federal que teria a seguinte redação:

A União aplicará anualmente, na implementação do Sistema Único de Saúde, nunca menos de trinta por cento das receitas de contribuições sociais que compõem o Orçamento da Seguridade Social e dez por cento da receita resultante dos impostos. [...] Os Estados, o DF e os municípios aplicarão anualmente, na implementação do Sistema Único de Saúde, nunca menos de $10 \%$ das receitas resultantes dos impostos.

Ao longo desse processo destacam-se outras propostas como a $\mathrm{PEC}^{20}$ que propunha destinar recursos equivalentes sempre a 5\% do PIB do ano anterior para o financiamento da saúde e a PEC 82-A, que determinava que os recursos da e da CSLL fossem destinados integralmente à saúde, assegurando também um patamar mínimo de recursos por parte dos outros entes federados (MARQUES; MENDES, 1999 apud CONASS, 2007).

Nesse mesmo ano de 1998, a Comissão Especial que avaliou a PEC 82-A, tendo como relator o Deputado Urcisino Queiroz (BA), elaborou substitutivo que compatibilizou aspectos das propostas dos deputados Carlos Mosconi, Eduardo Jorge e outros. Após intensas negociações foi aprovada pela Câmara, em votação de dois turnos, como a PEC n. 82-C. Essa proposta tramitou no Senado como PEC 86-A e acabou sendo aprovada e promulgada como Emenda Constitucional n. 29. (CONASS, 2007, p. 31)

A Emenda Constitucional 29 (EC 29) assegurou a participação das três esferas de governo no financiamento das ações e dos serviços públicos de saúde, a partir da definição de um aporte anual mínimo de recursos. No caso da União, os recursos a serem aplicados em 2000 corresponderiam ao montante empenhado no exercício de

19 “A vinculação de recursos para o SUS não é pretensão recente. Já constava da proposta da Comissão Nacional da Reforma Sanitária (CNRS) criada, em 1986, por recomendação da VIII CNS. A CNRS pretendia vincular à saúde recursos equivalentes a 10\% do PIB (WHO, 2003). Em valores atuais (2005) esse percentual representaria cerca de R\$193,7 bilhões, um valor em torno de 37\% das receitas das três esferas governo." (CONASS, 2007, p. 29). 
1999 acrescido de, no mínimo, 5\%. A partir daí, o valor mínimo seria apurado no ano anterior e corrigido pela variação nominal do PIB, regra esta que permaneceu valendo com a regulamentação da EC-29 pela Lei Complementar 141/2012. Os estados e o Distrito Federal deveriam aplicar, no mínimo, 12\% da receita vinculada ${ }^{21}$; ao passo que os municípios deveriam aplicar 15\%, e, em 2000, o percentual mínimo a ser aplicado seria de 7\% para esses entes da federação. (RIBEIRO; PIOLA; SERVO, 2005; CONASS, 2007).

Observa-se que o fim da CPMF, em 2007, não gerou uma crise nas mesmas proporções daquela observada em 1993, quando o Ministério da Saúde foi buscar recursos de empréstimos via FAT. Aparentemente, a vinculação de recursos da EC 29 garantiu um mínimo de estabilidade no financiamento da saúde e, pode-se dizer, trouxe aumento, sobretudo a partir de 2004, no aporte de recursos por parte da União (SERVO et al, 2011). De qualquer forma, parte significativa do aumento de recursos para o SUS, como decorrência da EC 29, veio da ampliação da participação de estados e municípios no financiamento do SUS (BIASOTO JR., 2003, entre outros), como será discutido a seguir.

\subsection{Evolução do gasto público total: efeitos da EC 29 de 2000}

A aprovação da EC 29 teve impactos diferenciados em cada ente da Federação. Segundo estimativas de Piola e Vianna (1992, apud BARROS, PIOLA e VIANNA, 1996), durante a década de 80, a União participava, em média, com 75\% dos recursos públicos alocados em saúde. Outra estimativa do IPEA para o ano de 1996 indica que a União respondia por 63\% do total, os estados, 20,7\%, e os municípios, 16,4\% (FERNANDES et al, 1998)22. A EC 29 começou a ter vigência em 2000, quando a União ainda respondia por quase $60 \%$ do recurso público total aplicado em saúde. Desde então sua participação foi decrescendo, para alcançar cerca de 45\% em 2011. Nesse mesmo período, entre 2000 e 2011, a participação dos estados passou de 18,5\% para $25,7 \%$, enquanto a dos municípios saiu de $21,7 \%$ para $29,6 \%$, de acordo com os dados do SIOPS (ver Tabela 2).

21 A receita vinculada refere-se à base de cálculo para aplicação mínima dos recursos em saúde. A base de cálculo dos estados compreende as receitas de impostos estaduais (ICMS, IPVA, ITCMD), as receitas de transferência da União (FPE, IPI, Lei Kandir), o Imposto de Renda Retido na Fonte (IRRF), outras receitas correntes (receita da dívida tributária de impostos, multas, juros de mora e correção monetária) e exclui as transferências constitucionais e legais a municípios (ICMS, IPVA e IPI — exportação). A base de cálculo dos municípios abrange as receitas de impostos municipais (ISS, IPTU, ITBI), as receitas de transferências da União (FPM, ITR, Lei Kandir), o Imposto de Renda Retido na Fonte (IRRF), as receitas de transferências do estado (ICMS, IPVA, IPI — exportação) e outras receitas correntes (receita da dívida tributária de impostos, multas, juros de mora e correção monetária).

22 Existem diferenças entre as metodologias e as bases de dados utilizadas pelo IPEA nos anos 1990 e pelo SIOPS a partir da EC 29. Entre outras, a análise feita pelo IPEA refere-se ao gasto funcional, ao passo que as análises feitas pelo SIOPS referem-se ao gasto com "ações e serviços públicos de saúde", conforme definido na Resolução 322 do Conselho Nacional de Saúde, com respeito ao que deve ser considerado para efeitos de cumprimento da EC29. Com isso as informações não são efetivamente comparáveis, porém, isso não impossibilita que sejam utilizadas para analisar tendências. 
Tabela 02. Gasto das Três Esferas com Ações e Serviços Públicos em Saúde 2000 a 2011

\begin{tabular}{c|c|c|c|c|c|c|c}
\hline \multirow{2}{*}{ Ano } & \multicolumn{6}{|c|}{ ESFERA } & \multirow{2}{*}{ Total } \\
\cline { 2 - 7 } & Federal & $\%$ no Total & Estadual & $\%$ no Total & Municipal & $\%$ no Total & \\
\hline 2000 & 41,31 & $59,8 \%$ & 12,82 & $18,5 \%$ & 14,96 & $21,7 \%$ & 69,09 \\
\hline 2001 & 42,70 & $56,1 \%$ & 15,71 & $20,7 \%$ & 17,65 & $23,2 \%$ & 76,07 \\
\hline 2002 & 43,34 & $52,8 \%$ & 17,66 & $21,5 \%$ & 21,08 & $25,7 \%$ & 82,07 \\
\hline 2003 & 41,51 & $51,1 \%$ & 18,67 & $23,0 \%$ & 21,02 & $25,9 \%$ & 81,20 \\
\hline 2004 & 46,85 & $50,2 \%$ & 22,96 & $24,6 \%$ & 23,51 & $25,2 \%$ & 93,33 \\
\hline 2005 & 49,80 & $49,7 \%$ & 23,11 & $23,1 \%$ & 27,19 & $27,2 \%$ & 100,10 \\
\hline 2006 & 52,44 & $48,4 \%$ & 25,48 & $23,5 \%$ & 30,37 & $28,0 \%$ & 108,28 \\
\hline 2007 & 55,01 & $47,5 \%$ & 28,02 & $24,2 \%$ & 32,81 & $28,3 \%$ & 115,84 \\
\hline 2008 & 57,18 & $44,2 \%$ & 32,81 & $25,4 \%$ & 39,24 & $30,4 \%$ & 129,23 \\
\hline 2009 & 65,27 & $45,8 \%$ & 36,13 & $25,4 \%$ & 40,98 & $28,8 \%$ & 142,38 \\
\hline 2010 & 66,08 & $44,1 \%$ & 39,74 & $26,5 \%$ & 44,08 & $29,4 \%$ & 149,90 \\
\hline 2011 & 72,33 & $44,7 \%$ & 41,50 & $25,7 \%$ & 47,94 & $29,6 \%$ & 161,77 \\
\hline
\end{tabular}

Fonte: SPO/MS (Esfera Federal) e SIOPS (Esferas Estaduais e Municipais - extraídos em 13 de junho de 2011).

Notas:

(1) O Gasto Federal ASPS está de acordo com a definição das LDOs, que considera os gastos totais do MS, excetuando-se as despesas com Inativos e Pensionistas, Juros e Amortizações de Dívida, bem como as despesas financiadas pelo Fundo de Combate e Erradicação da Pobreza. Vale lembrar que a SPO, para o cálculo do Gasto Federal ASPS, também considera os valores executados na UO $74202-$ Recursos sob supervisão da ANS até 2007. A partir de 2008, a SPO começou a excluir esta UO do cômputo de gasto em ASPS.

(2) O Gasto Estadual ASPS foi extraído de Notas Técnicas produzidas pelo SIOPS com a análise dos balanços estaduais (2000 a 2008). Foram utilizadas as informações sobre despesa própria da análise dos balanços estaduais efetuada pela equipe do SIOPS, em conformidade com as diretrizes da resolução CNS 322/03 e EC 29/00. Em 2009 e 2010, foram utilizados os dados dos 27 estados que transmitiram ao SIOPS (posição 27 de novembro de 2012). Em 2011, foram utilizadas as informações das 26 UFs que transmitiram até dia 27 de novembro de 2012. Em relação a Alagoas, que ainda não havia transmitido até esta data, atualizou-se a informação de 2010 baseado no crescimento anual médio observado nos últimos 2 anos. Aguardamos a análise de balanço dos respectivos anos para a atualização final deste gasto.

(3) O Gasto Municipal ASPS foi extraído da base do SIOPS em 27 de novembro 2012. Os dados referem-se apenas aos municípios que transmitiram em cada ano, que corresponde a uma média de $99 \%$ do total de municípios entre 2001 e 2010 . Em 2000, $96 \%$ transmitiram os dados ao SIOPS e em 2011este percentual foi de $98 \%$.

* Dados preliminares. Sujeitos à revisão após a análise de balanço.

Esse aumento da participação de estados e municípios no financiamento da saúde implicou, na prática, num incremento real de recursos para saúde da ordem de $R$ \$ 61,6 bilhões. A participação dessas instâncias de governo no financiamento do SUS passou de $R \$ 27,7$ bilhões em 2000 para $R \$ 89,4$ bilhões em 2011. Como resultado desse aporte de recursos, juntamente com o aumento de $\mathrm{R} \$ 31$ bilhões de recursos da União no mesmo período, o gasto público com saúde saiu de $\mathrm{R} \$ 69$ bilhões em 2000 para $\mathrm{R} \$ 161,7$ bilhões em 2011, em termos reais. Assim, dois terços do aumento 
de recursos para ASPS, no período entre 2000 e 2011, foram provenientes de receitas próprias de estados e municípios, enquanto um terço foi alocado pela União. Ou seja, a EC-29, com o aumento da participação de estado e municípios, e crescimento das aplicações da União, possibilitaram o incremento real de 134\% de recursos públicos para a saúde, conforme demonstrado na Tabela 2.

Como desdobramento dessa situação, o gasto per capita das três esferas com o SUS dobrou entre 2000 e 2011, passando de R\$ 403 em 2000 para R\$ 830 em 2011. Em relação ao PIB, o gasto do SUS passou de 2,9\%, em 2000, para 3,9\% em 2011 (Tabela 3), ou seja, um crescimento de um ponto percentual no indicador.

Tabela 03. Gasto Público das Três Esferas com Ações e Serviços Públicos em Saúde como proporção do PIB e per capita — 2000 a 2011

\begin{tabular}{c|c|c|c|c}
\hline \multirow{2}{*}{ Ano } & \multirow{2}{*}{$\begin{array}{c}\text { Participação } \\
\text { (\%) ASPS / PIB }\end{array}$} & \multicolumn{3}{|c}{ Gasto ASPS per capita em R\$ de 2011) } \\
\cline { 4 - 5 } & & $\begin{array}{c}\text { Tx crescimento } \\
\text { real anual }\end{array}$ & $\begin{array}{c}\text { Tx crescimento real } \\
\text { relação a 2000 }\end{array}$ \\
\hline 2000 & $2,9 \%$ & 403,38 & & $8,49 \%$ \\
\hline 2001 & $3,1 \%$ & 437,64 & $8,49 \%$ & $15,10 \%$ \\
\hline 2002 & $3,2 \%$ & 465,51 & $6,37 \%$ & $12,63 \%$ \\
\hline 2003 & $3,1 \%$ & 454,31 & $-2,41 \%$ & $27,75 \%$ \\
\hline 2004 & $3,4 \%$ & 515,32 & $13,43 \%$ & $35,32 \%$ \\
\hline 2005 & $3,5 \%$ & 545,85 & $5,92 \%$ & $44,66 \%$ \\
\hline 2006 & $3,6 \%$ & 583,51 & $6,90 \%$ & $53,04 \%$ \\
\hline 2007 & $3,5 \%$ & 617,32 & $5,79 \%$ & $69,97 \%$ \\
\hline 2008 & $3,6 \%$ & 681,57 & $10,41 \%$ & $84,34 \%$ \\
\hline 2009 & $3,9 \%$ & 743,58 & $9,10 \%$ & $92,29 \%$ \\
\hline 2010 & $3,7 \%$ & 775,66 & $4,31 \%$ & $105,74 \%$ \\
\hline 2011 & $3,9 \%$ & 829,90 & $6,99 \%$ & \\
\hline
\end{tabular}

Fonte: SPO/MS (Esfera Federal) e SIOPS/MS (Esferas Estadual e Municipal - extraídos em 13 de junho de 2011) para gastos em ASPS. IBGE para população (revisão 2008) e PIB.

Notas: O gasto per capita foi atualizado para valores de 2011, segundo IPCA médio anual.

Contudo o aporte de recursos poderia ter sido ainda maior, caso a União e os estados cumprissem a EC 29 de acordo com os critérios previstos na Resolução 322 do CNS. O Governo Federal e os governos estaduais utilizaram diversos expedientes para aplicar menos do que o previsto na Emenda ${ }^{23}$. A equipe da Câmara Técnica do

23 A discussão dessa questão já foi feita à exaustão por vários autores como IPEA (2000 a 2003), Ribeiro, Piola e Servo (2006), SIOPS (2005), entre outros. Apesar de o Conselho Nacional de Saúde ter publicado, como dito, a Resolução 322, tentando normatizar o que se entende por ASPS, ainda há controvérsias sobre diversas questões. 
Sistema de Informações sobre Orçamento Público em Saúde (SIOPS) e o Ministério Público Federal (2009), seguindo a Resolução no 322 do CNS, demonstraram que, em determinados anos, a União e parte dos estados e municípios não teriam aplicado o mínimo exigido pela EC29. No caso dos estados, as análises de balanço feitas pela equipe do SIOPS indicaram que em 2006, em média, a aplicação alcançou 9,6\% da receita vinculada, quando deveria ser no mínimo de $12 \%$ e que, nesse mesmo ano, apenas 16 estados teriam inequivocamente cumprido a Emenda (SIOPS, 2011).

A estimativa de déficit de aplicação dos Estados - quando os valores empenhados em ações e serviços públicos de saúde (SUS) não alcançam os 12\% da receita desses entes da federação - atingiu cerca de R 6 bilhões no período 2004 a 2008, com base nos dados declarados ao SIOPS (antes da verificação baseada na análise dos balanços). Depois da análise, para ver se as aplicações estão de acordo com o estabelecido na Resolução 322 do CNS, o déficit sobe para R\$ 16 bilhões, no período.

Em 2008, último ano com análise de balanço divulgada, o déficit de aplicação dos estados foi de aproximadamente R \$ 3,0 bilhões, de acordo com análise dos balanços dos estados e do DF realizada pela equipe do Siops. Treze estados apresentaram déficit de aplicação em 2008: MA, PI, CE, PB, AL, MG, ES, RJ, PR, SC, RS, MT e GO. Do total do déficit, R\$1,7 bi correspondia aos estados do RS e MG.

Ainda segundo dados da Câmara Técnica do SIOPS, no período 2000 a 2008, o déficit de aplicação do Ministério da Saúde foi estimado em R\$ 3,08 bilhões ${ }^{24}$. O chamado déficit de aplicação representa o somatório da diferença entre valor mínimo a ser aplicado a cada ano, de acordo com os critérios da Emenda, e valor empenhado pelo MS, ou seja, sem compensação dos valores aplicados acima do piso em alguns anos. Se a compensação for feita, o déficit fica em $\mathrm{R} \$ 1,8$ bilhão.

Além dessa "perda" para o SUS, ainda existiam outros vazamentos. Todo ano, parte dos valores empenhados passa para ser paga nos anos seguintes. São os chamados restos a pagar. Esses valores, que constaram como gasto realizado para fins de cumprimento da EC 29 podem, eventualmente, serem cancelados. Só o MS cancelou $\mathrm{R} \$ 2,6$ bilhões dos restos a pagar do SUS de 2000 a 2008 (SIOPS, 2011). Esse procedimento, lançamento de despesas como restos a pagar e posterior cancelamento de parte, também ocorre nas contas do SUS de estados, DF e municípios, mas não há informação sobre os montantes de recursos envolvidos nesse procedimento. O lançamento de despesas como restos a pagar e seu posterior cancelamento por motivos justificados é um procedimento normal/legal da administração pública. A questão é em que proporção isso ocorre e se isso era utilizado para cumprir a vinculação só no papel.

24 Valor correspondente à diferença entre o valor mínimo previsto pela Emenda para cada um dos anos do período de 2000 a 2008 e gasto total do MS, quando são retiradas do gasto total as despesas com inativos e pensionistas e o pagamento de encargos da dívida, que não são, reconhecidamente, despesas com ações e serviços públicos de saúde. 
Por fim, ao se analisar as aplicações do MS tendo como critério a compatibilidade com o conceito de ações e serviços públicos de saúde, que está na Resolução 322 do Conselho Nacional de Saúde, de 3 de maio de 2003, foram encontradas despesas que não poderiam ser incluídas. Entre outras, deveriam ser retirados os gastos com assistência médica a servidores — mais de R \$ 1,0 bi de 2000 a 2008 — (por que não são serviços de acesso universal), com a bolsa alimentação — R \$ 3,2 bi — (transferência monetária que foi executada na conta do MS em 2001 e 2003) e farmácia popular — R \$ 1,8 bi. Ou seja, mais de $\mathrm{R}$ \$ 6,0 bilhões.

Estas estimativas de "vazamentos" podem ser contestadas, mas a apresentação serviu e serve para estimular a discussão. Estas análises, que foram feitas com base na interpretação da legislação e dos instrumentos normativos existentes e foram apresentadas e discutidas na Câmara Técnica do Siops, não chegaram a serem publicadas.

Com a emenda regulamentada por meio da Lei Complementar $\mathrm{n}^{\circ}$ 141/2012, estes vazamentos tendem a diminuir, uma vez que ficou definitivamente explícito, por meio de instrumento adequado, o que são consideradas como ações e serviços públicos de saúde para fins de cumprimento da emenda constitucional. Além disso, em relação aos restos a pagar cancelados (outra fonte de vazamentos), a LC 141/2012 define que os recursos cancelados que entraram na conta para se alcançar o valor mínimo devem ser repostos e como isso deve ser feito. Por fim, a Lei Complementar também se mostrou presente no que tange à regulamentação do não cumprimento do mínimo em saúde previsto em lei: ficou definido que aqueles entes que descumprirem o valor mínimo previsto para ser gasto em ações e serviços públicos de saúde daquele ano deverão compensar esta diferença no ano seguinte, sem que esta diferença entre na contabilidade do valor gasto nesse ano.

\subsection{Gasto em ASPS x Receita nas Três Instâncias de Governo}

Como visto anteriormente, a EC 29 estabeleceu critérios diferentes para as três esferas no que concerne a aplicação mínima de gastos em ASPS. Para a União, o cálculo foi atrelado à variação do PIB, enquanto para estados e municípios, este indicador foi vinculado às suas receitas próprias.

Uma análise interessante do "esforço" empreendido por estes entes federativos ao longo dos últimos anos em relação ao gasto em ASPS seria a proporção deste gasto em relação à receita corrente líquida, que nada mais é que a Receita Corrente Bruta (RCB) 25 descontadas, entre outros, as transferências legais e constitucionais e as contribuições previdenciárias e para o PIS/PASEP. Entretanto, esses dados só estão

25 A Receita Corrente Bruta inclui não só a arrecadação de tributos e contribuições, como as transferências legais e constitucionais e outras receitas correntes (de serviços, patrimonial etc.) 
disponíveis para a União (todo o período) e Estados (2005 a 2011). As informações para municípios só estão disponíveis em relatórios individuais (RREO), mas não para todos os municípios ${ }^{26}$.

Como alternativa, podemos utilizar diferentes medidas de receita ${ }^{27}$. Piola et. al. (no prelo) faz esta análise considerando, no denominador, o numerador da Carga Tributária Bruta (NCTB), a Receita Corrente Bruta (RCB) e a RCB descontadas as transferências para assistência e previdência social (TAPS).

A Carga Tributária Bruta ${ }^{28}$ mede a razão entre o volume de impostos, taxas e contribuições sociais, que são usadas no financiamento das políticas públicas, e o PIB. Neste trabalho, usamos o numerador desta razão no cálculo da medida de esforço descrita na segunda, terceira e quarta colunas da tabela 4. A participação do gasto em saúde no total das receitas tributárias da União (incluídas as contribuições) oscilou entre 7\% e 8\%, entre 2002 e 2011. Nesse mesmo período, houve um aumento da participação dos gastos em saúde dos Estados e Municípios em relação a essa receita.

A Receita Corrente Bruta (RCB) inclui não só a arrecadação de tributos e contribuições, como as transferências legais e constitucionais e outras receitas correntes (de serviços, patrimonial etc.). Recorrentemente, esse indicador é utilizado em discursos a favor da ampliação da participação da União no financiamento da saúde ${ }^{29}$ (tabela 4). Assim, faz sentido comparar União, estados e municípios utilizando essa mesma base.

Ao se analisar a participação do gasto com saúde em relação à Receita Corrente Bruta - RCB percebe-se uma redução significativa na participação municipal quando comparada ao indicador de gasto sobre NCTB. As transferências intergovernamentais (constitucionais/legais e voluntárias) ampliam a receita dos estados e, principalmente, a dos municípios. Essa seria a explicação para a redução da participação desses entes (aumento do denominador). Como a União praticamente não recebe de outros entes, o efeito de uma participação um pouco menor em relação ao indicador de NCTB refere-se às outras receitas (serviços, patrimonial etc.). Esse indicador mostra, também, a dependência dos municípios de recursos que são arrecadados por outros entes, particularmente pela União, fato resultante da estrutura

26 Seria necessário desenvolver uma metodologia para calcular os dados de municípios para todo o período e de estados, tentando retornar, pelo menos, até 2002, a partir de informações disponíveis nos sistemas orçamentários estaduais e municipais da Secretaria do Tesouro Nacional (STN).

27 Obviamente, para possibilitar a comparação do "esforço" realizado pelos três entes, a receita considerada no cálculo deverá ter a mesma metodologia.

28 A Carga Tributária Bruta é o quociente entre o somatório das arrecadações de impostos, taxas e contribuições pelas três esferas de governo (federal, estadual e municipal) e o Produto Interno Bruto, segundo IBGE (2008).

$29 \mathrm{Na}$ verdade, uma das principais reivindicações da bancada sanitarista na regulamentação da EC-29 era a de que o gasto mínimo em ASPS da União correspondesse a 10\% da RCB. Entretanto, a Lei 141/2012 manteve a forma de cálculo atual: o valor mínimo a ser aplicado em ASPS será atrelado à variação nominal do PIB. 
tributária e do sistema federativo brasileiro. No caso desse indicador, o percentual da RCB aplicada pela União e pelos Estados tende a se aproximar ao longo dos anos. O percentual comprometido pelos municípios é maior que aquele dos outros entes.

Tabela 04. Participação do Gasto com Ações e Serviços a Públicos de Saúde (ASPS) na Carga Tributária Bruta (nCTB), na Receita Corrente Bruta e na Receita Corrente Bruta descontadas as transferências assistenciais, previdenciárias e os subsídios (TAPS), 2002 a 2011

\begin{tabular}{c|c|c|c|c|c|c|c|c|c|}
\hline \multirow{2}{*}{ Ano } & \multicolumn{3}{|c|}{$\%$ da nCTB } & \multicolumn{3}{c|}{$\%$ da RCB } & \multicolumn{3}{c}{$\%$ da RCB - TAPS } \\
\cline { 2 - 11 } & União & Estados & Municípios & União & Estados & Municípios & União & Estados & Municípios \\
\hline 2002 & $7,7 \%$ & $7,8 \%$ & $48,3 \%$ & $7,2 \%$ & $5,4 \%$ & $10,9 \%$ & $14,0 \%$ & $6,5 \%$ & $11,8 \%$ \\
\hline 2003 & $7,5 \%$ & $8,2 \%$ & $47,1 \%$ & $7,1 \%$ & $5,8 \%$ & $11,1 \%$ & $14,8 \%$ & $7,0 \%$ & $12,0 \%$ \\
\hline 2004 & $7,7 \%$ & $9,2 \%$ & $47,4 \%$ & $7,3 \%$ & $6,5 \%$ & $11,3 \%$ & $14,6 \%$ & $7,8 \%$ & $12,2 \%$ \\
\hline 2005 & $7,5 \%$ & $8,9 \%$ & $52,6 \%$ & $7,0 \%$ & $6,1 \%$ & $12,2 \%$ & $13,8 \%$ & $7,3 \%$ & $13,0 \%$ \\
\hline 2006 & $7,5 \%$ & $9,2 \%$ & $53,3 \%$ & $7,0 \%$ & $6,4 \%$ & $12,4 \%$ & $13,9 \%$ & $7,6 \%$ & $13,2 \%$ \\
\hline 2007 & $7,1 \%$ & $9,4 \%$ & $51,6 \%$ & $6,7 \%$ & $6,5 \%$ & $12,3 \%$ & $13,4 \%$ & $7,7 \%$ & $13,1 \%$ \\
\hline 2008 & $6,9 \%$ & $10,0 \%$ & $56,9 \%$ & $6,4 \%$ & $6,8 \%$ & $13,2 \%$ & $12,4 \%$ & $7,7 \%$ & $14,1 \%$ \\
\hline 2009 & $8,0 \%$ & $11,2 \%$ & $57,4 \%$ & $7,5 \%$ & $7,6 \%$ & $13,2 \%$ & $16,1 \%$ & $9,0 \%$ & $14,1 \%$ \\
\hline 2010 & $7,3 \%$ & $11,0 \%$ & $55,0 \%$ & $7,0 \%$ & $7,6 \%$ & $13,0 \%$ & $14,5 \%$ & $8,9 \%$ & $14,1 \%$ \\
\hline 2011 & $7,2 \%$ & $11,0 \%$ & $54,7 \%$ & $7,0 \%$ & $7,5 \%$ & $13,5 \%$ & $14,0 \%$ & $9,0 \%$ & $14,7 \%$ \\
\hline
\end{tabular}

Fonte: Secretaria de Tesouro Nacional/Ministério da fazenda (Receita Corrente Bruta e Receita Corrente Líquida); Secretaria de Política Econômica/Ministério da Fazenda. (Transferências para Assistência e Previdência Social — TAPS); Orair (2012) — numerador da Carga Tributária Bruta; SIOPS/MS e SPO/MS (gasto em ASPS). Elaboração dos autores.

Nota: Dados de RCB dos municípios são provenientes do Finbra e referem-se, em média, a 5.300 municípios (95\% do total de municípios).

O terceiro indicador seria composto, no denominador, pela RCB descontadas as TAPS. A ideia subjacente a esse indicador é que, como os benefícios previdenciários representam em torno de 15\% do PIB e são de pagamento obrigatório, ao excluí-los ter-se-ia uma primeira aproximação para disponibilidade de recursos, já que não temos informações sobre a RCL para os três entes. Como a responsabilidade pelo pagamento desses benefícios é maior para União, quando eles são descontados observa-se uma aproximação, ao longo do tempo, do indicador no nível municipal em relação ao indicador federal. Ao final do período, ambos estavam comprometendo 14\% da sua RCB descontados as TAPS.

Esses indicadores mostram diferentes aspectos relacionados ao comprometimento dos entes federativos com gastos em saúde. A análise mostra um aumento do esforço relativo dos municípios ao longo do tempo, independentemente 
dos indicadores. Contudo, a depender do indicador utilizado, no final do período houve uma convergência da proporção aplicada. Quando usamos a RCB, há uma convergência dos indicadores entre União e Estados e quando usamos RCB excluídas as TAPS, há uma aproximação entre União e municípios.

Entretanto, apesar do aumento relativo do esforço de estados e municípios, o percentual de recursos públicos aplicados em saúde não ultrapassou 4\% do PIB (tabela 3). Um percentual abaixo do praticado em países com sistemas de saúde universal, que já ultrapassa os 6\% do PIB há algum tempo e, em muitos, supera 10\%. Essas comparações dão uma ideia do caminho que o Brasil ainda tem que percorrer, sendo necessário avançar, também, na compreensão do custo e da efetiva necessidade de recursos para implantar um sistema que se quer universal, integral e equânime.

\subsection{O Impacto do Gasto Federal em Saúde no Gasto Social Federal (GSF)}

Outra forma possível de analisar o volume de recursos conquistados pela saúde ao longo dos últimos anos é sua representação no Gasto Social Federal (GSF) ${ }^{30}$. Entretanto, esta análise refere-se apenas à esfera federal.

A série de gastos elaborada pela DISOC/IPEA demonstra que tem havido um aumento quase constante da participação relativa do GSF no PIB. No período de 1995 a 2010 o aumento foi de quase quatro pontos percentuais, fazendo com que o GSF saísse do patamar de $11,2 \%$ para $15,5 \%$ do PIB.

Dentre as áreas que compõem a conta do GSF, elaborada pela DISOC/ IPEA, a Previdência Social é a de maior representatividade em relação ao PIB, tendo aumentado sua participação de 5\% em 1995 para 7,4\% em 2010. A Assistência Social se destaca pelo seu comportamento ascendente no período, apesar de representar uma fatia pequena do PIB (de 0,1\% a 1,1\%). As áreas de Saúde e Benefícios a Servidores apresentaram um comportamento estável ao longo do período, representando, em média, 1,7\% e 2,4\% do PIB respectivamente (Gráfico 1).

Apresentando comportamento estável em relação ao PIB, a saúde ${ }^{31}$ é a terceira área em termos de volume de gastos desde 1995, sendo superada apenas pela

30 O Gasto Social Federal, calculado pelo IPEA, tem por objetivo mensurar os gastos referentes a programas e ações por áreas de atuação consideradas sociais, tais como: previdência social, benefícios a servidores da União, proteção ao trabalhador, organização agrária, habitação e urbanismo, assistência social, alimentação e nutrição, saúde, educação, cultura e saneamento básico.

31 Segundo a metodologia do IPEA para mensuração do GSF, o gasto da área da saúde é composto pelos gastos totais do MS, excluídos os gastos com alimentação e nutrição, saneamento básico, assistência médica e social a servidores, juros e encargo das dívidas interna e externa e inativos e pensionistas. Entretanto, inclui as despesas de custeio dos Hospitais de Ensino e Universitários (MEC). 
Previdência Social e pela área de Benefícios a Servidores Públicos Federais ${ }^{32}$. Em 2010 foram aplicados na área da saúde recursos equivalentes a 10,8\% do total do GSF, sendo que em 1995 esta área representou 15,9\% do GSF.

Gráfico 01. Evolução da participação do Gasto Social Federal por área de atuação em relação ao PIB - 1995 a 2010

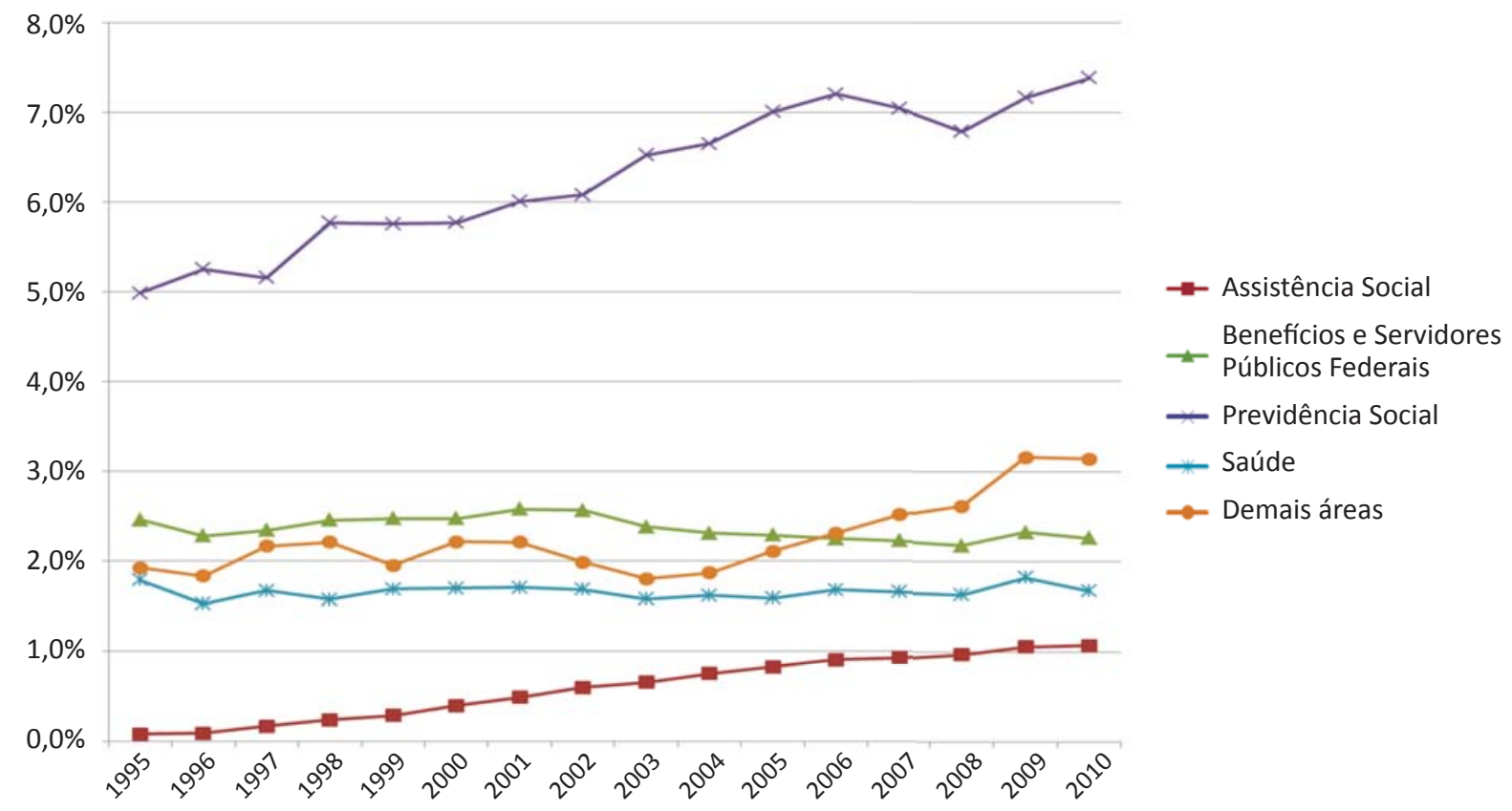

Fonte: Secretaria da Receita Federal, Disoc/IPEA e IBGE.

Em valores absolutos, no período de 1995 a 2010, o gasto federal na área de saúde passou de $R \$ 37$ bilhões para $R$ \$ 67 bilhões, em reais de 2011 (média anual do IPCA), ou seja, teve um crescimento de $80 \%^{33}$. Enquanto isso, o GSF como um todo observou um incremento real de $171 \%$, passando de $\mathrm{R} \$ 231$ bilhões em 1995 para $\mathrm{R} \$ 625$ bilhões em 2010. Esta perda de espaço dentro do GSF pode ter sua origem na crise de financiamento da saúde na década de 90 , quando a saúde deixou de receber os repasses de recursos da Previdência Social que então eram aplicados em assistência médica. A criação de imposto e mais tarde de contribuição sobre a movimentação financeira (CPMF), que veio para ser recurso adicional, acabou substituindo parcela das fontes

32 Nesta área de atuação são consolidadas todas as despesas destinadas ao pagamento de aposentadorias e pensões de servidores públicos federais que saíram da ativa, a servidores dos extintos territórios e estados custeados com recursos da União e a funcionários públicos de empresas estatais pagos com recursos dos Orçamentos Fiscal e da Seguridade Social. São também considerados os gastos relativos a benefícios trabalhistas, como despesas com assistência médica e odontológica, auxílio-transporte, auxílio-refeição etc.

33 Novamente vale lembrar que a análise da "área de atuação" da saúde no GSF é diferente da análise da execução do MS e do gasto em ações e serviços públicos de saúde (ASPS). 
que tradicionalmente financiavam a saúde, como mencionado na seção 2. Por fim, o piso constitucional para as alocações federais no SUS estabelecido pela EC 29, ao invés de se constituir efetivamente no volume mínimo a ser aplicado, foi transformado em "teto" do financiamento federal do SUS, demonstrando uma diminuição da prioridade da saúde nos gastos sociais do Governo Federal.

Gráfico 02. Evolução da participação das áreas de atuação no GSF: 1995 e 2010
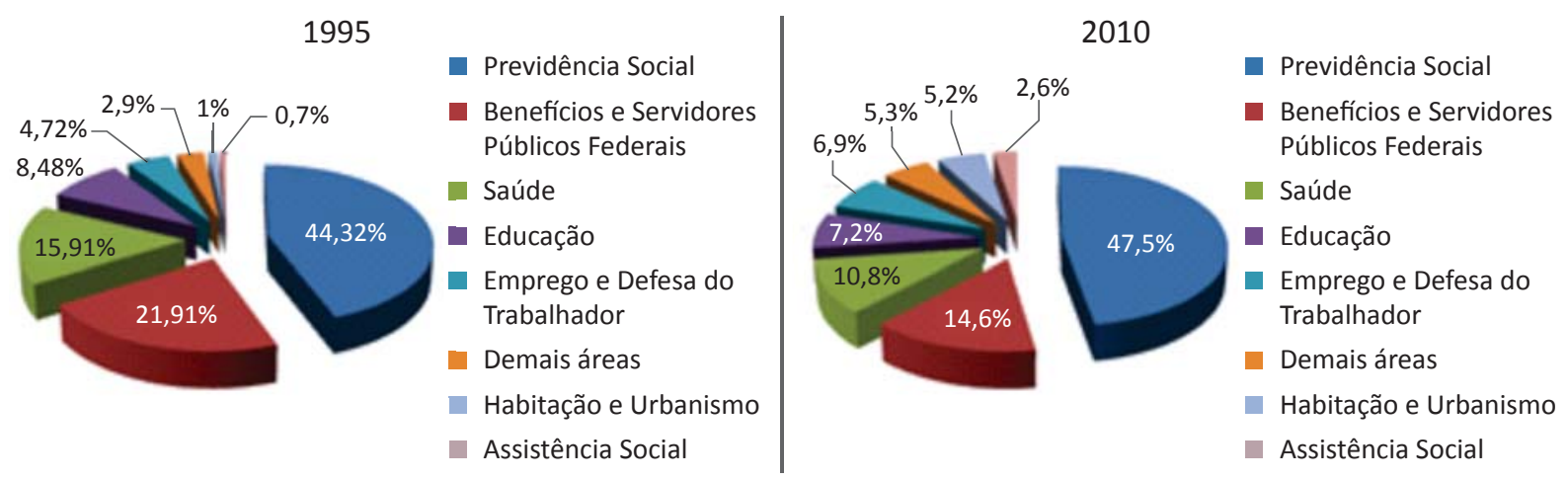

Fonte: GSF/DISOC-IPEA

\subsection{Ministério da Saúde: análise do gasto federal por fonte de financiamento}

Na análise da execução orçamentária do $\mathrm{MS}^{34}$ por fonte chama atenção a posição hegemônica que as contribuições sociais (Contribuição para o Financiamento da Seguridade Social - COFINS, Contribuição Social sobre o Lucro Líquido - CSLL, Contribuição Provisória sobre Movimentação Financeira - CPMF, dentre outras) ocupam no financiamento daquele órgão: entre 1995 e 2011, apenas em 2 anos a participação dessas fontes ficou abaixo de 70\% (1996 e 1999). A partir de 2004, a participação das contribuições sociais ficou acima do patamar de 86\%, apresentando-se como exceção apenas o ano de 2008 (cerca de 72\%), devido à extinção da CPMF em 2007.

A participação percentual das diferentes contribuições sociais no financiamento do MS é muito variada ao longo dos anos. Desde 1997 a CPMF foi uma das principais fontes de financiamento dos gastos do MS. De 2002 a 2007, a CPMF e a CSLL responderam por cerca de 70\% do gasto do MS. Em 2008, com a extinção da CPMF em 2007, a participação dos recursos ordinários se elevou para 20\%, assim como se elevou a participação da COFINS. (Tabela 5). Em 2009, 2010 e 2011, a CSLL e a COFINS foram responsáveis por mais de $80 \%$ do financiamento do gasto do MS. Em 2011,

34 A análise do gasto por fonte de financiamento só foi realizada para a esfera federal uma vez que só esta apresenta informações que possibilitam tal análise. 


\begin{tabular}{|c|c|c|c|c|c|c|c|c|c|c|c|c|c|c|c|}
\hline స్ & 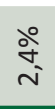 & $\begin{array}{l}\stackrel{\circ}{-1} \\
\text { ○े }\end{array}$ & $\begin{array}{l}\text { ठे } \\
\text { ஓं }\end{array}$ & $\begin{array}{l}\text { mo } \\
0 \\
0\end{array}$ & $\begin{array}{l}\text { ळे } \\
\text { ळे }\end{array}$ & $\stackrel{\stackrel{\circ}{\hat{n}}}{\hat{m}}$ & $\begin{array}{l}\text { ठे } \\
\text { กิ }\end{array}$ & $\begin{array}{l}\text { ठे } \\
\text { ò }\end{array}$ & خ̀ & なें & 1 & 1 & oे & هे & ठั \\
\hline 응 & $\begin{array}{l}\text { ১े } \\
\text { ণे }\end{array}$ & $\begin{array}{l}\text { ठ̊ } \\
\text { ठे }\end{array}$ & 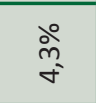 & 1 & $\begin{array}{l}\text { ১े } \\
\text { ठ̀ } \\
\infty\end{array}$ & $\begin{array}{l}\text { ১े } \\
\text { ஸे }\end{array}$ & 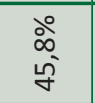 & ১̊ & $\begin{array}{l}\text { ठ̊ㅇ } \\
\text { ó }\end{array}$ & $\stackrel{\text { ڤ̊ }}{\rightarrow}$ & 1 & 1 & $\stackrel{\stackrel{N}{\sim}}{\sim}$ & ๙े & $\begin{array}{l}\text { ठे } \\
\text { ठे }\end{array}$ \\
\hline 용 & $\begin{array}{l}\stackrel{\circ}{+} \\
\stackrel{+}{+}\end{array}$ & $\begin{array}{l}\text { ठे } \\
\text { ơ }\end{array}$ & $\begin{array}{l}\text { ळे } \\
\text { mे }\end{array}$ & 1 & $\begin{array}{l}\stackrel{0}{ } \\
\infty \\
\text { ó }\end{array}$ & $\begin{array}{l}\stackrel{+}{+} \\
\text { gे }\end{array}$ & 空 & 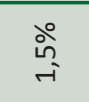 & 。ั & ه্ণ & 1 & 1 & 1 & 。̊ & $\begin{array}{l}\text { ठे } \\
\text { ठे }\end{array}$ \\
\hline $\begin{array}{l}\infty \\
\text { : } \\
\text { N }\end{array}$ & $\begin{array}{l}\text { ১े } \\
\text { ì } \\
\text { ì }\end{array}$ & $\begin{array}{l}\text { ठे } \\
\text { ò }\end{array}$ & $\begin{array}{l}\text { ठे } \\
\stackrel{+}{*}\end{array}$ & 1 & $\begin{array}{l}\stackrel{0}{ } \\
\infty \\
-1 \\
\end{array}$ & $\begin{array}{l}\stackrel{0}{N} \\
\text { ले }\end{array}$ & $\begin{array}{l}\text { oे } \\
\text { हे }\end{array}$ & 今े & ふั & ১े & $\begin{array}{l}\text { ठे } \\
\text { mे }\end{array}$ & 1 & 1 & $\stackrel{\circ}{\stackrel{\circ}{-}}$ & $\begin{array}{l}\text { هั } \\
\text { ठें }\end{array}$ \\
\hline 용 & 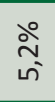 & $\begin{array}{l}\stackrel{0}{\circ} \\
\stackrel{-}{\circ}\end{array}$ & 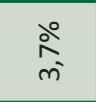 & 1 & 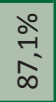 & $\begin{array}{l}\stackrel{\circ}{N} \\
\text { m}^{\circ}\end{array}$ & $\begin{array}{l}\stackrel{+}{+} \\
\text { ปे }\end{array}$ & $\begin{array}{l}\text { ১े } \\
\infty \\
\text { ○े }\end{array}$ & $\begin{array}{l}\text { 。े } \\
\text { ò }\end{array}$ & 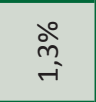 & $\begin{array}{l}\text { ठे } \\
\text { mे }\end{array}$ & 1 & 1 & \begin{tabular}{|c|}
0 \\
$\infty$ \\
0 \\
0
\end{tabular} & $\begin{array}{l}\text { ठें } \\
\text { ठे }\end{array}$ \\
\hline $\begin{array}{l}0 \\
\text { ㅇ } \\
\text { i }\end{array}$ & 웍 & $\begin{array}{l}\stackrel{\circ}{+} \\
\text { ò }\end{array}$ & $\stackrel{\text { ेे }}{\text { mे }}$ & 1 & $\begin{array}{l}\circ \\
\infty \\
\infty \\
\infty \\
\infty\end{array}$ & $\begin{array}{l}\text { ১े } \\
\text { mे } \\
\text { ó }\end{array}$ & 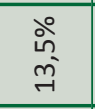 & $\begin{array}{l}\stackrel{\circ}{+} \\
\stackrel{\text { v }}{\mathbf{m}}\end{array}$ & هे & $\stackrel{\text { @̊ }}{-}$ & 1 & 1 & I & ذ̊ & $\begin{array}{l}\text { ठे } \\
\text { ठें }\end{array}$ \\
\hline $\begin{array}{l}\text { ก } \\
\text { 유 }\end{array}$ & $\begin{array}{l}\stackrel{0}{\infty} \\
\stackrel{+}{+}\end{array}$ & $\begin{array}{l}\stackrel{0}{\hat{0}} \\
\text { o }\end{array}$ & 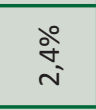 & 1 & $\begin{array}{l}\stackrel{\circ}{m} \\
\text { ने }\end{array}$ & $\begin{array}{l}\grave{n} \\
\text { के } \\
\text { mे }\end{array}$ & $\begin{array}{l}\text { \े } \\
\text { ने }\end{array}$ & $\begin{array}{l}\text { ১े } \\
\text { ஸे } \\
\text { సે }\end{array}$ & 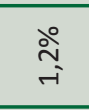 & ๙े & 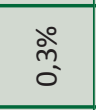 & 1 & 1 & $\begin{array}{l}\text { Oे } \\
0 \\
0\end{array}$ & $\begin{array}{l}\text { هे } \\
\text { ठें }\end{array}$ \\
\hline ষ্ণ & 守 & $\begin{array}{l}\stackrel{\circ}{\circ} \\
\text { 今े }\end{array}$ & 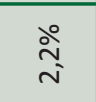 & 1 & $\begin{array}{l}\stackrel{0}{0} \\
\infty^{\circ} \\
\infty\end{array}$ & 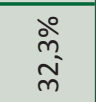 & 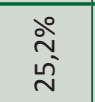 & $\begin{array}{l}\stackrel{\circ}{+} \\
\text { จे }\end{array}$ & $\begin{array}{l}\text { ळे } \\
\text { ᄋे }\end{array}$ & $\begin{array}{l}\text { ○े } \\
\text { مै }\end{array}$ & $\begin{array}{l}\text { 。े } \\
\text { ○े }\end{array}$ & 1 & 1 & 。ํ. & $\begin{array}{l}\text { ठें } \\
\text { ठें }\end{array}$ \\
\hline mo & 웜 & $\stackrel{\circ}{\stackrel{-}{-}}$ & $\stackrel{\text { mे }}{\text { i }}$ & ㅇํ & $\begin{array}{l}\text { ১े } \\
\text { ஸे } \\
\infty\end{array}$ & ১̊ & $\begin{array}{l}\text { ㅇ } \\
\text { - }\end{array}$ & $\begin{array}{l}\text { ১े } \\
\text { in } \\
\text { ñ }\end{array}$ & $\begin{array}{l}\stackrel{0}{0} \\
\infty \\
0\end{array}$ & ö & & 1 & 1 & $\begin{array}{l}\stackrel{0}{0} \\
0 \\
0\end{array}$ & $\begin{array}{l}\text { ठें } \\
\text { ठें }\end{array}$ \\
\hline $\begin{array}{l}\text { No } \\
\text { 을 }\end{array}$ & $\begin{array}{l}\text { ১े } \\
\text { mे } \\
\text { ó }\end{array}$ & ふें & 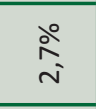 & ১̊ & $\begin{array}{l}\stackrel{0}{m} \\
\stackrel{-1}{\infty}\end{array}$ & $\begin{array}{l}\text { ๖े } \\
\text { N }\end{array}$ & $\begin{array}{l}\stackrel{0}{0} \\
\text { o. } \\
\text { - }\end{array}$ & $\begin{array}{l}\stackrel{\circ}{\circ} \\
\text { के } \\
\text { m }\end{array}$ & ১े & 1 & $\stackrel{\text { ১े }}{\stackrel{i}{i}}$ & 1 & 1 & $\begin{array}{l}\text { ふे } \\
\text { ठ̀ }\end{array}$ & $\begin{array}{l}\text { ठे } \\
\text { ठें }\end{array}$ \\
\hline ర్ & 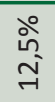 & $\stackrel{\text { ㅇ }}{\text { స̀ }}$ & $\begin{array}{l}\text { ने } \\
\text { हैं }\end{array}$ & 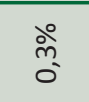 & $\begin{array}{l}\text { ○े } \\
\text { ন }\end{array}$ & ठें & $\begin{array}{l}\text { ๖े } \\
\text { ஸे } \\
\text { m }\end{array}$ & 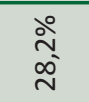 & $\stackrel{\text { సે }}{\text { సे }}$ & 1 & ㅇํ ํㅏㅁ & 1 & 1 & o̊ & $\begin{array}{l}\text { هั } \\
\text { ठे }\end{array}$ \\
\hline $\begin{array}{l}\text { ㅇ } \\
: \\
\text { 은 }\end{array}$ & $\begin{array}{c}\stackrel{0}{9} \\
\text { ம̊ }\end{array}$ & $\stackrel{\stackrel{\circ}{i}}{i}$ & $\stackrel{\stackrel{\circ}{m}}{m_{m}^{2}}$ & ঐ̊ & $\begin{array}{l}\text { 今े } \\
\text { ळे }\end{array}$ & 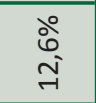 & 월 & 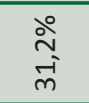 & 1 & 1 & 1 & 1 & 1 & 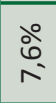 & $\begin{array}{l}\text { ठे } \\
\text { ठे }\end{array}$ \\
\hline হু & 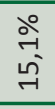 & ㅇํ & $\begin{array}{l}\text { iे } \\
\text { ñ }\end{array}$ & 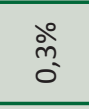 & $\begin{array}{l}\text { ๖े } \\
\text { î } \\
\text { - }\end{array}$ & $\stackrel{\text { }}{\stackrel{\text { Iे }}{\sim}}$ & 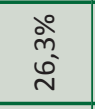 & $\begin{array}{l}\text { 今̊ } \\
\text { సे } \\
\text { N }\end{array}$ & I & 1 & 1 & $\begin{array}{l}\stackrel{\circ}{0} \\
\text { ஸे } \\
\text { ন }\end{array}$ & 1 & $\begin{array}{l}\text { oे } \\
\text { mं }\end{array}$ & $\begin{array}{l}\text { ठें } \\
\text { ठัे }\end{array}$ \\
\hline $\begin{array}{l}\infty \\
\text { ू̆ }\end{array}$ & $\begin{array}{l}\text { ১े } \\
\infty \\
0 \\
\text { - }\end{array}$ & $\begin{array}{l}\stackrel{\circ}{न} \\
\stackrel{-}{-}\end{array}$ & $\begin{array}{l}\text { ১े } \\
\text { i }\end{array}$ & 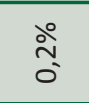 & $\begin{array}{l}\stackrel{0}{ } \\
\infty \\
\text { i- }\end{array}$ & $\begin{array}{l}\text { ○े } \\
\text { ठे }\end{array}$ & $\begin{array}{l}\text { مे } \\
\text { ஸे }\end{array}$ & $\begin{array}{l}\text { ठे } \\
\text { î }\end{array}$ & $\begin{array}{l}\text { ळे } \\
\text { oे }\end{array}$ & 1 & 1 & $\begin{array}{l}\stackrel{\circ}{m} \\
\text { mे } \\
\stackrel{-}{-}\end{array}$ & 1 & 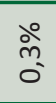 & $\begin{array}{l}\text { ठे } \\
\text { ठे }\end{array}$ \\
\hline ๙ু & هั & $\begin{array}{l}\text { ㅇํ } \\
\text { ஸे }\end{array}$ & ১্ণ & 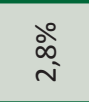 & 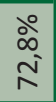 & $\begin{array}{l}\stackrel{\circ}{\text { mे }} \\
\text { ને }\end{array}$ & $\begin{array}{l}\text { ১̊̊ } \\
\text { ஸे }\end{array}$ & $\begin{array}{l}\text { مे } \\
\text { సે }\end{array}$ & 1 & 1 & 1 & $\begin{array}{l}\text { ১ें } \\
\text { જે }\end{array}$ & 1 & $\begin{array}{l}0 \\
\text { oे } \\
0 \\
0\end{array}$ & $\begin{array}{l}\text { ठे } \\
\text { ठ্ণ }\end{array}$ \\
\hline 으 & ঐें & 。ㅇ & ๖े & $\stackrel{\stackrel{े}{\dagger}}{\text { mे }}$ & $\begin{array}{l}\text { ذे } \\
\text { है }\end{array}$ & $\begin{array}{l}\text { হ0 } \\
\text { iे }\end{array}$ & 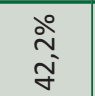 & 1 & $\stackrel{\text { ळे }}{\text { m}^{-}}$ & 1 & 1 & $\begin{array}{l}\text { 今े } \\
\text { సे }\end{array}$ & 1 & $\begin{array}{l}\text { 今े } \\
\text { مे }\end{array}$ & $\begin{array}{l}\text { ठें } \\
\text { ठें }\end{array}$ \\
\hline ผ & $\stackrel{\text { ஸे }}{\mathrm{m}^{\prime}}$ & 웍 & $\stackrel{\stackrel{\circ}{\sim}}{\sim}$ & $\stackrel{\circ}{\stackrel{N}{N}}$ & 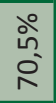 & 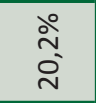 & $\begin{array}{l}\stackrel{0}{\circ} \\
\infty \\
\infty \\
\infty\end{array}$ & I & iे & I & 1 & 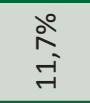 & 1 & $\stackrel{一}{0}_{\infty}^{\circ}$ & $\begin{array}{l}\text { ठें } \\
\text { ठें }\end{array}$ \\
\hline 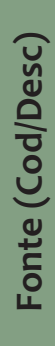 & 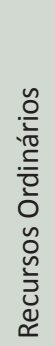 & 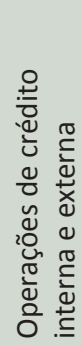 & 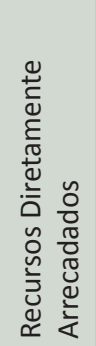 & 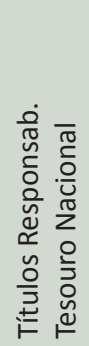 & 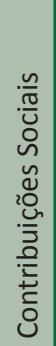 & 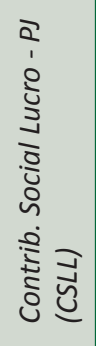 & 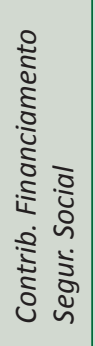 & 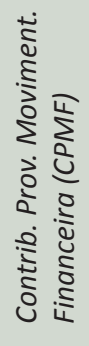 & 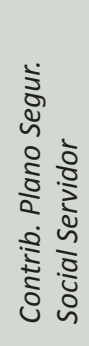 & 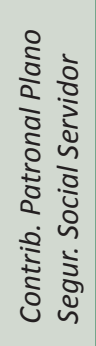 & 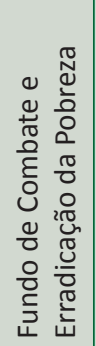 & 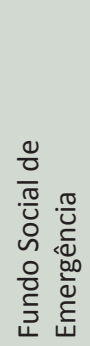 & 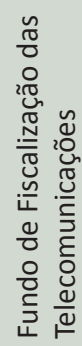 & 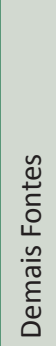 & 。ँ \\
\hline
\end{tabular}


somente a COFINS respondeu por 52\% financiamento do MS. O gráfico 3 representa bem o comportamento variável das contribuições sociais ao longo dos últimos anos.

O gráfico 3 também mostra que, enquanto existiu, a CPMF teve participação bastante estável no financiamento da saúde. Ela financiou, em média, 30,8\% dos recursos do MS no período de 1997 a 2007.

Gráfico 03. Evolução da participação das contribuições sociais no financiamento da saúde — 1995 a 2011

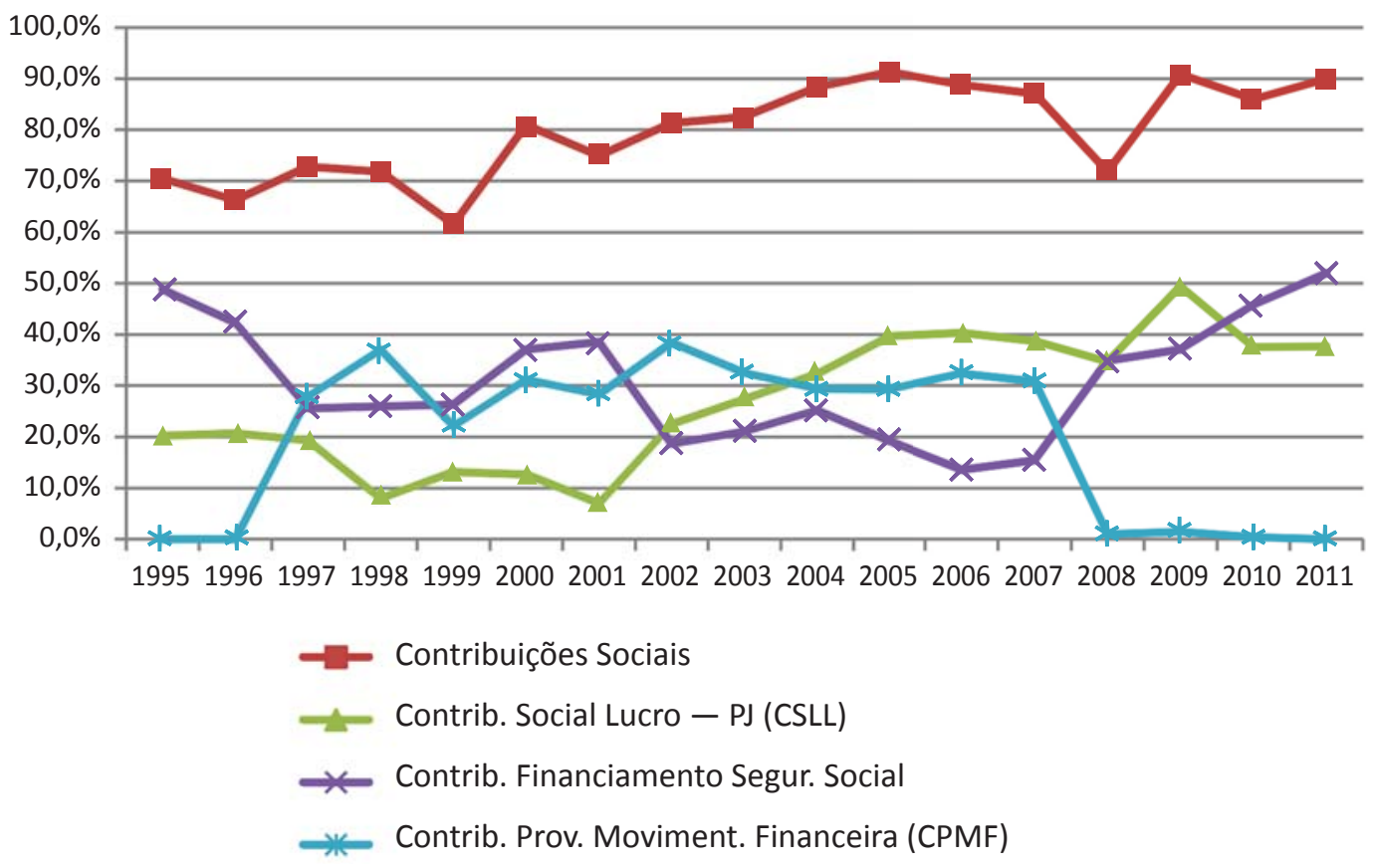

Fonte: SIAFI/SIDOR (Gasto Social Federal - Ipea: 1995 a 2007): SIGA BRASIL (2008, 2009, 2010 e 2011).

De acordo com Servo et. al.(2011), a CPMF

contribuiu muito mais para estabilizar o patamar de recursos orçamentários desse órgão do que para efetivamente elevá-lo de forma mais significativa, fato que pode ser observado no período de 1997 a 2003. Somente a partir de 2004, já com a EC 29 em vigência, é possivel dizer que os recursos da CPMF representaram um aporte de recursos totalmente novo para a saúde no nível federal. 


\begin{tabular}{|c|c|c|c|c|c|c|c|c|c|c|c|c|c|c|c|}
\hline స్ & $\underset{\rightarrow}{q}$ & $\tilde{0}$ & $\stackrel{\sim}{m}$ & $\stackrel{\circ}{i}$ & $\begin{array}{l}0 \\
\stackrel{0}{\circ}\end{array}$ & $\begin{array}{l}0 \\
\stackrel{0}{N}\end{array}$ & $\begin{array}{l}\infty \\
\stackrel{q}{q}^{-}\end{array}$ & 1 & $\tilde{o}$ & İ & 1 & 1 & 1 & $\stackrel{\infty}{0^{-}}$ & $\stackrel{0}{\infty^{-}}$ \\
\hline 울 & $\stackrel{m}{m}^{m}$ & O̊ & $\vec{m}$ & 1 & $\hat{\sigma}$ & $\begin{array}{l}\stackrel{\circ}{N} \\
\text { in }\end{array}$ & $\begin{array}{l}\text { or } \\
\text { n }\end{array}$ & ma & t̊ & $\stackrel{-1}{-1}$ & 1 & 1 & $\underset{r}{6}$ & $\vec{a}$ & $\stackrel{\infty}{i}$ \\
\hline $\begin{array}{l}\text { ̊े } \\
\text { ¿े }\end{array}$ & $\vec{m}$ & : & $\hat{i}$ & 1 & \begin{tabular}{l}
0 \\
\multirow{0}{0}{}
\end{tabular} & $\begin{array}{l}\infty \\
\dot{m}\end{array}$ & $\vec{\sim}$ & $\overrightarrow{-}$ & $\stackrel{0}{0}$ & $\stackrel{m}{\rightarrow}$ & 1 & 1 & 1 & $\begin{array}{l}0 \\
0\end{array}$ & 設 \\
\hline $\begin{array}{l}\infty \\
0 \\
0 \\
\text { N }\end{array}$ & 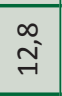 & : & $\stackrel{0}{\sim}$ & 1 & 乡̊ & $\vec{a}$ & $\begin{array}{l}\tilde{N} \\
\tilde{N}\end{array}$ & $\stackrel{6}{0}$ & $\ddot{0}$ & $\mathscr{\varphi}_{0}^{\circ}$ & $\underset{\rightarrow-}{\sigma}$ & 1 & 1 & $\hat{\circ}$ & $\begin{array}{l}\stackrel{0}{0} \\
\tilde{n}^{\prime}\end{array}$ \\
\hline 仓े & $\stackrel{n}{m}$ & r- & $\stackrel{m}{i}$ & 1 & นn & $\stackrel{\infty}{\sim}$ & $\begin{array}{l}\tilde{n} \\
\sigma\end{array}$ & $\begin{array}{l}\text { } \\
\infty \\
\rightarrow\end{array}$ & $\begin{array}{l}0 \\
0\end{array}$ & $\stackrel{\infty}{0}$ & $\stackrel{\text { }}{\rightarrow}$ & 1 & 1 & $\stackrel{\text { Ln }}{0}$ & ث) \\
\hline $\begin{array}{l}\stackrel{2}{ } \\
:\end{array}$ & $\stackrel{\overrightarrow{+}}{+}$ & $\tilde{\sigma}$ & $\stackrel{\infty}{\rightarrow}$ & 1 & $\begin{array}{l}\text { o. } \\
\text { in }\end{array}$ & $\stackrel{0}{\stackrel{\sim}{\sim}}$ & $\hat{\imath}$ & $\underset{\substack{+\sim}}{\stackrel{+}{0}}$ & $\begin{array}{l}0 \\
0^{-}\end{array}$ & gे & ' & 1 & 1 & $\stackrel{n}{0}$ & in \\
\hline $\begin{array}{l}n \\
\stackrel{0}{ } \\
\text { N }\end{array}$ & $\stackrel{0}{i}$ & $\stackrel{+}{\circ}$ & $\stackrel{m}{\rightarrow-}$ & 1 & $\stackrel{\text { ã }}{\text { gे }}$ & $\underset{a}{a}$ & $\begin{array}{l}m \\
\text { o. }\end{array}$ & $\begin{array}{l}\infty \\
\text { ஸे } \\
\text { " }\end{array}$ & $\stackrel{\varphi}{0}$ & $\stackrel{0}{-}$ & 형 & 1 & 1 & $\mathfrak{n}_{0}^{m}$ & ભ્ \\
\hline $\begin{array}{l}\text { ¿े } \\
\text { ¿ }\end{array}$ & $\begin{array}{l}\stackrel{a}{m} \\
\text {. }\end{array}$ & 范 & $\stackrel{-1}{-}$ & 1 & 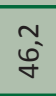 & 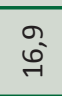 & $\stackrel{\sim}{\vec{r}}$ & 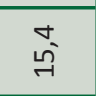 & $\stackrel{n}{0}$ & $\stackrel{m}{o}$ & $\stackrel{\text { Ln }}{0}$ & 1 & 1 & $\stackrel{n}{n}$ & $\begin{array}{l}\text { m } \\
\text { ñ }\end{array}$ \\
\hline$\stackrel{n}{n}$ & $\stackrel{0}{0}_{0}^{-1}$ & Lñ & $\stackrel{-1}{-1}$ & $\tilde{\sigma}$ & $\stackrel{\overrightarrow{0}}{\infty_{m}^{-1}}$ & \begin{tabular}{l}
0 \\
\multirow{I}{*}{}
\end{tabular} & $\hat{\sigma}$ & 오 & ț & $\stackrel{\nabla}{\circ}$ & ' & 1 & 1 & $\mathfrak{m}_{0}^{m}$ & స్ \\
\hline $\begin{array}{l}\tilde{N} \\
\text { ¿ }\end{array}$ & $\vec{n}$ & $\begin{array}{l}\text { o } \\
\text { - }\end{array}$ & $\stackrel{m}{\rightarrow}$ & $\tilde{\sim}$ & $\begin{array}{c}m \\
\text { ó }\end{array}$ & $\begin{array}{l}\mathcal{N} \\
\mathrm{f}\end{array}$ & $\tilde{N}$ & $\begin{array}{l}\circ \\
\text { वे }\end{array}$ & o̊ & 1 & $\stackrel{N}{\sim}$ & 1 & 1 & ț & $\begin{array}{l}6 \\
0 \\
9\end{array}$ \\
\hline$\overline{\grave{d}}$ & $\vec{c}_{6}^{-1}$ & $\vec{r}$ & $\stackrel{\stackrel{n}{N}}{\sim}$ & 형 & $\begin{array}{l}\stackrel{\infty}{ }^{-} \\
\tilde{m}^{\circ}\end{array}$ & $\stackrel{+}{m}$ & $\begin{array}{l}\text { or } \\
\infty \\
\rightarrow\end{array}$ & $\stackrel{\sigma}{\underset{\sim}{\sigma}}$ & $\stackrel{0}{0}$ & 1 & $\stackrel{\sim}{\sim}$ & 1 & 1 & ma & テั \\
\hline $\begin{array}{l}: \\
\stackrel{N}{0}\end{array}$ & $\stackrel{+}{\sim}$ & $\underset{-1}{\sim}$ & $\stackrel{n}{\rightarrow}$ & - & $\begin{array}{l}\text { બે } \\
\text { mे }\end{array}$ & $\stackrel{\infty}{\infty} \stackrel{\infty}{n}^{-}$ & $\begin{array}{l}\text { o } \\
\text { जे }\end{array}$ & $\underset{\sim}{\stackrel{\sim}{\sim}}$ & 1 & 1 & 1 & 1 & 1 & $\stackrel{\mathscr{n}}{m}$ & 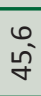 \\
\hline হి & $\hat{\sigma}$ & $\hat{o}$ & $\stackrel{n}{\rightarrow}$ & $\overrightarrow{0}$ & $\stackrel{\sim}{\sim}$ & $\stackrel{\infty}{n}^{\infty}$ & $\begin{array}{l}0 \\
\Rightarrow\end{array}$ & $\hat{\sigma}$ & 1 & 1 & 1 & t্ & 1 & $\stackrel{6}{-}$ & $\stackrel{\sim}{\mathcal{f}}$ \\
\hline $\begin{array}{l}\infty \\
\text { }\end{array}$ & $\stackrel{m}{\sim}$ & $\stackrel{+}{\circ}$ & $\stackrel{\circ}{-}$ & 혀 & $\hat{\sim}$ & $\stackrel{\sim}{m}$ & ثे & $\begin{array}{l}\infty \\
\underset{\sim}{+}\end{array}$ & $\stackrel{m}{0}$ & 1 & 1 & ma & 1 & 둥 & Oे \\
\hline ๙ิ & $\tilde{n}$ & $\tilde{\sigma}$ & $\overrightarrow{-}$ & $\stackrel{\sim}{\sim}$ & $\begin{array}{l}\infty \\
\vec{m} \\
-1\end{array}$ & $\underset{\infty}{+\infty}$ & $\underset{F}{\mathcal{F}}$ & $\underset{\sim}{\sim}$ & 1 & 1 & 1 & $\begin{array}{l}6 \\
\infty\end{array}$ & 1 & ț & $\hat{\tilde{m}}$ \\
\hline ஃั & $\vec{r}$ & $\stackrel{m}{o}$ & o̊ & $\underset{\sim}{\sim}$ & $\begin{array}{l}\text { ָे } \\
\text { }\end{array}$ & $\stackrel{\stackrel{n}{N}}{\sim}$ & $\stackrel{n}{n}$ & 1 & $\stackrel{\sim}{\sim}$ & 1 & 1 & $\tilde{L}_{0}$ & 1 & $\stackrel{\sim}{m}$ & $\begin{array}{l}-1 \\
\text { n. }\end{array}$ \\
\hline ผू & $\underset{-i}{+}$ & $\tilde{0}$ & $\vec{F}$ & $\stackrel{\sim}{\sim}$ & $\begin{array}{l}0 \\
0 \\
\text { " }\end{array}$ & $\begin{array}{l}\infty \\
\infty \\
\infty\end{array}$ & $\stackrel{\sim}{\sim}$ & 1 & $\stackrel{0}{0}$ & 1 & 1 & 호 & 1 & $\stackrel{\varphi}{m}$ & 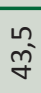 \\
\hline 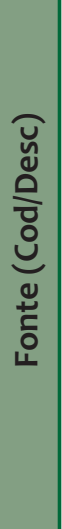 & 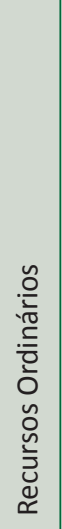 & 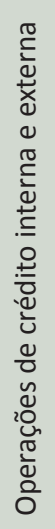 & 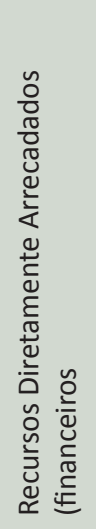 & 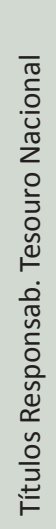 & 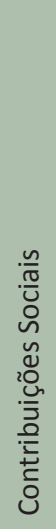 & 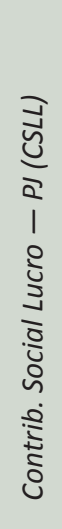 & 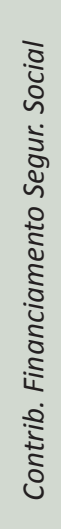 & 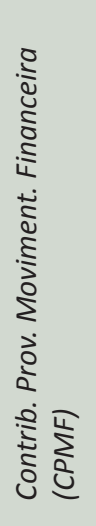 & 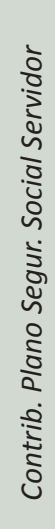 & 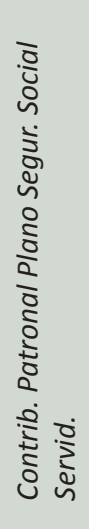 & 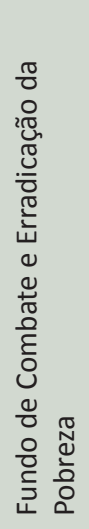 & 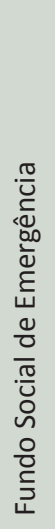 & 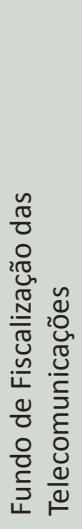 & 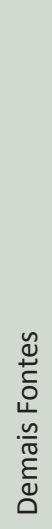 & $\begin{array}{l}\overline{\widetilde{J}} \\
\stackrel{0}{\circ}\end{array}$ \\
\hline
\end{tabular}


O gráfico 4 demonstra claramente que a CPMF, como aporte 100\% adicional para a saúde só ocorreu a partir de 2004. Até então, cerca de 1/3 dos recursos provenientes da CPMF vieram substituir outras fontes existentes ${ }^{35}$, uma vez que, entre 1997 e 2003, os recursos referentes às demais fontes financiaram, em média, R\$ 31,4 bilhões dos gastos em saúde, abaixo do patamar atingido em 1996 (R\$36,1 bilhões).

Gráfico 04. Execução do MS por Fonte de Recursos (CPMF e demais) — 1995 a 2011 (em R\$ bilhões de 2011, atualizados pelo IPCA)

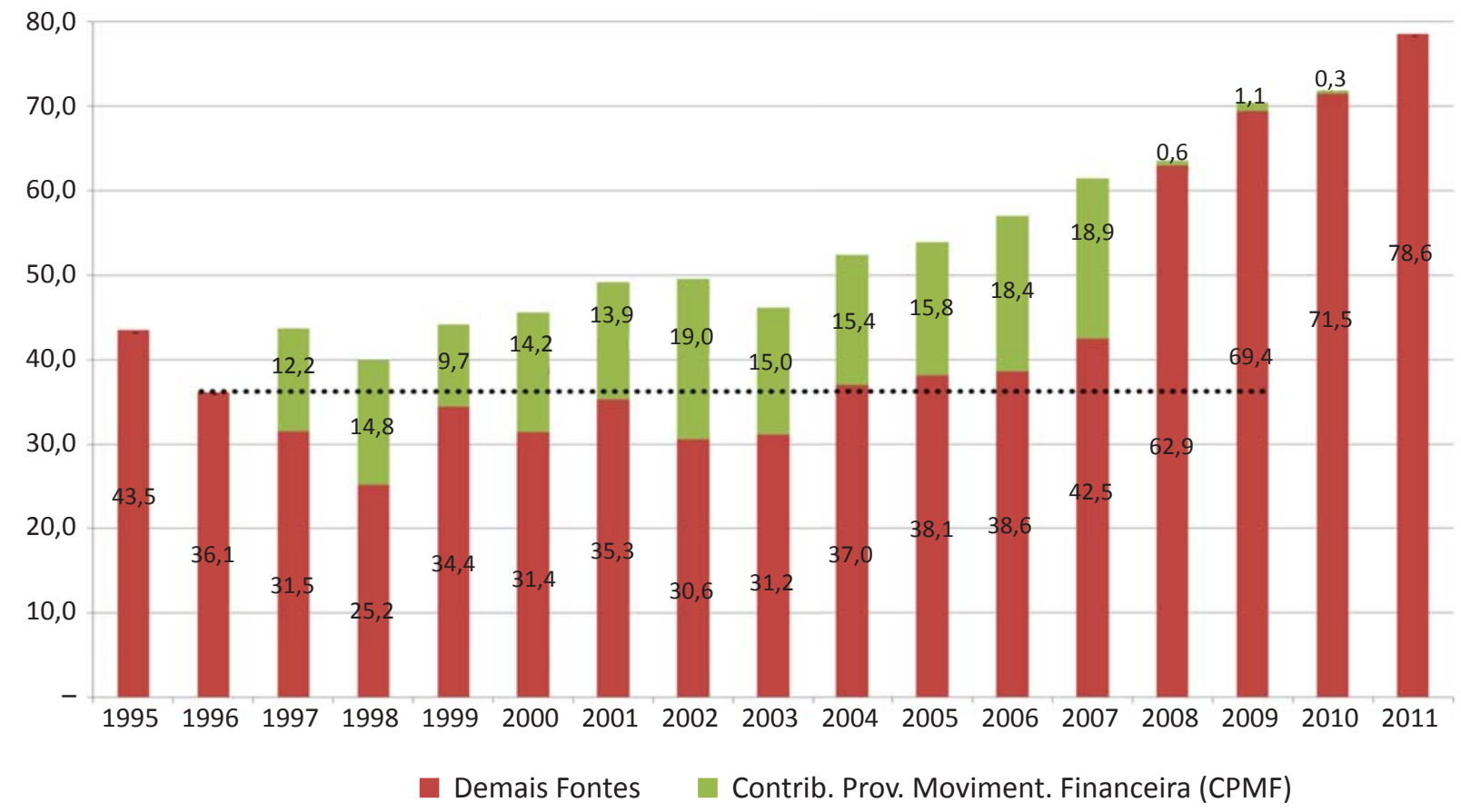

Fonte: SIAFI/SIDOR (Gasto Social Federal — IPEA: 1995 a 2007); SIGA BRASIL (2008 a 2011).

Neste contexto, é importante destacar a importância da EC 29 no financiamento da saúde. Ela assegurou a participação das três esferas de governo no financiamento da saúde e aumento real significativo nas aplicações a partir da definição de recursos mínimos que deveriam ser destinados à saúde. Com este aporte mínimo garantido, o fim da CPMF em 2007 não gerou uma crise no financiamento, assim como ocorreu em 1993, por ocasião do afastamento dos recursos previdenciários do financiamento do setor. Como observado no início desta seção, outras fontes supriram o gasto financiado anteriormente pela CPMF, permitindo que o MS respeitasse o valor mínimo a ser gasto com ações e serviços públicos de saúde.

35 Essa inferência só é possível quando supomos que as demais fontes deveriam financiar, no mínimo, o mesmo valor aportado no ano de 1996, cerca $\mathrm{R} \$ 36,1$ bilhões, quando ainda não existia CPMF. 


\section{3 | ANÁLISE DA REPARTIÇÃO DO VOLUME DE RECURSOS PÚBLICOS DA SAÚDE}

Além de fazer uma análise do volume de recursos que financiam a saúde pública de caráter universal, este texto pretende analisar também a repartição destes recursos. Assim, nesta seção será demonstrada a distribuição dos gastos públicos em saúde por região e, no caso dos gastos federais sua distribuição por programa e modalidade de aplicação.

\section{1 | Distribuição Regional do Gasto Público Total}

Apesar da preocupação do Governo Federal em conferir maior equidade na distribuição dos seus recursos, a distribuição regional do gasto público em saúde é bastante desigual ${ }^{36}$ entre as macrorregiões brasileiras ${ }^{37}$. Em 2008, a região Sudeste tinha o maior gasto público per capita em saúde com um valor de R\$596,07 por habitante. A seguir vinham as regiões Centro-Oeste $(R \$ 556,35)$, Norte $(R \$ 527,10)$ e Sul $(508,82)$. O gasto mais baixo ocorreu no Nordeste onde atingiu o valor per capita de $\mathrm{R} \$ 421,09$, quase $30 \%$ inferior ao gasto público no Sudeste.

Em relação à participação de recursos das três esferas de Governo, nas regiões Norte e Centro-Oeste o gasto per capita médio dos estados é superior ao gasto médio dos municípios. Como na região Centro-Oeste os gastos do DF são considerados exclusivamente como gastos estaduais, este fato pode estar contribuindo para essa situação. Nas regiões Sul e Sudeste, principalmente nessa última, o gasto dos municípios é bastante superior ao per capita médio dos estados dessas regiões (Tabela 7).

Tabela 07. Gasto per capita* com ações e serviços públicos de saúde por esfera de governo e região $-2008$

\begin{tabular}{l|c|c|c|c}
\multicolumn{1}{c|}{ Região } & Federal & Estadual & Municipal & Total \\
\hline Norte & 172,43 & 236,28 & 118,40 & 527,10 \\
\hline Nordeste & 180,20 & 121,28 & 119,61 & 421,09 \\
\hline Sudeste & 196,74 & 167,24 & 232,09 & 596,07 \\
\hline Sul & 221,10 & 102,56 & 185,15 & 508,82 \\
\hline Centro-Oeste & 187,89 & 222,31 & 146,15 & 556,35 \\
\hline Total & $\mathbf{1 9 3 , 0 6}$ & $\mathbf{1 5 4 , 4 8}$ & $\mathbf{1 7 8 , 5 0}$ & $\mathbf{5 2 6 , 0 5}$ \\
\hline
\end{tabular}

Fonte: SPO/MS, SIGA Brasil, SIOPS e IBGE.

* Não foram considerados os gastos realizados na rubrica nacional.

36 Não está em discussão se uma distribuição regional igualitária seria mais justa. De forma mais simplista, a análise foi feita com base no senso comum de que os recursos federais deveriam beneficiar em maior proporção as regiões de menor desenvolvimento social e econômico.

37 Em toda seção que trata da regionalização dos recursos públicos para saúde é utilizado o conceito de ações e serviços públicos de saúde, conforme adotado pelo SIOPS. 
Uma das formas de dimensionar as desigualdades no gasto público, por região, é comparar o gasto regional per capita ao gasto médio nacional per capita, verificando o percentual de diferença (ou afastamento) da média nacional.

Desta forma, observa-se que, entre 2005 e 2008, houve pequena variação nos indicadores. Por exemplo: o gasto público total com saúde na região Sudeste ficou $14,28 \%$ e 13,31\% acima da média nacional nos anos referidos, enquanto que no Nordeste o gasto público foi quase $21 \%$ e 20\% inferior à média nacional nos anos considerados (Gráfico5). O gráfico também mostra que, com exceção das regiões Centro-Oeste e Sul, as variações observadas entre 2005 e 2008 não são significativas ${ }^{38}$.

Gráfico 05. Variação percentual do gasto per capita total em ações e serviços públicos de saúde em cada região em relação ao gasto per capita médio do país — 2005 a 2008

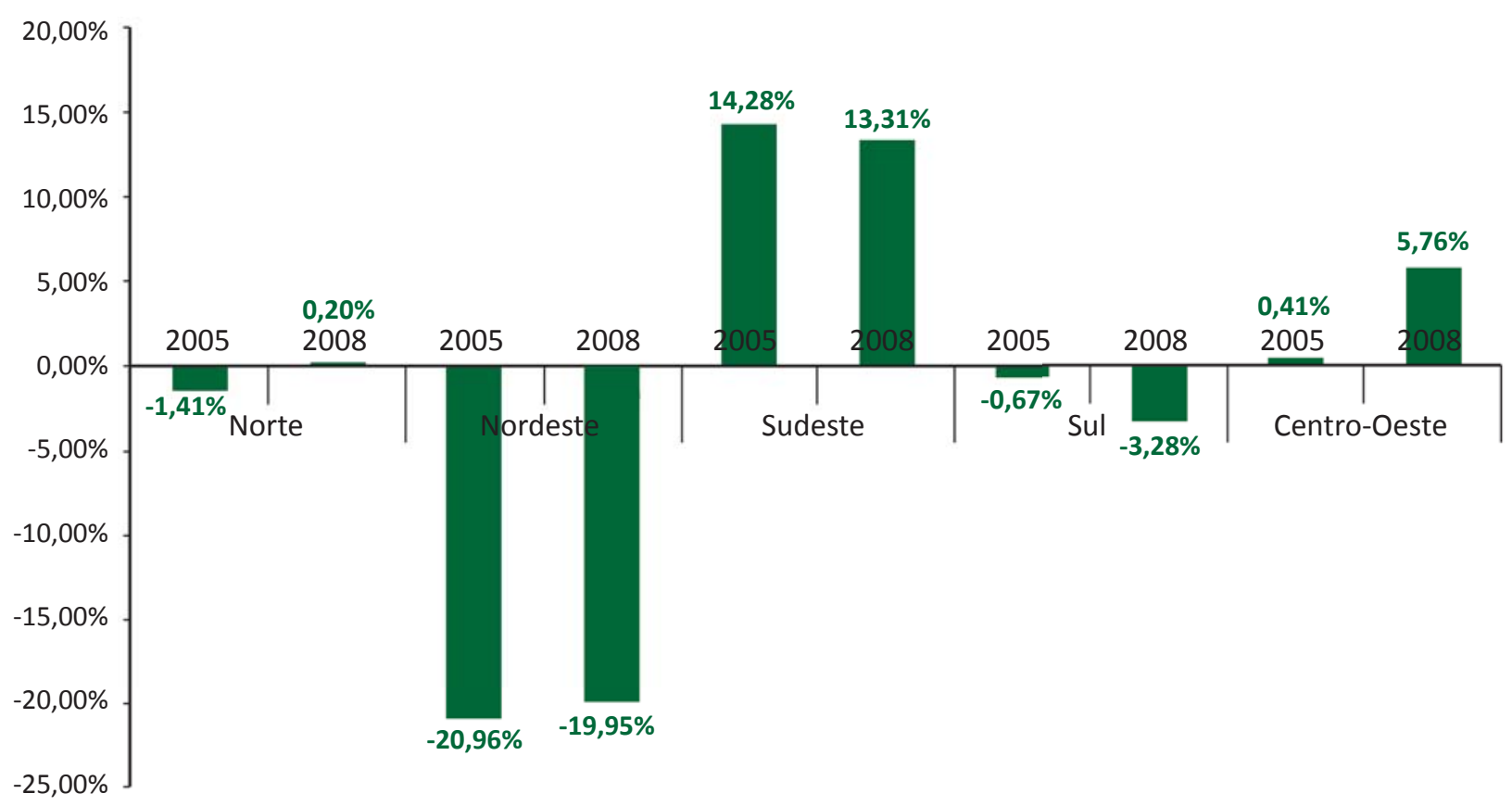

Fonte: SPO/MS, SIGA Brasil e IBGE.

A distribuição do gasto federal é, entretanto, menos desigual do que a do gasto público total. Nesse caso a diferença entre a região Sudeste que recebeu $\mathrm{R} \$$ 196,74 em recursos federais por habitante em 2008 e a região Nordeste ( $\$$ 180,20 por habitante ao ano em 2008) é de cerca de 9,2\%. As regiões Sul (R\$221,10), Sudeste ( $\mathrm{R}$. $196,74)$ e Centro-Oeste $(\mathrm{R} \$ 187,89)$ receberam mais recursos federais que as regiões Nordeste e Norte. (Tabela 7).

38 Não foi possível compatibilizar a série de gastos para período mais longo, entre 2000 e 2008, devido a alterações feitas pelo MS nos critérios de regionalização dos recursos alocados sob a rubrica Nacional, cuja metodologia foi alterada a partir de 2005. 
As variações do gasto federal em valores per capita em relação ao gasto médio nacional, por região, em 2005 e 2008, são apresentadas no Gráfico 6. Observa-se que o gasto federal per capita nas regiões Sul e Sudeste é superior à média nacional, mas com comportamento diferente: crescente no Sul e decrescente no Sudeste. Por outro lado, nas regiões Norte, Nordeste e Centro-Oeste, todas abaixo da média nacional em 2005 e 2008, há uma diminuição da diferença (negativa) em relação à média nacional no período.

Gráfico 06. Variação percentual no gasto federal per capita em ações e serviços públicos de saúde, por região, em relação ao gasto médio no país, em 2005 e 2008

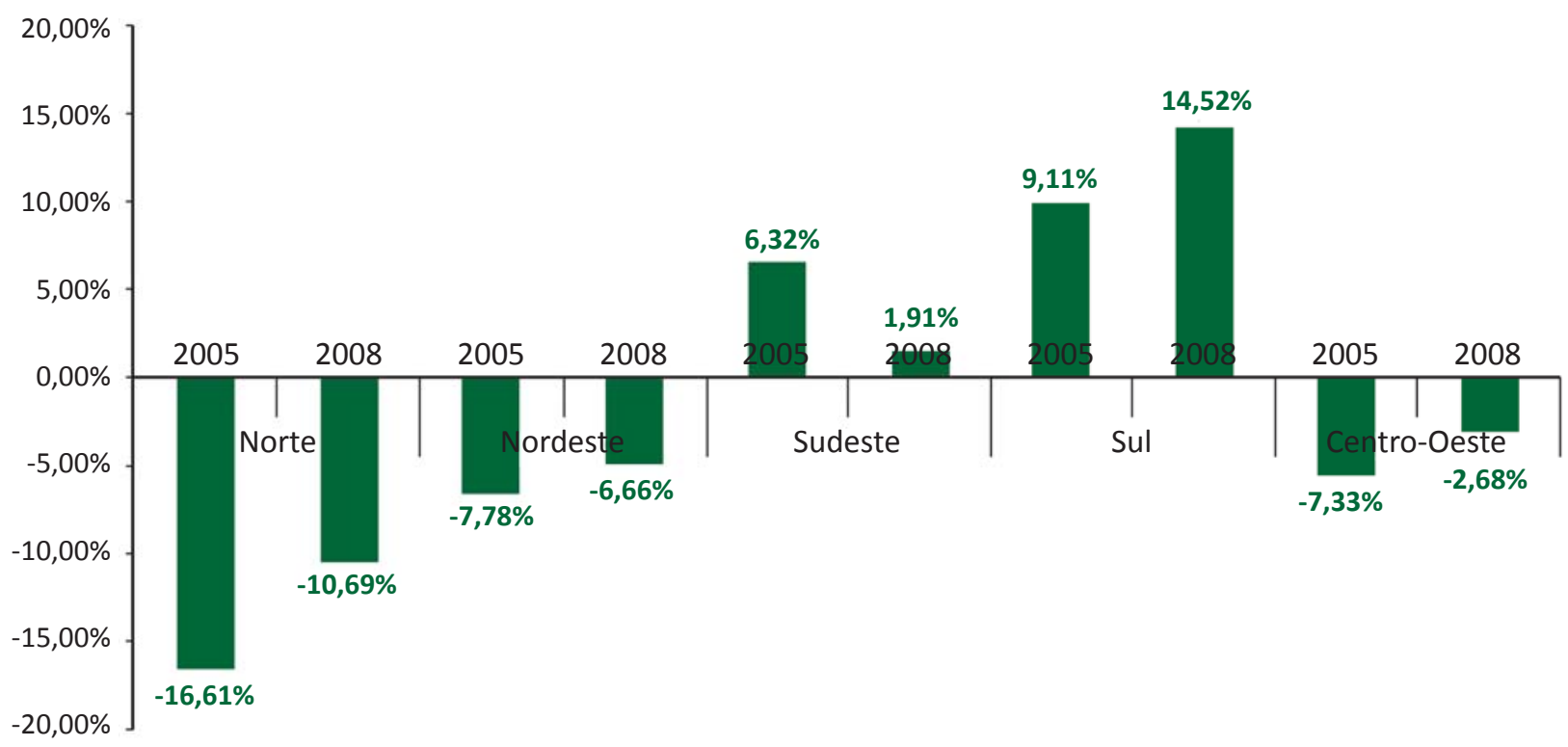

Fonte: SPO/MS, SIGA Brasil e IBGE.

A estrutura do financiamento público da saúde, por região, também é diferenciada. Em termos proporcionais, a participação do gasto federal é mais elevada nas regiões Nordeste e Sul, onde corresponde a $43 \%$ do gasto público total das regiões referidas em 2008. A participação das fontes dos estados, por sua vez, é predominante nas regiões Norte e Centro-Oeste, enquanto recursos originários de fontes dos municípios têm a maior participação no gasto público da região Sudeste (Gráfico 7). 
Gráfico 07. Distribuição (\%) do Gasto per capita em ASPS, por região e esfera de governo — 2008

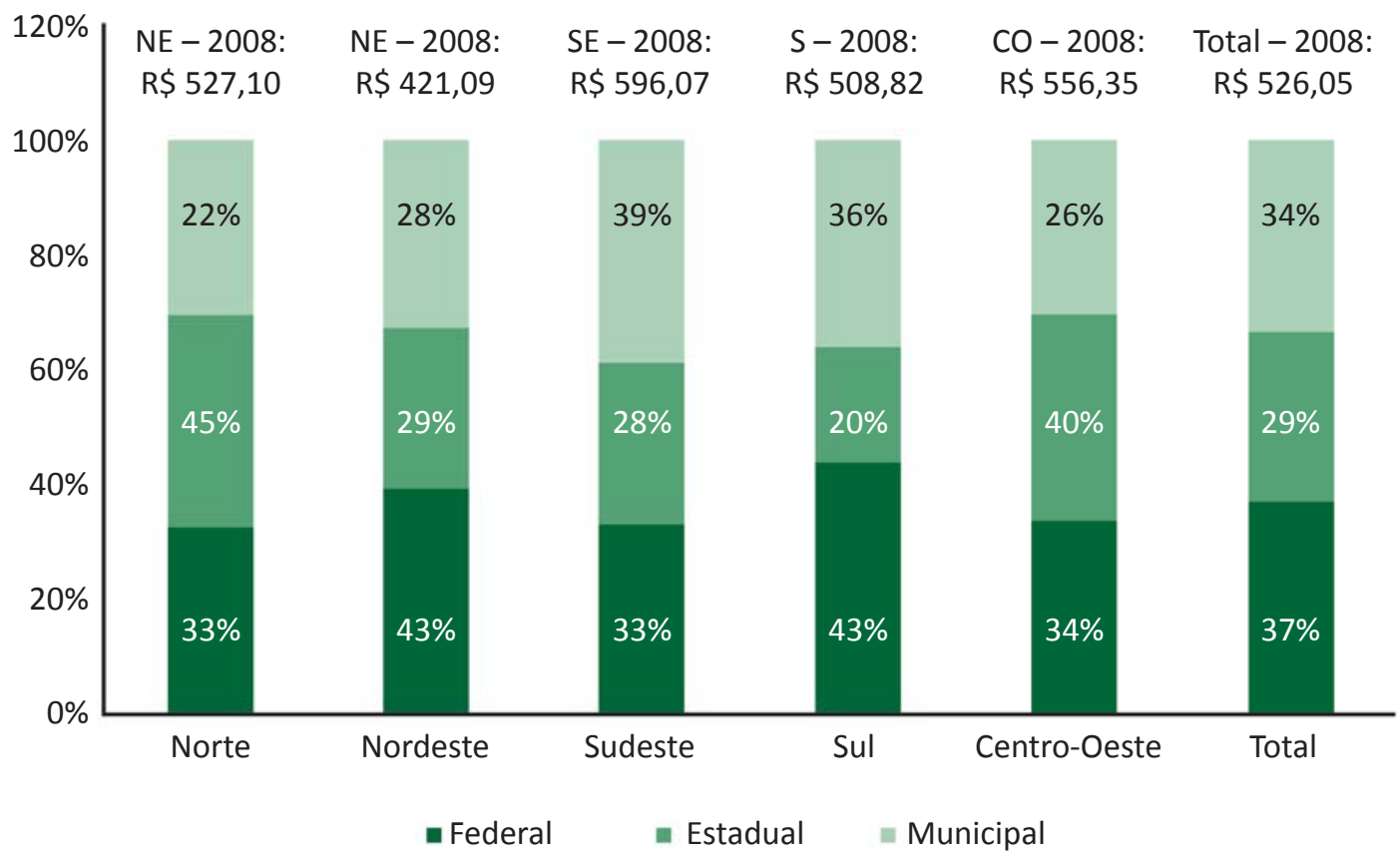

Fonte: SPO/MS, SIGA Brasil, SIOPS e IBGE.

* Não foram considerados os gastos realizados na rubrica nacional.

\subsection{Gastos do Ministério da Saúde por Programas}

Nos últimos anos o SUS apresentou tendência a diminuir seu foco na atenção hospitalar. Um dos caminhos utilizados para isso foi dar maior ênfase à atenção básica, principalmente à estratégia Saúde da Família ${ }^{39}$. Essa prioridade se reflete na alocação de recursos. No gráfico 8 é possível verificar como os gastos com atenção básica aumentam sua participação relativa nos gastos do MS, enquanto há uma diminuição da participação dos gastos com Média e Alta Complexidade (MAC).

A maior parte dos gastos federais com ASPS se concentra na MAC, apesar desta área vir perdendo espaço nos gastos do MS. Também ganham espaço nos dispêndios do MS alguns programas que anteriormente não possuíam ou possuíam pouca visibilidade orçamentária, como por exemplo, o Saúde Bucal, o Farmácia Popular e os gastos com medicamentos excepcionais (Tabela 8).

39 Segundo o próprio MS, o programa é entendido como "uma estratégia de reorientação do modelo assistencial, operacionalizada mediante a implantação de equipes multiprofissionais em unidades básicas de saúde. Estas equipes são responsáveis pelo acompanhamento de um número definido de famílias, localizadas em uma área geográfica delimitada. As equipes atuam com ações de promoção da saúde, prevenção, recuperação, reabilitação de doenças e agravos mais frequentes, e na manutenção da saúde desta comunidade." 
Gráfico 08. Distribuição Percentual dos Gastos em ASPS da União por agrupamentos de programas/ ações, 1995 a 2011

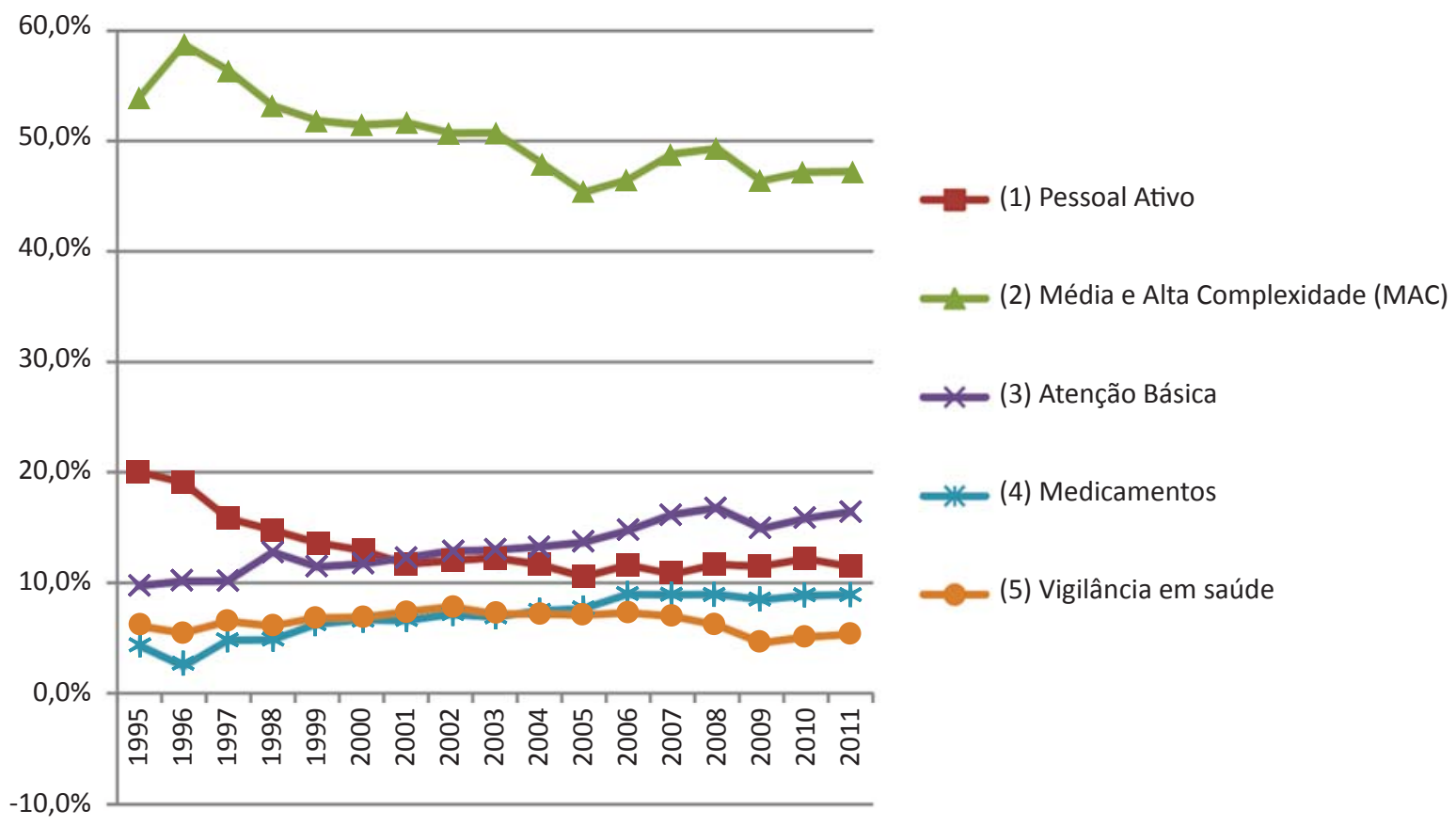

Fonte: SPO/MS; elaboração própria.

Notas: Os programas, ações e linhas de financiamento foram agregados numa tentativa de compatibilizar três planos plurianuais diferentes.

Outra tendência importante desta mudança é no modo com que a atenção de MAC vem sendo tratada. A respeito disso ressalta-se o papel que, desde 2003, vem tendo o Samu e, mais recentemente, as Unidades de Pronto Atendimento (UPAs) na Política Nacional de Atenção às Urgências, que tem por componentes: a atenção pré-hospitalar fixa, a atenção pré-hospitalar móvel, a atenção pré-hospitalar intermediária, atenção hospitalar e atenção pós-hospitalar. ${ }^{40}$

Tanto o Samu quanto as UPAs integram a atenção pré-hospitalar, ou seja, visam atenuar a demanda por atenção hospitalar e/ou otimizar os serviços desta última. O Ministério da Saúde estima que 70\% dos atendimentos em hospitais poderiam ser realizados em UPAs. Assim como a Saúde da Família, os componentes da atenção pré-hospitalar possuem suas limitações, porém demonstram novamente a intenção do SUS em racionalizar o acesso à atenção hospitalar e intensificar a atenção básica. 


\begin{tabular}{|c|c|c|c|c|c|c|c|c|c|c|c|c|c|c|c|c|c|c|c|c|c|}
\hline$\xi$ & $\begin{array}{l}\stackrel{े}{े} \\
\stackrel{-}{-}\end{array}$ & $\begin{array}{l}\stackrel{\text { N̊}}{\tilde{f}} \\
\text { }\end{array}$ & $\begin{array}{l}\text { ठें } \\
\text { ๗े }\end{array}$ & $\begin{array}{l}\text { ఏे } \\
\text { ì }\end{array}$ & $\begin{array}{l}\text { 。े } \\
\text { ó }\end{array}$ & $\mid \begin{array}{l}\stackrel{0}{1} \\
0 \\
0\end{array}$ & 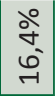 & $\begin{array}{l}\text { वे } \\
6 \\
6\end{array}$ & \begin{tabular}{|l} 
oे \\
0 \\
0 \\
0
\end{tabular} & वे & $\begin{array}{l}\text { సे } \\
\text { o }\end{array}$ & $\begin{array}{l}\text { ठे } \\
\infty\end{array}$ & $\stackrel{\text { ભે }}{\text { - }}$ & \begin{tabular}{l} 
oे \\
\multirow{+}{*}{}
\end{tabular} & $\begin{array}{c}\stackrel{\circ}{\mathrm{i}} \\
\rightarrow\end{array}$ & 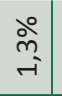 & 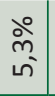 & $\begin{array}{l}\text { ठे } \\
\text { ó }\end{array}$ & $\begin{array}{l}\text { ડे } \\
\text { - }\end{array}$ & $\begin{array}{c}\grave{2} \\
\infty^{\circ}\end{array}$ & $\begin{array}{l}\text { ठे } \\
\text { ठें }\end{array}$ \\
\hline ¿े & \begin{tabular}{l}
$\stackrel{0}{a}$ \\
\multirow{1}{*}{}
\end{tabular} & 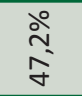 & $\begin{array}{l}\stackrel{\circ}{\hat{े}} \\
\text { ̧े }\end{array}$ & 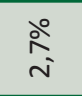 & $\begin{array}{l}\text { ¿े } \\
\text { ó }\end{array}$ & $\begin{array}{l}0 \\
0 \\
0 \\
0\end{array}$ & $\begin{array}{ll}0 \\
0 \\
n \\
\end{array}$ & $\begin{array}{l}\text { ळे } \\
\text { ஸे }\end{array}$ & $\begin{array}{l}\circ \\
\text { oे } \\
\sigma\end{array}$ & $\begin{array}{l}\stackrel{0}{0} \\
0 \\
0\end{array}$ & $\begin{array}{l}\stackrel{0}{0} \\
\text { ó }\end{array}$ & $\begin{array}{l}\stackrel{\circ}{ } \\
\infty\end{array}$ & $\underset{\sim}{\stackrel{\circ}{\circ}}$ & $\begin{array}{l}\text { วิे } \\
\text { ஸे }\end{array}$ & $\begin{array}{l}\stackrel{0}{\circ} \\
\hat{-}\end{array}$ & $\begin{array}{l}\stackrel{0}{0} \\
\hat{0}^{\circ}\end{array}$ & $\begin{array}{l}\stackrel{\circ}{\circ} \\
\dot{1}\end{array}$ & $\begin{array}{l}\stackrel{\circ}{\circ} \\
\stackrel{-}{0}\end{array}$ & $\begin{array}{l}\stackrel{0}{0} \\
\stackrel{-}{-}\end{array}$ & $\begin{array}{l}\stackrel{\circ}{ } \\
\sigma^{2}\end{array}$ & $\begin{array}{l}\text { ठें } \\
\text { ठิे }\end{array}$ \\
\hline ஜి & $\begin{array}{l}\text { 우 } \\
-1 \\
-1\end{array}$ & $\begin{array}{l}\stackrel{9}{\circ} \\
\stackrel{\sigma}{\sigma}\end{array}$ & 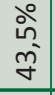 & $\begin{array}{l}\text { ১े } \\
\text { ஸे } \\
\text { i }\end{array}$ & & & $\begin{array}{l}\text { ò } \\
\text { जे }\end{array}$ & $\begin{array}{ll}0 \\
0 \\
10 \\
\end{array}$ & $\begin{array}{l}\sigma^{\circ} \\
\infty^{-} \\
\end{array}$ & $\begin{array}{l}\circ \\
\text { ò } \\
0\end{array}$ & $\begin{array}{c}\grave{0} \\
\text { ò }\end{array}$ & $\begin{array}{l}\stackrel{\circ}{\circ} \\
\infty \\
\text { co }\end{array}$ & ㅇํㄱ & $\begin{array}{l}\stackrel{0}{ } \\
\text { นे }\end{array}$ & $\stackrel{\text { ڤे }}{\mathrm{r}}$ & $\begin{array}{l}\text { oे } \\
\text { - }\end{array}$ & 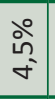 & ठ̊. & $\begin{array}{l}\stackrel{\circ}{\rightarrow} \\
\text { ১े }\end{array}$ & $\begin{array}{l}\stackrel{0}{m} \\
\stackrel{-}{\sim}\end{array}$ & $\begin{array}{l}\text { ठें } \\
\text { ठิे }\end{array}$ \\
\hline$\stackrel{\infty}{8}$ & $\begin{array}{l}\grave{0} \\
\hat{y} \\
-1\end{array}$ & $\begin{array}{l}\stackrel{\circ}{m} \\
\text { के }\end{array}$ & $\begin{array}{l}\stackrel{\circ}{0} \\
g^{\circ}\end{array}$ & $\begin{array}{l}\text { Oे } \\
\text { mे }\end{array}$ & & & $\begin{array}{l}0 \\
0 \\
0 \\
0 \\
-1\end{array}$ & $\begin{array}{l}20 \\
\vdots \\
0\end{array}$ & $\begin{array}{l}20 \\
\vdots \\
0\end{array}$ & वे & $\begin{array}{c}\stackrel{0}{0} \\
m_{0}^{\prime} \\
0^{\prime}\end{array}$ & $\begin{array}{l}\stackrel{0}{ } \\
\text { oे }\end{array}$ & ڤे & $\begin{array}{l}\stackrel{0}{2} \\
+\end{array}$ & $\begin{array}{l}\circ \\
\infty \\
- \\
-1\end{array}$ & $\begin{array}{l}0 \\
\text { oे } \\
\text { i }\end{array}$ & $\begin{array}{l}\text { \े } \\
\text { రे }\end{array}$ & なे & $\begin{array}{l}\stackrel{0}{0} \\
\stackrel{\sim}{v}\end{array}$ & $\begin{array}{l}\text { oे } \\
\text { in }\end{array}$ & $\begin{array}{l}\text { ठें } \\
\text { ठิे }\end{array}$ \\
\hline ᄋ & $\begin{array}{l}\text { oे } \\
\infty \\
0 \\
-1\end{array}$ & $\begin{array}{l}\text { ळे } \\
\infty^{\circ}\end{array}$ & $\begin{array}{l}\text { ○े } \\
\text { ơ } \\
\text { yे }\end{array}$ & $\begin{array}{l}\text { ठे } \\
\text { mे }\end{array}$ & & & 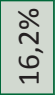 & 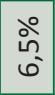 & $\begin{array}{l}\stackrel{0}{2} \\
\tilde{\sigma}^{2}\end{array}$ & ò & $\begin{array}{l}\stackrel{\circ}{\circ} \\
\text { cे }\end{array}$ & $\begin{array}{l}\stackrel{\circ}{ } \\
\infty\end{array}$ & $\stackrel{\circ}{\stackrel{一}{m}}$ & \begin{tabular}{l}
$\stackrel{0}{\circ}$ \\
\multirow{\sigma}{*}{}
\end{tabular} & $\begin{array}{l}\stackrel{0}{2} \\
0^{\prime}\end{array}$ & $\begin{array}{l}\stackrel{0}{2} \\
0^{\circ}\end{array}$ & 웃 & 号 & $\stackrel{\stackrel{\circ}{\circ}}{\sim}$ & $\begin{array}{l}\text { ळे } \\
\text { ஸे }\end{array}$ & $\begin{array}{l}\text { Оे. } \\
\text { Оें }\end{array}$ \\
\hline$\stackrel{\circ}{\circ}$ & $\begin{array}{l}\text { هి } \\
6 \\
-1\end{array}$ & $\begin{array}{l}\text { 우 } \\
\text { के }\end{array}$ & $\begin{array}{l}\stackrel{0}{0} \\
\tilde{y}^{-}\end{array}$ & $\begin{array}{l}\stackrel{\circ}{i} \\
\text { i }\end{array}$ & & & \begin{tabular}{l}
$\stackrel{\circ}{N}$ \\
\multirow{-}{*}{}
\end{tabular} & $\begin{array}{l}\stackrel{0}{0} \\
\text { రิ }\end{array}$ & $\begin{array}{l}\stackrel{0}{0} \\
\infty^{\prime}\end{array}$ & 。े & $\begin{array}{l}\stackrel{0}{0} \\
\text { ó }\end{array}$ & $\begin{array}{l}\text { oे } \\
\text { oे }\end{array}$ & $\stackrel{\stackrel{\circ}{+}}{\stackrel{\nabla}{-}}$ & $\begin{array}{l}\stackrel{े}{+} \\
\dot{m}\end{array}$ & 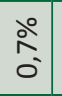 & 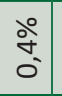 & $\stackrel{\stackrel{\circ}{\sim}}{\sim}$ & $\begin{array}{l}\text { ठ̊ } \\
\text { ó }\end{array}$ & $\begin{array}{l}\text { ১े } \\
\text { - }\end{array}$ & $\begin{array}{l}\text { oे } \\
\text { oे }\end{array}$ & $\begin{array}{l}\text { ठें } \\
\text { ठิे }\end{array}$ \\
\hline 능 & $\begin{array}{l}\text { ১ें } \\
\text { on } \\
\text { ने }\end{array}$ & $\begin{array}{l}\stackrel{\circ}{m} \\
\text { ֶ̊ }\end{array}$ & $\begin{array}{l}\text { ठे } \\
\text { गे }\end{array}$ & $\stackrel{\stackrel{\circ}{\sim}}{i}$ & & & $\begin{array}{l}\text { ठे } \\
\dot{0} \\
\overrightarrow{7}\end{array}$ & $\begin{array}{l}\stackrel{0}{0} \\
\tilde{c}^{-}\end{array}$ & 귬 & خ̀े & $\begin{array}{l}\stackrel{\circ}{2} \\
\stackrel{-}{0}\end{array}$ & 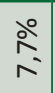 & $\begin{array}{c}\stackrel{\circ}{\infty} \\
\text { nj }\end{array}$ & $\begin{array}{l}\stackrel{\circ}{\vec{m}} \\
\mathrm{~m}\end{array}$ & 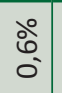 & $\begin{array}{l}\text { वे } \\
\stackrel{-}{0}\end{array}$ & $\stackrel{\circ}{\stackrel{ }{n}}$ & $\begin{array}{l}\text { ఏें } \\
\text { in }\end{array}$ & $\stackrel{\circ}{\stackrel{\sim}{-}}$ & $\begin{array}{l}\stackrel{0}{\hat{2}} \\
\infty^{\circ}\end{array}$ & $\begin{array}{l}\text { ठें } \\
\text { ठें }\end{array}$ \\
\hline ১ & $\begin{array}{l}\stackrel{0}{N} \\
-1 \\
-1\end{array}$ & $\begin{array}{l}\text { वे } \\
\text { के }\end{array}$ & $\begin{array}{l}\text { ○े } \\
\text { o } \\
y^{\prime}\end{array}$ & $\stackrel{\stackrel{\circ}{m}}{\stackrel{\text { }}{N}}$ & & & 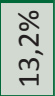 & $\mid \begin{array}{l}\stackrel{0}{+} \\
\sigma^{\prime}\end{array}$ & $\mid \begin{array}{l}\text { oे } \\
6 \\
6\end{array}$ & $\begin{array}{c}\text { సे } \\
\text { ó }\end{array}$ & $\begin{array}{l}\text { 今े } \\
\text { ठे }\end{array}$ & 今̊ & 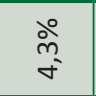 & $\begin{array}{c}\stackrel{0}{i n} \\
\sim \\
\sim\end{array}$ & $\begin{array}{l}\stackrel{0}{6} \\
0 \\
0\end{array}$ & $\begin{array}{l}\text { ठे. } \\
0 \\
0\end{array}$ & 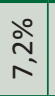 & 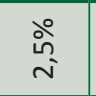 & 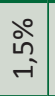 & $\begin{array}{c}\stackrel{\circ}{m} \\
\infty^{-}\end{array}$ & $\begin{array}{l}\text { ठें } \\
\text { ठิ๋ }\end{array}$ \\
\hline$\stackrel{m}{\varnothing}$ & 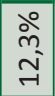 & 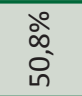 & $\begin{array}{l}\text { ○े } \\
\infty \\
\infty^{\circ}\end{array}$ & ১̊̀ & & & \begin{tabular}{|l|}
0 \\
0 \\
$m$ \\
-1
\end{tabular} & 今̊ & $\mid \begin{array}{l}0 \\
0^{\circ} \\
6^{-}\end{array}$ & $\begin{array}{l}\stackrel{0}{a} \\
a_{0}^{-}\end{array}$ & $\begin{array}{l}\text { ठ̊. } \\
\text { ó }\end{array}$ & $\begin{array}{l}\text { oे } \\
\text { ঢ }\end{array}$ & $\stackrel{\stackrel{\circ}{+}}{\stackrel{\circ}{+}}$ & $\begin{array}{l}\text { هे } \\
\text { ᄀ }\end{array}$ & $\begin{array}{l}\stackrel{0}{0} \\
0 \\
0\end{array}$ & $\begin{array}{l}\text { ठे. } \\
\text { o. }\end{array}$ & 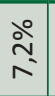 & 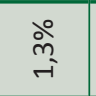 & $\begin{array}{l}\stackrel{\circ}{f} \\
\stackrel{0}{\circ}\end{array}$ & 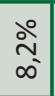 & $\begin{array}{l}\text { ठें } \\
\text { ठें }\end{array}$ \\
\hline ㄱ & \begin{tabular}{l} 
o̊ \\
ì \\
\multirow{1}{*}{}
\end{tabular} & $\begin{array}{l}\text { مீ } \\
\text { ì } \\
\text { กे }\end{array}$ & $\begin{array}{l}\stackrel{\circ}{\stackrel{\circ}{~}} \\
\text { f }\end{array}$ & ஸे & & & $\begin{array}{l}\text { ภ̊ } \\
\text { ন } \\
\end{array}$ & 今̊ & $\begin{array}{l}\text { ○े } \\
\text { mo } \\
\text { மீ }\end{array}$ & $\begin{array}{l}\text { oे } \\
\text { ó }\end{array}$ & $\begin{array}{l}\text { ठे. } \\
\text { oे }\end{array}$ & $\stackrel{\stackrel{\circ}{N}}{\stackrel{N}{N}}$ & $\begin{array}{l}\stackrel{0}{6} \\
\text { - }\end{array}$ & $\begin{array}{c}\stackrel{0}{\sigma} \\
\text { - }\end{array}$ & $\begin{array}{l}\stackrel{0}{\hat{0}} \\
0^{\prime}\end{array}$ & $\begin{array}{l}\text { ठें } \\
0 \\
0\end{array}$ & $\begin{array}{l}\stackrel{\circ}{\infty} \\
\stackrel{1}{\wedge}\end{array}$ & $\begin{array}{l}\text { ठे } \\
\text { ने }\end{array}$ & 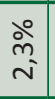 & $\begin{array}{l}\stackrel{\circ}{न} \\
\sigma^{-}\end{array}$ & $\begin{array}{l}\text { ठें } \\
\text { ठें }\end{array}$ \\
\hline - & $\begin{array}{l}\stackrel{0}{\hat{2}} \\
-1\end{array}$ & $\begin{array}{l}\grave{n} \\
\text { iे }\end{array}$ & $\begin{array}{l}\text { ๖े } \\
\text { ஸे } \\
\text { के }\end{array}$ & $\stackrel{\text { ஸे }}{\text { nे }}$ & & & 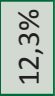 & $\begin{array}{l}0 \\
\delta^{\circ} \\
\infty^{-}\end{array}$ & $\begin{array}{l}\stackrel{\circ}{ } \\
\stackrel{+}{+}\end{array}$ & $\begin{array}{l}0 \\
\text { ò } \\
\text { - }\end{array}$ & $\begin{array}{l}\text { oें } \\
\text { o. }\end{array}$ & $\begin{array}{l}\circ \\
0 \\
6 \\
0^{\circ}\end{array}$ & $\begin{array}{l}\stackrel{0}{\circ} \\
\text { n' }\end{array}$ & $\begin{array}{l}0 \\
\text { ò } \\
\text { i }\end{array}$ & $\begin{array}{l}\stackrel{0}{0} \\
\hat{0}^{\circ}\end{array}$ & $\begin{array}{l}\text { वें } \\
\text { ó }\end{array}$ & $\underset{\stackrel{\circ}{\sim}}{\stackrel{\circ}{N}}$ & $\begin{array}{l}\text { ১े } \\
\text { o. } \\
\text { o' }\end{array}$ & $\begin{array}{l}\stackrel{\circ}{\dagger} \\
\text { जे }\end{array}$ & $\begin{array}{l}\stackrel{0}{m} \\
\stackrel{+}{*}\end{array}$ & $\begin{array}{l}\text { ¿ें } \\
\text { ठें }\end{array}$ \\
\hline ৪ & $\begin{array}{l}\text { ภे } \\
\text { ন }\end{array}$ & $\begin{array}{l}\stackrel{\circ}{\sigma} \\
\text { ì } \\
\text { ก' }\end{array}$ & $\begin{array}{l}\text { वे } \\
\vec{a}^{\prime} \\
\stackrel{0}{+}\end{array}$ & $\stackrel{\stackrel{\circ}{\oplus}}{\text { mे }}$ & & & $\begin{array}{l}\stackrel{0}{\hat{N}} \\
\stackrel{-}{-} \\
\end{array}$ & $\begin{array}{l}\text { ○ें } \\
\text { in } \\
\end{array}$ & $\begin{array}{l}\text { \े } \\
\text { mे }\end{array}$ & $\begin{array}{l}0 \\
\text { oे } \\
0\end{array}$ & $\begin{array}{l}\text { ठे } \\
\text { oे }\end{array}$ & $\begin{array}{l}80 \\
6 \\
6 \\
\end{array}$ & 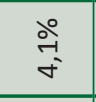 & $\begin{array}{c}\stackrel{0}{0} \\
\infty \\
-i \\
\end{array}$ & $\begin{array}{c}\circ \\
\infty \\
0^{\circ}\end{array}$ & $\begin{array}{l}\text { oे } \\
\text { o. }\end{array}$ & $\begin{array}{l}\text { ठे } \\
\text { 6’ }\end{array}$ & $\begin{array}{l}\stackrel{2}{\hat{\imath}} \\
0^{\circ}\end{array}$ & $\begin{array}{l}0 \\
\text { ळे } \\
0 \\
0\end{array}$ & $\begin{array}{l}\text { ठे } \\
\infty\end{array}$ & 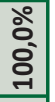 \\
\hline হু & $\begin{array}{l}\text { dे } \\
\text { mे } \\
\vec{r}\end{array}$ & $\begin{array}{l}\text { oे } \\
\text { जे }\end{array}$ & $\begin{array}{l}\text { ઠे } \\
\text { テे }\end{array}$ & $\begin{array}{l}\stackrel{0}{ } \\
\text { ठे }\end{array}$ & & & $\begin{array}{l}\stackrel{2}{+} \\
\stackrel{-}{-1} \\
\end{array}$ & $\begin{array}{l}\grave{0} \\
\text { の่ }\end{array}$ & $\begin{array}{l}\stackrel{0}{\infty} \\
\text { - }\end{array}$ & $\begin{array}{l}\text { oे } \\
0 \\
0\end{array}$ & $\begin{array}{l}\text { o̊ } \\
\text { o }\end{array}$ & $\begin{array}{l}\stackrel{0}{m} \\
\text { c}^{-}\end{array}$ & ठ̊ํ & $\begin{array}{c}\circ \\
\text { oे } \\
-i\end{array}$ & 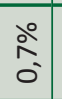 & $\begin{array}{l}\text { ठें } \\
0^{\circ}\end{array}$ & $\begin{array}{l}\text { ○े } \\
\text { o } \\
0^{-}\end{array}$ & $\begin{array}{l}\text { ১े } \\
\text { o } \\
0^{-}\end{array}$ & $\begin{array}{l}\stackrel{\circ}{\vec{े}} \\
\stackrel{-}{-}\end{array}$ & $\begin{array}{l}\stackrel{0}{-} \\
\infty \\
\infty\end{array}$ & $\begin{array}{l}\text { ठें } \\
\text { ठें }\end{array}$ \\
\hline $\begin{array}{l}\infty \\
\text { } \\
\text { ने }\end{array}$ & \begin{tabular}{l} 
১े \\
$\infty$ \\
\multirow{J}{*}{}
\end{tabular} & సેे & $\begin{array}{l}\text { ○े } \\
\infty \\
\infty^{\circ}\end{array}$ & $\stackrel{\circ}{\stackrel{+}{\circ}}$ & & & 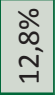 & $\begin{array}{l}\stackrel{\circ}{m} \\
\stackrel{-}{-}\end{array}$ & ڤั่ & $\begin{array}{l}\text { oे } \\
\text { ó }\end{array}$ & $\begin{array}{l}\text { वे. } \\
\text { o. }\end{array}$ & $\begin{array}{l}\stackrel{0}{\infty} \\
\infty \\
-\end{array}$ & ১̊ & $\begin{array}{l}\stackrel{\circ}{\circ} \\
\stackrel{-}{-}\end{array}$ & $\begin{array}{c}\stackrel{0}{0} \\
m_{0}^{-}\end{array}$ & $\begin{array}{l}0 \\
\text { ò } \\
0\end{array}$ & $\begin{array}{l}\stackrel{\circ}{0} \\
\hat{\sigma}^{-}\end{array}$ & ণे & $\begin{array}{l}\text { ठे } \\
\text { ठे }\end{array}$ & ১̊ํ & $\begin{array}{l}\text { Оें } \\
\text { Оें }\end{array}$ \\
\hline Дু & 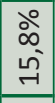 & 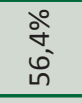 & $\begin{array}{l}\stackrel{0}{0} \\
\infty \\
-1 \\
n\end{array}$ & $\begin{array}{l}\text { ১े } \\
\text { ঢे }\end{array}$ & & & 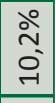 & $\begin{array}{l}\text { वे } \\
\text { ने } \\
\end{array}$ & $\begin{array}{l}\text { oे } \\
\text {-i } \\
\end{array}$ & $\begin{array}{l}\text { ठे } \\
\text { o }\end{array}$ & $\begin{array}{l}\text { ठ̊. } \\
\text { o. }\end{array}$ & $\begin{array}{l}\text { ळे } \\
\infty \\
+\end{array}$ & 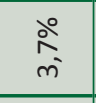 & $\begin{array}{l}\stackrel{2}{\circ} \\
\stackrel{-}{-} \\
-1\end{array}$ & $\begin{array}{l}\text { वें } \\
\text { ठे }\end{array}$ & $\begin{array}{l}\text { वें } \\
0 \\
0\end{array}$ & $\begin{array}{l}\text { ஸें } \\
\text { రิ }\end{array}$ & $\begin{array}{l}\stackrel{2}{x} \\
\text { ó }\end{array}$ & $\begin{array}{l}\stackrel{x}{0}^{\circ} \\
0^{\circ}\end{array}$ & \begin{tabular}{l} 
ठे \\
\multirow{+}{*}{}
\end{tabular} & $\begin{array}{l}\text { ठें } \\
\text { ठें }\end{array}$ \\
\hline ஜू & 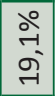 & $\begin{array}{l}\stackrel{0}{\circ} \\
\infty^{\circ}\end{array}$ & 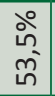 & ભ̊̊ & & & 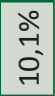 & 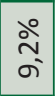 & $\begin{array}{l}\text { oे } \\
\text { ó }\end{array}$ & oें & $\begin{array}{l}\text { 今े } \\
\text { ठे }\end{array}$ & $\begin{array}{l}\stackrel{\circ}{+} \\
\dot{\sim}\end{array}$ & ๙े & $\begin{array}{l}0 \\
6 \\
0 \\
0\end{array}$ & $\begin{array}{l}\text { ठें } \\
0 \\
0\end{array}$ & $\begin{array}{l}\text { वें } \\
0 \\
0\end{array}$ & $\begin{array}{l}\stackrel{\circ}{\dot{े}} \\
\dot{v}\end{array}$ & 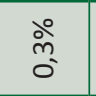 & $\begin{array}{l}\grave{2}^{\circ} \\
\hat{0}^{\prime}\end{array}$ & 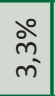 & $\begin{array}{l}\text { ठें } \\
\text { ठิे }\end{array}$ \\
\hline $\begin{array}{l}n \\
\text { } \\
\text { ㄱ }\end{array}$ & $\begin{array}{l}\text { ठे } \\
\text { ¿े } \\
\text { i. }\end{array}$ & $\begin{array}{l}\text { ठ̊ } \\
\text { ஸे } \\
\end{array}$ & \begin{tabular}{l}
$\stackrel{0}{ }$ \\
\multirow{\sigma}{}{} \\
$\dot{\sigma}$
\end{tabular} & $\begin{array}{l}\text { ํํ } \\
\text { ฬे }\end{array}$ & & & $\begin{array}{l}\stackrel{2}{a} \\
\sigma \\
\end{array}$ & $\begin{array}{l}\text { नें } \\
\text { ने }\end{array}$ & \begin{tabular}{|l|}
0 \\
0 \\
0
\end{tabular} & $\begin{array}{l}\text { वे } \\
0 \\
0\end{array}$ & $\begin{array}{l}\text { ठे. } \\
0 \\
0\end{array}$ & $\begin{array}{l}\stackrel{\circ}{m} \\
\stackrel{+}{-}\end{array}$ & $\begin{array}{l}\stackrel{\circ}{~} \\
\text { m }\end{array}$ & $\begin{array}{l}8 \\
6 \\
0\end{array}$ & $\begin{array}{l}\text { ठें } \\
0\end{array}$ & $\begin{array}{l}\text { ठें } \\
0^{\circ}\end{array}$ & $\begin{array}{l}\stackrel{\circ}{-1} \\
\sigma^{\prime}\end{array}$ & $\stackrel{\circ}{\circ}$ & $\begin{array}{c}\stackrel{\circ}{m} \\
\underset{\sim}{-}\end{array}$ & $\begin{array}{l}\stackrel{0}{0} \\
\text { n'- }\end{array}$ & $\begin{array}{l}\text { ठें } \\
\text { ठें }\end{array}$ \\
\hline ह & 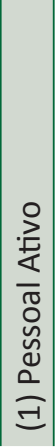 & 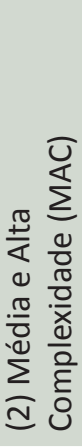 & 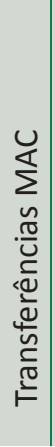 & 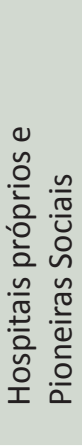 & 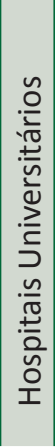 & 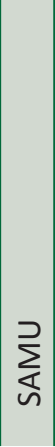 & 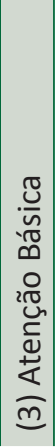 & 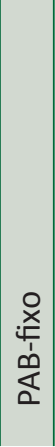 & $\frac{u}{\tilde{n}}$ & $\begin{array}{l}\text { 岕 } \\
\text { 岁 } \\
\frac{x}{\alpha}\end{array}$ & $\begin{array}{l}\overline{0} \\
0 \\
0 \\
0 \\
\overline{0} \\
\tilde{n} \\
\sim\end{array}$ & 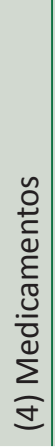 & 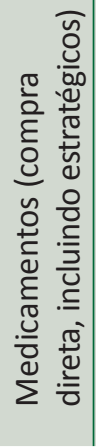 & 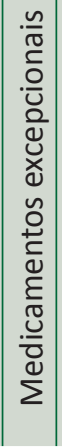 & 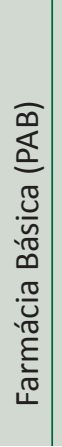 & $\begin{array}{c}\frac{1}{\pi} \\
\frac{\pi}{2} \\
\frac{0}{0} \\
\frac{\pi}{0} \\
\frac{\pi}{0} \\
\frac{\pi}{\pi} \\
\frac{5}{5}\end{array}$ & 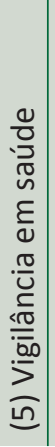 & 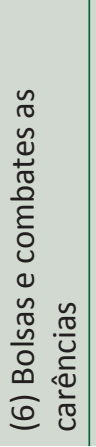 & 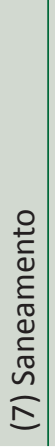 & 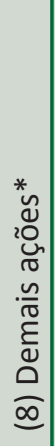 & 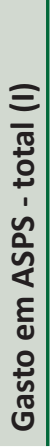 \\
\hline
\end{tabular}




\subsection{Descentralização dos gastos federais}

Apesar de uma das diretrizes do SUS ser a descentralização da gestão para estados, Distrito Federal e municípios, foram muitos os problemas que atrasaram sua implementação. O processo teve início com as Normas operacionais Básicas (NOBs) dos anos 1990. Partindo de um panorama em que as instâncias estaduais e municipais praticamente não participavam da gestão do SUS, o papel dessas NOBs foi principalmente de promover essa participação. Como exemplo deste processo, podemos citar a NOB 01/1993, que marca o início da municipalização com a implantação do caráter automático das transferências intergovernamentais (fundo a fundo) e criação de estágios de gestão descentralizada para estados e municípios; e a NOB 01/1996 que buscou definir atribuições mais claras para os estados, além de incentivar o desenvolvimento de ações estratégicas na área da atenção básica, criando novos mecanismos para o financiamento federal com a instituição Piso de Atenção Básica - fixo e variável. Porém a viabilidade da descentralização só veio a tomar contornos mais concretos a partir da EC29, que conferiu maior estabilidade no fluxo dos recursos federais e trouxe maior segurança para estados e municípios assumirem as responsabilidades da gestão descentralizada.

A intensidade do processo de descentralização da gestão financeira pode ser constatada pela mudança na participação relativa das diferentes modalidades de aplicação dos recursos do MS no gasto total do órgão. Os gastos que em meados dos anos 1990 eram concentrados em aplicações diretas passaram a ser convertidos em transferências a estados, DF e municípios - como demonstra o gráfico 9.

As aplicações diretas do governo federal na provisão de bens e serviços para a saúde passam de 87\% dos gastos do MS 1995 para 31 \% em 2010. No mesmo período, as transferências a estados e ao Distrito Federal apresentam um importante incremento, elevando-se de 6\% em 1995 para 24\% em 2010. As transferências para municípios também apresentaram um importante incremento: elevaram sua participação no total do gasto do MS com saúde de 5\%, em 1995, para 43\% em 2010.

Para entender como se configurou esse processo de descentralização da gestão dos recursos federais, é interessante analisar que tipo de gastos foram delegados para cada uma das instâncias subnacionais de governo. Verifica-se que as transferências a estados e ao Distrito Federal visaram principalmente descentralizar o financiamento dos programas de atenção hospitalar e ambulatorial (e em menor medida, dos programas de assistência farmacêutica). Na modalidade em questão, os gastos descentralizados com atenção hospitalar e ambulatorial, que eram de $\mathrm{R} \$ 3,10$ bilhões em 2001, chegam ao pico de $\mathrm{R} \$ 11,87$ bilhões em 2009 - configurando um aumento de quase $400 \%$ no período. Os programas de assistência farmacêutica também merecem destaque, por saírem de $\mathrm{R} \$ 0,24$ bilhão em 2001 para atingirem níveis de 
R\$2,32 bilhões em 2010 - um aumento de quase 1000\%. A soma das transferências a todos os demais programas não apresenta uma alteração relevante. (Gráfico 10)

Gráfico 09. Distribuição percentual dos gastos federais (MS) em ASPS por modalidade de aplicação, 1995 a 2010

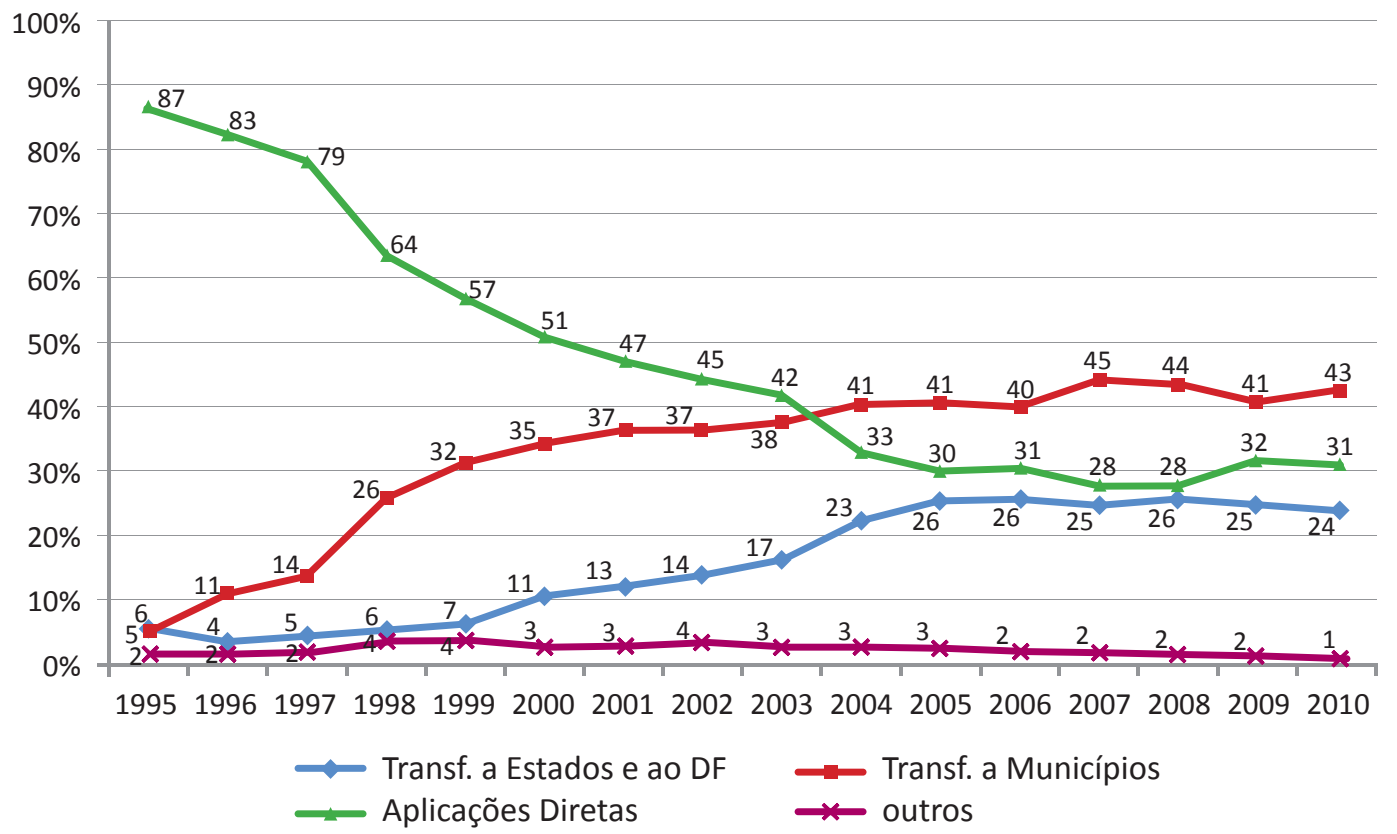

Fonte: SIAFI/SIDOR. Elaboração: IPEA/DISOC.

Gráfico 10. Transferências Federais paraEstados e Distrito Federal, por programas, 2001 a 2010

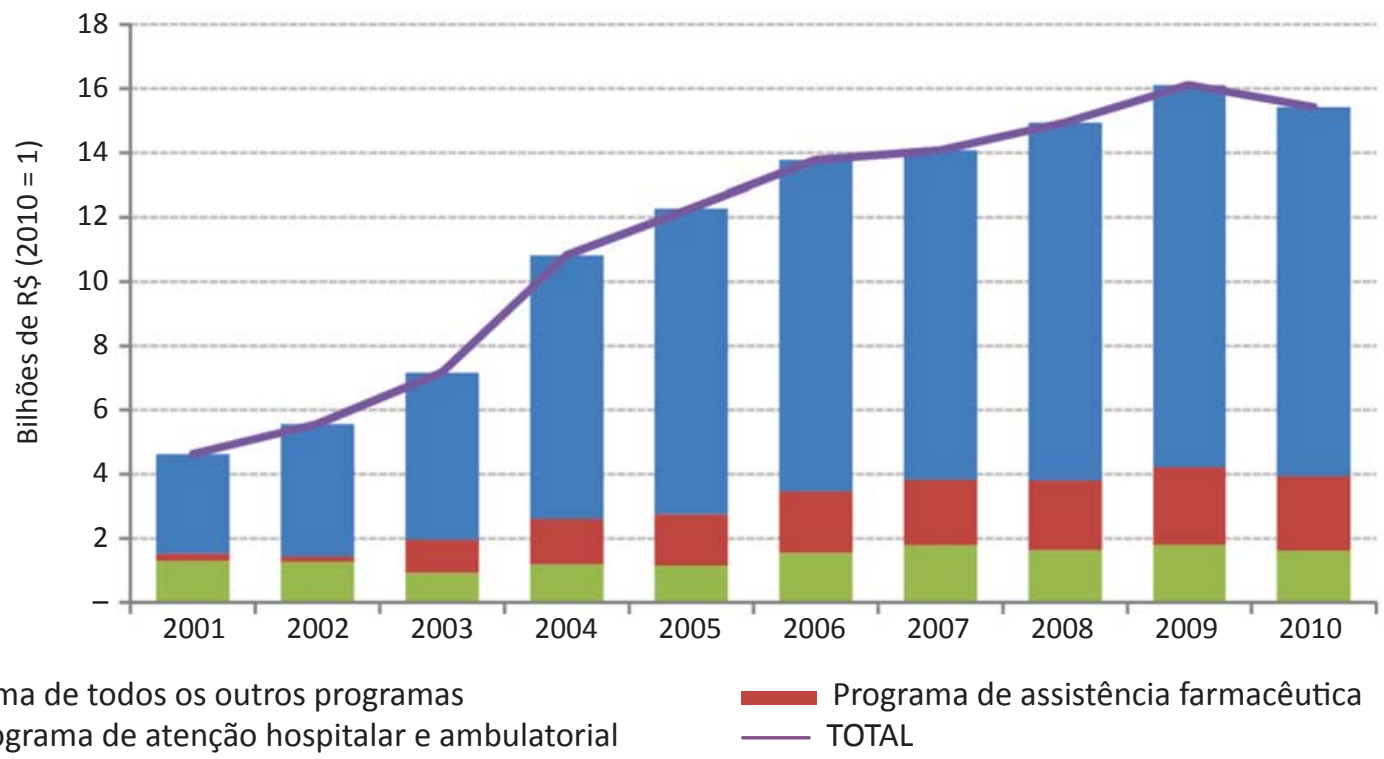

Fonte: Siga Brasil. 
A gestão do financiamento de programas de atenção hospitalar e ambulatorial, que anteriormente tinha uma grande participação do gestor nacional se deslocou para as esferas estadual e municipal (Gráfico 11).

Gráfico 11. Gastos com Atendimento Hospitalar e Ambulatorial: aplicações diretas e transferências, em percentual, 2001 a 2010

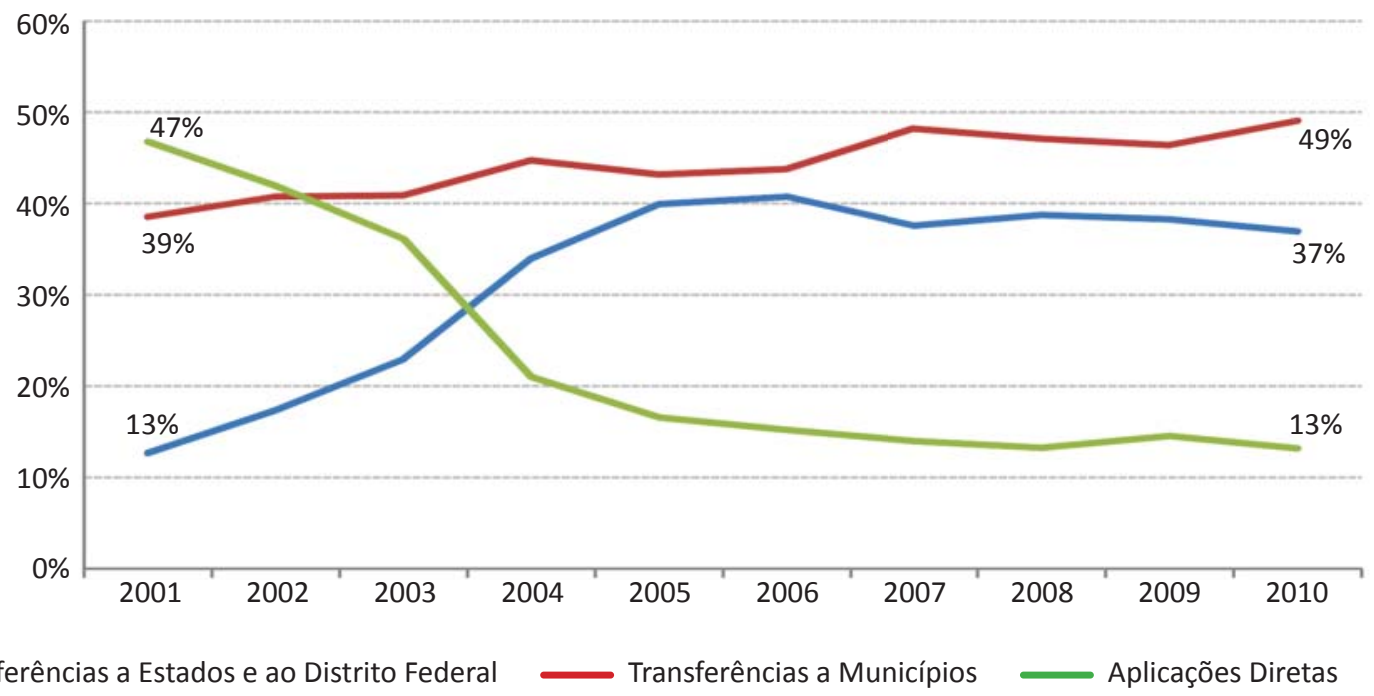

Fonte: Siga Brasil.

Além dessa inversão de papéis entre a esfera federal e estadual observase, também, o aumento do papel dos municípios na gestão de recursos transferidos pelo MS. A participação das transferências a municípios ocupa uma parcela já relevante em 2001 - aproximadamente 38\% do total das transferências - e se eleva a 45\% nos gastos federais totais com ASPS. Isso deixa em evidência que a descentralização se deu com forte participação da esfera municipal e que a esfera municipal também passou a concentrar importante responsabilidade gestora dos recursos federais destinados a ASPS, com participação beirando a 50\% dos recursos transferidos.

Porém, enquanto que o aumento das transferências a estados e ao Distrito Federal se dá principalmente por meio do crescimento da participação da esfera estadual na gestão da atenção hospitalar e ambulatorial, o aumento das transferências a municípios apresenta outro padrão.

O gráfico 12 apresenta uma evolução nominal dos gastos federais com transferência a municípios dividida por programas, com uma apresentação semelhante àquela feita no gráfico 10. Percebe-se que o aumento dos gastos com atenção hospitalar e ambulatorial, tal como dentre as transferências a estados e Distrito Federal, é decisivo para o crescimento das transferências a municípios — indo de R \$9,4 bilhões em 2001 
para $\mathrm{R} \$ 15,2$ bilhões em 2010. Porém, se no caso estadual esta categoria de atenção era praticamente sozinha responsável pelo aumento de suas transferências, aqui ela divide importância com o aumento dos gastos com atenção básica — que vai de R \$5,1 bilhões em 2001 para R\$9,9 bilhões em 2010, apresentando um aumento proporcionalmente maior. E isto é compreensível, uma vez que praticamente a totalidade dos gastos federais com atenção básica se concentra nas transferências à esfera municipal, conforme é mostrado na tabela 9.

Gráfico 12. Transferências Federais para Municípios, por programas, 2001-2010

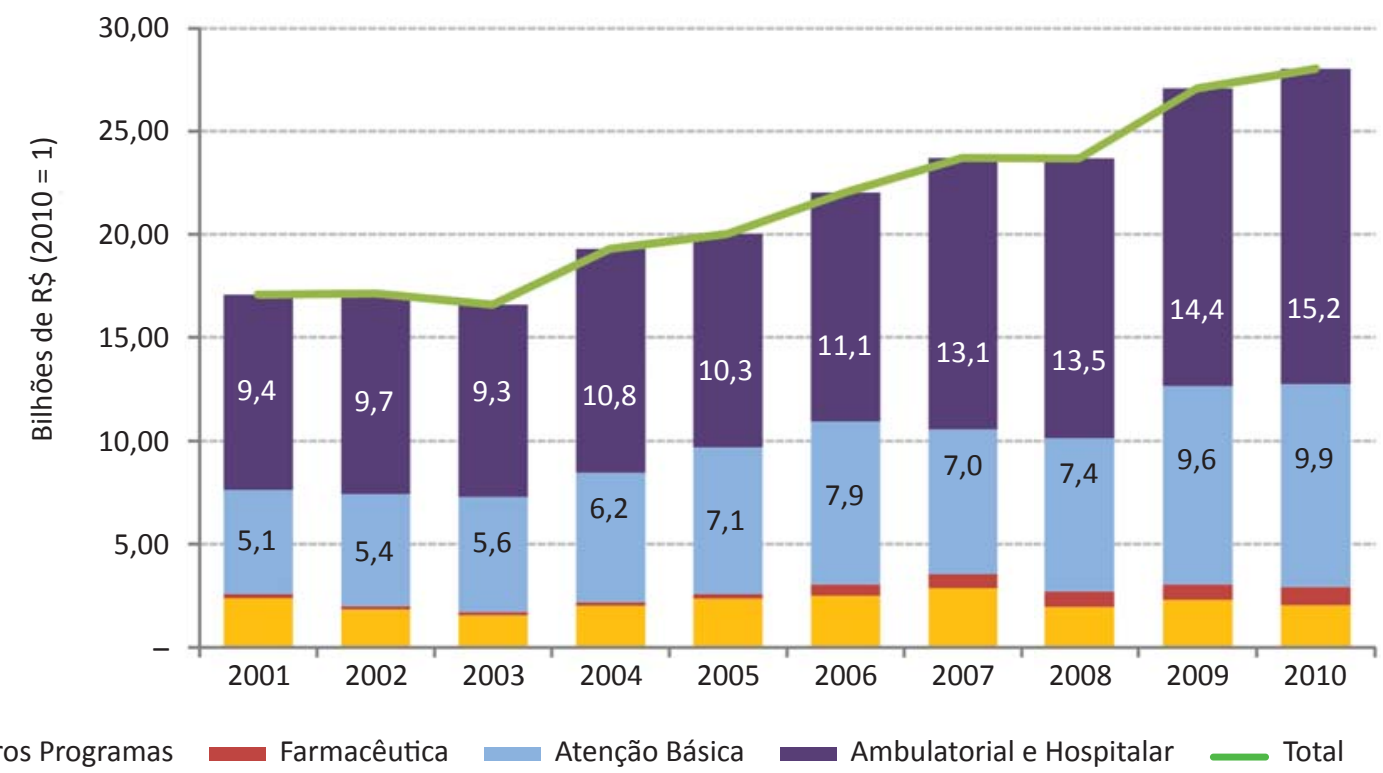

Fonte: Siga Brasil.

Tabela 09. Participação das transferências a municípios nos gastos federais com atenção básica

\begin{tabular}{l|c|c|c|c|c|c|c|c|c|c|}
\hline & 2001 & $\mathbf{2 0 0 2}$ & $\mathbf{2 0 0 3}$ & $\mathbf{2 0 0 4}$ & $\mathbf{2 0 0 5}$ & $\mathbf{2 0 0 6}$ & $\mathbf{2 0 0 7}$ & $\mathbf{2 0 0 8}$ & $\mathbf{2 0 0 9}$ & $\mathbf{2 0 1 0}$ \\
\hline $\begin{array}{l}\text { Aplicações Diretas do } \\
\text { Governo Federal }\end{array}$ & $2,9 \%$ & $1,1 \%$ & $1,2 \%$ & $0,6 \%$ & $0,3 \%$ & $0,7 \%$ & $1,2 \%$ & $1,7 \%$ & $0,8 \%$ & $0,6 \%$ \\
\hline $\begin{array}{l}\text { Transferências a Estados } \\
\text { e ao DF }\end{array}$ & $2,5 \%$ & $0,9 \%$ & $0,8 \%$ & $1,0 \%$ & $1,2 \%$ & $0,8 \%$ & $1,0 \%$ & $1,1 \%$ & $0,8 \%$ & $1,0 \%$ \\
\hline \begin{tabular}{l} 
Transferências a Municípios \\
\hline
\end{tabular} & $93,8 \%$ & $96,8 \%$ & $96,9 \%$ & $97,1 \%$ & $97,5 \%$ & $97,6 \%$ & $97,0 \%$ & $96,3 \%$ & $98,0 \%$ & $97,8 \%$ \\
\hline
\end{tabular}

Fonte: Siga Brasil.

Ainda que o aumento das transferências para estados, DF e municípios tenha sido um aspecto relevante para o processo de descentralização do SUS, existem, 
contudo, restrições da parte destes em relação ao número excessivo de critérios de partilha utilizados para dimensionar os montantes a serem transferidos. Apesar da consolidação das transferências federais em cinco grandes blocos em 2006, por ocasião da aprovação do Pacto pela Saúde, ainda hoje persistem quase duas centenas de modalidades de transferências. Ainda que hoje o gestor local possa, mediante solicitação, remanejar recursos dentro do mesmo bloco, cria-se uma dependência desnecessária. Outra crítica importante refere-se ao fato de que apesar de utilizar critérios para fazer a partilha dos recursos, não há obediência à legislação existente que até hoje não foi regulamentada, particularmente o Art. 35 da Lei 8080/90.

\section{ANÁLISES PROSPECTIVAS E DISCUSSÃO SOBRE CENÁRIOS PARA O FINANCIAMENTO PÚBLICO DA SAÚDE ${ }^{41}$}

No processo de regulamentação da EC 29, em 2011, estavam em discussão projetos com impactos distintos sobre o financiamento da saúde. Naquele momento, havia possibilidade, por meio de lei complementar, de se definir claramente o que seria compreendido como ações e serviços públicos de saúde (ASPS). Em si, essa medida já teria impacto sobre o gasto público em saúde, pois, como dito anteriormente, havia unidades da federação que ainda estariam incluindo como ASPS despesas com saneamento básico, recursos aplicados em benefícios a servidores públicos (clientela fechada), entre outros. Em todos os projetos que estavam em discussão no Congresso, havia previsão de correção dessa situação, impossibilitando a inclusão dessas e de outras ações no cômputo do valor mínimo a ser aplicado.

Outra possibilidade, que também estava em discussão, era o aumento dos recursos federais para saúde, com ou sem mudança da regra de vinculação. A expectativa de aumento dos gastos federais incluía duas propostas de alteração: uma delas vinculando o mínimo a ser aplicado pela União a um percentual da receita corrente bruta (RCB) e outra vinculando a um percentual da receita corrente líquida (RCL). Havia, também, proposta de manutenção da regra de vinculação atual, baseada na variação nominal do PIB, e criação de contribuição, a Contribuição Social para a Saúde (CSS), cujos recursos passariam a integrar, adicionalmente, os recursos federais aplicados em saúde ${ }^{42}$. Com relação às propostas de vinculação do mínimo a ser aplicado pela União a um percentual da receita corrente, no caso da RCB, previa-se um aumento progressivo, começando em 8,5\% até alcançar 10\%, num período de quatro anos ou (ii) vinculação à RCL, com uma vinculação proposta de 18\%, também a ser alcançada progressivamente.

41 Quando estes cenários foram elaborados, a regulamentação da EC 29 ainda não tinha sido aprovada.

42 A criação de nova contribuição social para a saúde foi vetada na passagem da proposta de regulamentação da EC 29 pela Câmara de Deputados. 
Naquele momento, como parte dos trabalhos para compor a publicação Saúde Brasil 2030: diretrizes para a prospecção estratégica do sistema público de saúde brasileiro (FIOCRUZ, 2012), foram elaborados cenários para o gasto em ações e serviços públicos de saúde: (i) Pessimista e Plausível: manutenção das condições observadas em 2010, com a não regulamentação da EC 29 - perspectiva de que o gasto federal continuaria a ser corrigido pela variação do $\mathrm{PIB}^{43}$, sem outros acréscimos de recursos e o gasto estadual e municipal pela evolução das receitas vinculadas ${ }^{44}$, estas últimas crescendo de acordo com diferentes elasticidades em relação ao PIB ${ }^{45}$; (ii) Inercial e Provável: regulamentação da EC 29 com definição do que deveria ser considerado ASPS, mas sem mudança na regra de vinculação dos recursos federais e sem outros recursos adicionais. (iii) Otimista, Desejável e Viável: regulamentação da EC 29 com mudança da regra de cálculo do mínimo a ser aplicado pela União.

Nas próximas seções, serão replicados esses três cenários. Eles foram elaborados, como dito anteriormente, antes da publicação da Lei Complementar n. 141, de janeiro de 2012, que regulamentou a EC 29, com definição do que são ASPS para efeitos do cumprimento do mínimo determinado pela Emenda. Assim, o primeiro cenário não se aplicaria no contexto atual, mas foi mantido para efeitos de comparação.

Ademais, ao se definir o que são ASPS e manter a aplicação de recursos da União vinculada ao crescimento do PIB, pode-se continuar trabalhando com o segundo cenário, que, no momento em que foi elaborado, fora considerado como sendo o mais provável (inercial e provável). O terceiro cenário continua sendo otimista, visto que não há previsão de curto ou médio prazos para mudança na regra de vinculação de recursos da União. Além disso, deve-se considerar a promulgação da Lei Complementar 141 e destacar que os cenários apresentados consideraram uma projeção de crescimento econômico baseada em anexos da LDO 2012 (projeções elaboradas em 2011). Essas projeções, comparadas aos resultados da variação do PIB divulgados no primeiro trimestre de 2013, relativos ao quarto trimestre de 2012, podem ser consideradas otimistas.

43 A LDO 2012, no anexo 3.5, que trata dos cenários para os regimes previdenciários, trazia projeções de variações do PIB real e de inflação até 2050. Para aquela publicação, os cenários foram construídos considerando as informações até 2030.

44 As LDOs estaduais apresentavam cenários para a receita total para o ano da Lei (naquele momento, para 2012) e os dois anos subsequentes (2013 e 2014). Assim, não havia nessas leis projeções até 2030. Contudo, nessas LDOs havia informações sobre as variáveis que foram consideradas para o cálculo dessas projeções, sendo que as principais eram: as variações esperadas para o PIB e a elasticidade-PIB da receita (quanto varia a receita a partir de uma variação de 1\% do PIB).

45 Estudos tributários apresentaram estimativas para as elasticidades-PIB da receita tributária que variam de 1,0 a 2,3 a depender da metodologia e do período analisado (RODRIGUES, 1999; ABOP, 2006; ABOP, 2009; IPEA, 2009). No exercício realizado para compor a publicação Saúde Brasil 2030 foram utilizadas elasticidade unitária e de 1,1. 


\subsection{Cenário Pessimista e Plausível: não há regulamentação da EC 29}

Esse cenário previa que o volume dos recursos federais continuaria obedecendo à variação nominal do PIB, mas essa variação, ao invés de ser o piso, foi utilizada como o teto ${ }^{46}$ para aplicação de recursos da União na saúde. As mudanças na participação do gasto em saúde de estados e municípios dependeriam basicamente da elasticidade-PIB da receita destas esferas de governo.

Nesta simulação a variação do gasto federal com saúde dependeria do gasto no ano-base multiplicado pela variação nominal do PIB dos dois anos imediatamente anteriores e assim por diante. Utilizando as projeções da LDO 2012 para o PIB até 2030, foram obtidos os valores para o gasto federal com saúde no período 2012 a 2030. Nesse cenário, o gasto federal com ASPS cresceria de 1,82\%, em 2012, para 1,98\% do PIB em 2030 (ver Quadro A1 em anexo).

Os cenários para os gastos estadual e municipal com saúde dependeriam do comportamento esperado da receita vinculada. As parcelas mais importantes dessas receitas são os tributos arrecadados diretamente por cada nível de governo e a parcela de transferências obrigatórias. De forma bastante simplificada, considerou-se que ambas variariam com o PIB. Foram feitos dois cálculos: (i) considerando uma elasticidade unitária - a receita vinculada cresceria na mesma proporção do crescimento nominal do PIB; e (ii) considerando uma elasticidade-PIB da receita de 1,1 - um crescimento da receita $10 \%$ superior ao PIB a cada 10 anos $^{47}$. Adotou-se uma forte hipótese de que os estados iriam manter o percentual médio aplicado em saúde entre 2002 e $2008^{48}$, considerando o percentual que resulta da análise de balanços feita pela equipe do SIOPS. Isso implicaria que os estados aplicariam, em média, 10\% dos seus recursos em saúde. Para os municípios, adotou-se a hipótese de aplicação média de $15 \%$ da receita vinculada ${ }^{49}$. No cenário de elasticidade-unitária, como era de se esperar, a proporção dos gastos estadual

$46 \mathrm{Na}$ verdade a variação nominal, pela Emenda, deveria ser o piso. Na construção do cenário foi, no entanto, considerado como sendo o teto.

47 Também foram feitas estimativas considerando uma elasticidade-PIB da receita de 1,5 a cada 10 anos. Nesse cenário, o gasto público total em saúde alcançaria 5,3\% do PIB, com uma participação federal inferior a 38\%. Esse cenário era pouco provável, visto que projetaria uma carga tributária bruta de mais de 70\% para 2030.

48 Adotou-se a média, porque havia grande variação no valor mínimo aplicado ao longo desse período.

49 Comparando com 2010, haveria uma redução dos gastos estaduais e municipais. Isso se deve ao fato de, em 2010, em média, ter-se estimado uma aplicação estadual de 13\% dos recursos próprios e uma aplicação municipal de $21 \%$ dos recursos próprios, considerando os estados e municípios que informaram o SIOPS até o momento e ainda sem considerar a análise de balanços dos estados. Contudo, optou-se por construir o cenário inercial pela média da aplicação do período 2002 a 2008, considerando o efetivamente aplicado para estados e que poderia haver dificuldades para os municípios, em média, manterem uma aplicação em ASPS superior ao mínimo constitucional. Como não havia análise de balanço dos municípios, não era possível saber o grau de correção das informações prestadas. Seria importante fazer análises de sustentabilidade dos financiamentos municipais considerando o efetivamente aplicado por eles. 
e municipal com saúde como proporção do PIB mantém-se constante em 0,74\% e 0,75\% do PIB, respectivamente. (Quadros A2 e A3 - anexo) ${ }^{50}$.

Neste cenário considerado pessimista e plausível, foi utilizada uma relação unitária entre receita e PIB. Nele o gasto público total em saúde, como proporção do PIB, crescia devido ao aumento do gasto federal em saúde. Isso implicava em um aumento de participação do gasto federal em saúde sobre o gasto público total em saúde. O gasto total aumentaria 0,16 pontos percentuais ao passar de 3,31\% do PIB em 2012 para 3,47\% em 2030 (Quadro 1).

Quadro 01. Cenários para Gasto Público em Ações e Serviços Públicos de Saúde como Proporção do PIB (\%)

\begin{tabular}{|c|c|c|c|c|c|}
\hline Período/Ano & Federal & Estadual & Municipal & Total & $\begin{array}{c}\text { Participação Gasto } \\
\text { Federal sobre Total }\end{array}$ \\
\hline 2012 & 1,82 & 0,74 & 0,75 & 3,31 & 55,08 \\
\hline 2013 & 1,81 & 0,74 & 0,75 & 3,30 & 54,90 \\
\hline 2014 & 1,79 & 0,74 & 0,75 & 3,28 & 54,67 \\
\hline 2015 & 1,80 & 0,74 & 0,75 & 3,29 & 54,79 \\
\hline 2016 & 1,88 & 0,74 & 0,75 & 3,37 & 55,87 \\
\hline 2017 & 1,95 & 0,74 & 0,75 & 3,44 & 56,74 \\
\hline 2018 & 1,95 & 0,74 & 0,75 & 3,44 & 56,77 \\
\hline 2019 & 1,95 & 0,74 & 0,75 & 3,44 & 56,79 \\
\hline 2020 & 1,96 & 0,74 & 0,75 & 3,44 & 56,81 \\
\hline 2021 & 1,96 & 0,74 & 0,75 & 3,44 & 56,82 \\
\hline 2022 & 1,96 & 0,74 & 0,75 & 3,44 & 56,83 \\
\hline 2023 & 1,96 & 0,74 & 0,75 & 3,45 & 56,88 \\
\hline 2024 & 1,97 & 0,74 & 0,75 & 3,45 & 56,93 \\
\hline 2025 & 1,97 & 0,74 & 0,75 & 3,45 & 56,97 \\
\hline 2026 & 1,97 & 0,74 & 0,75 & 3,46 & 57,00 \\
\hline 2027 & 1,97 & 0,74 & 0,75 & 3,46 & 57,03 \\
\hline 2028 & 1,98 & 0,74 & 0,75 & 3,46 & 57,07 \\
\hline 2029 & 1,98 & 0,74 & 0,75 & 3,47 & 57,12 \\
\hline 2030 & 1,98 & 0,74 & 0,75 & 3,47 & 57,16 \\
\hline
\end{tabular}

Fonte: Elaborado a partir dos resultados dos Quadros A1 a A3.

50 Ressalte-se, também, que esses cenários consideram apenas as regras de vinculação e os impactos das variações do PIB. Do ponto de vista federal, as pressões demográficas e sociais não implicaram em um aumento da aplicação de recursos públicos superiores ao piso previsto pela EC 29. No caso dos estados, havia estados que não estariam aplicando o mínimo. As pressões de demanda por serviços de saúde se mostrariam no fato de alguns municípios aplicarem acima do mínimo. Contudo, seria importante discutir a viabilidade de eles continuarem aplicando acima do mínimo. Em um cenário em que houvesse mais pressões do lado da demanda (como, por exemplo, mudança do perfil demográfico), sem crescimento dos recursos, os problemas de cobertura e de tempos de espera poderiam ser amplificados. 


\subsection{Cenário Inercial e Provável: regulamentação da EC 29 sem aumento da participação de recursos federais}

No momento de elaboração do texto-base para a publicação Saúde Brasil 2030, um cenário possível e que acabou se confirmando, era o de regulamentação da EC 29, com definição do que são ações e serviços públicos de saúde, mas sem alteração na regra de vinculação ou recursos novos na área federal. Nesta hipótese seria esperado um aumento da aplicação dos estados que estavam aplicando menos de 12\% de suas receitas vinculadas em saúde. Com isso, haveria um aumento de cerca de $\mathrm{R} \$ 3$ bilhões na aplicação dos estados. Em um cenário de elasticidade-PIB da receita vinculada igual à unidade, os gastos públicos com saúde, de 3,47\% em 2012, alcançariam 3,78\% do PIB em 2030. Com elasticidade PIB da receita de 1,1 (crescimento de 10\% acima da variação do PIB a cada 10 anos), os gastos públicos com saúde foram estimados em 3,96\% do PIB em 2030.

\subsection{Cenário Otimista: mudança na regra de vinculação dos recursos federais}

Esse cenário previa a mudança de regra de vinculação dos recursos da União para a saúde que passaria a ser um percentual da receita corrente (bruta ou liquida). Quando a EC 29 foi regulamentada, não houve mudança de regra, mas essa pretensão ainda continua sendo objeto de disputa política. Assim, ainda que esse seja, hoje, um cenário pouco provável e muito otimista no curto e médio prazos, ele será mantido nesse texto para que se possa discutir o que poderia ter acontecido com o gasto público em ASPS, caso a regra tivesse sido alterada em 2012.

Para esse cenário, foram adotados para a receita da União os mesmos critérios estipulados para as variações das receitas de estados e municípios: (i) receita corrente com elasticidade unitária em relação ao PIB e (ii) um aumento de 10\% da receita a cada 10 anos em relação ao PIB.

Com relação aos cenários para o gasto público total em saúde, considerando as hipóteses acima, observa-se que o patamar da RCB, com elasticidade unitária, implicaria em um crescimento de 0,60\% no gasto total entre 2012 e 2030 (3,62\% para 4,37\%). Variações mais significativas nas expectativas para o gasto público dependeriam do comportamento da RCB ou da RCL e das receitas estaduais e municipais com relação ao PIB, ou seja, se adotada a elasticidade de 1,1 na relação receita/PIB. Nesta hipótese o gasto público total com saúde, como pode ser visto no Gráfico 13, foi estimado em 5,10\% do PIB para 2030, considerando o crescimento de $10 \%$ da RCB a cada 10 anos ou 5,07\% do PIB, considerando o mesmo ritmo de crescimento para a RCL e para as receitas estaduais e municipais. 
Gráfico 13. Comparação dos Cenários para variação do gasto total, considerando o gasto federal vinculado à variação nominal do $\mathrm{PIB}^{(1)}$, à Receita Corrente Bruta $(\mathrm{RCB})^{(2)}$ e à receita corrente liquida $(R C L)-2012$ a $2030^{(3)}$

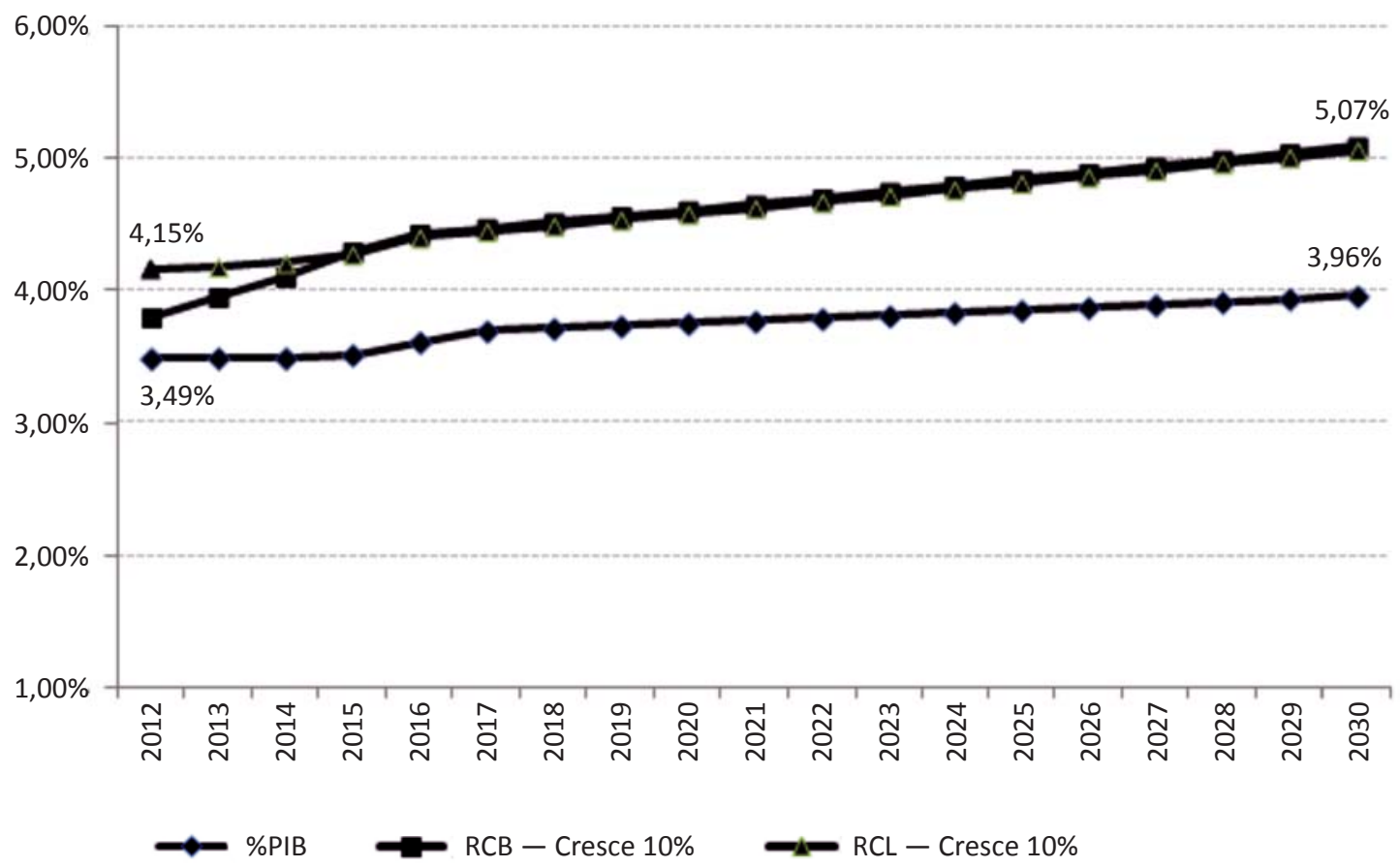

Fonte: SOF. LDO 2012 (PIB). Receita Federal do Brasil/MF. Arrecadação (RCB e RCL 2010). Elaboração própria dos autores.

Nota: (1) Gasto federal vinculado à variação do PIB, mas com regulamentação do conceito de ASPS e com elasticidade receita/PIB de 1,1 para receitas de estados e municípios.

(2) Considerando uma vinculação com base na RCB de 8,5\% até alcançar 10\%. Elasticidade receita/PIB de 1,1.

(3) Considerando uma vinculação de $18 \%$ da RCL desde 2012. Elasticidade receita/PIB de 1,1.

Em valores per capita, o cenário mais pessimista (sem regulamentação, o que não se confirmou, e elasticidade unitária para receitas) apresentaria um crescimento no gasto do SUS de R\$ 750,16 em 2012 para R\$ 973,21 em 2030 (crescimento real de $30 \%$ ). No cenário mais otimista (regulamentação com vinculação do gasto federal à RCB e todas as receitas crescendo com elasticidade receita/PIB de 1,1) o per capita cresceria de $\mathrm{R} \$$ 861,60 em 2012 para $\mathrm{R} \$$ 1.429,32 em 2030, com um aumento real de quase 66\%. Mesmo assim esse valor seria um pouco inferior à receita per capita do segmento de planos e seguros privados de saúde, que em 2010 foi de R\$ 1.594,00. Os valores per capita nos diferentes cenários são apresentados na Tabela 10. 
Tabela 10. Estimativas dos Gastos públicos com saúde per capita real (2012=100), segundo diferentes cenários - Brasil, 2012, 2017, 2022 e 2030

\begin{tabular}{|c|c|c|c|c|c|c|}
\hline $\begin{array}{c}\text { Período } \\
\text { /Ano }\end{array}$ & $\begin{array}{c}\text { Sem } \\
\text { regulamentação } \\
\text { e elasticidade } \\
\text { unitária }\end{array}$ & $\begin{array}{c}\text { Sem } \\
\text { regulamentação } \\
\text { e crescimento } \\
\text { receita } \\
\text { vinculada } 10 \% \text { a } \\
\text { cada } 10 \text { anos }\end{array}$ & $\begin{array}{c}\text { Com } \\
\text { regulamentação } \\
\text { e mantendo } \\
\text { vinculação ao } \\
\text { PIB, receita } \\
\text { vinculada com } \\
\text { elasticidade } \\
\text { unitária }\end{array}$ & $\begin{array}{c}\text { Com } \\
\text { regulamentação } \\
\text { e mantendo } \\
\text { vinculação } \\
\text { ao PIB, } \\
\text { crescimento } \\
\text { receita } \\
\text { vinculada } 10 \% \text { a } \\
\text { cada } 10 \text { anos }\end{array}$ & $\begin{array}{c}\text { Com } \\
\text { regulamentação, } \\
\text { vinculação a } \\
\text { RCB e todas as } \\
\text { receitas com } \\
\text { elasticidade } \\
\text { unitária }\end{array}$ & $\begin{array}{c}\text { Com } \\
\text { regulamentação, } \\
\text { vinculação a } \\
\text { RCB e todas as } \\
\text { receitas com } \\
\text { crescimento de } \\
10 \% \text { a cada } 10 \\
\text { anos (em relação } \\
\text { ao PIB) }\end{array}$ \\
\hline 2012 & 750,16 & 756,66 & 786,81 & 790,68 & 820,64 & 861,60 \\
\hline 2017 & 907,17 & 934,32 & 959,75 & 975,88 & $1.119,48$ & $1.182,26$ \\
\hline 2022 & 939,53 & 988,80 & $1.004,57$ & $1.033,86$ & $1.168,65$ & $1.282,73$ \\
\hline
\end{tabular}

Fonte: Oliveira (2011). Projeção populacional. MPOG.SOF. LDO Nota: Gasto per capita corrigido pelo INPC Acumulado.

Todos esses cenários merecem algumas considerações e ressalvas. Conforme destacado anteriormente, as projeções de crescimento econômico foram feitas pela Secretaria de Políticas Econômicas do Ministério da Fazenda e estão apresentadas no Anexo 3.5 da LDO 2012. Essas projeções, no entanto, poderiam, na época, ser consideradas conservadoras, pois traziam projeções menores para o PIB do que aquelas que foram feitas, na mesma ocasião, por empresas como a Pricewaterhouse e Coopers (PwC), que projetavam uma variação real do PIB menor nos primeiros cinco anos (2011 a 2015), mas apresentam um resultado mais favorável para a economia brasileira a longo prazo (Gráfico 14).

Além dessas ressalvas, cabe observar que se adotou um critério único para expansão das receitas de União, estados e municípios e ao longo de todo o período. Contudo, estudos sobre tributação têm mostrado grandes diferenças nas variações das cargas tributárias ao longo do tempo e entre níveis de governo ${ }^{51}$. Na série de 1990 a 2008, a carga tributária federal aumentou 3 p.p. do PIB. Contudo, esse aumento parece não ser linear. Há momentos de ampliação seguidos de momentos de redução da carga.

Nesse mesmo período, se forem considerados os dois extremos da série, a carga tributária dos estados teria aumentado somente 0,6 p.p. do PIB. Contudo, essa série também apresenta vales e picos. A carga tributária municipal teria aumentado 1\% do PIB, valendo a mesma ressalva sobre as flutuações na série.

51 Agradecemos a José Aparecido Ribeiro, coordenador do Gasto Social Federal, por ter chamado nossa atenção para essas mudanças na carga tributária. 
Gráfico 14. Projeções da Variação Real do PIB de 2011 a 2030

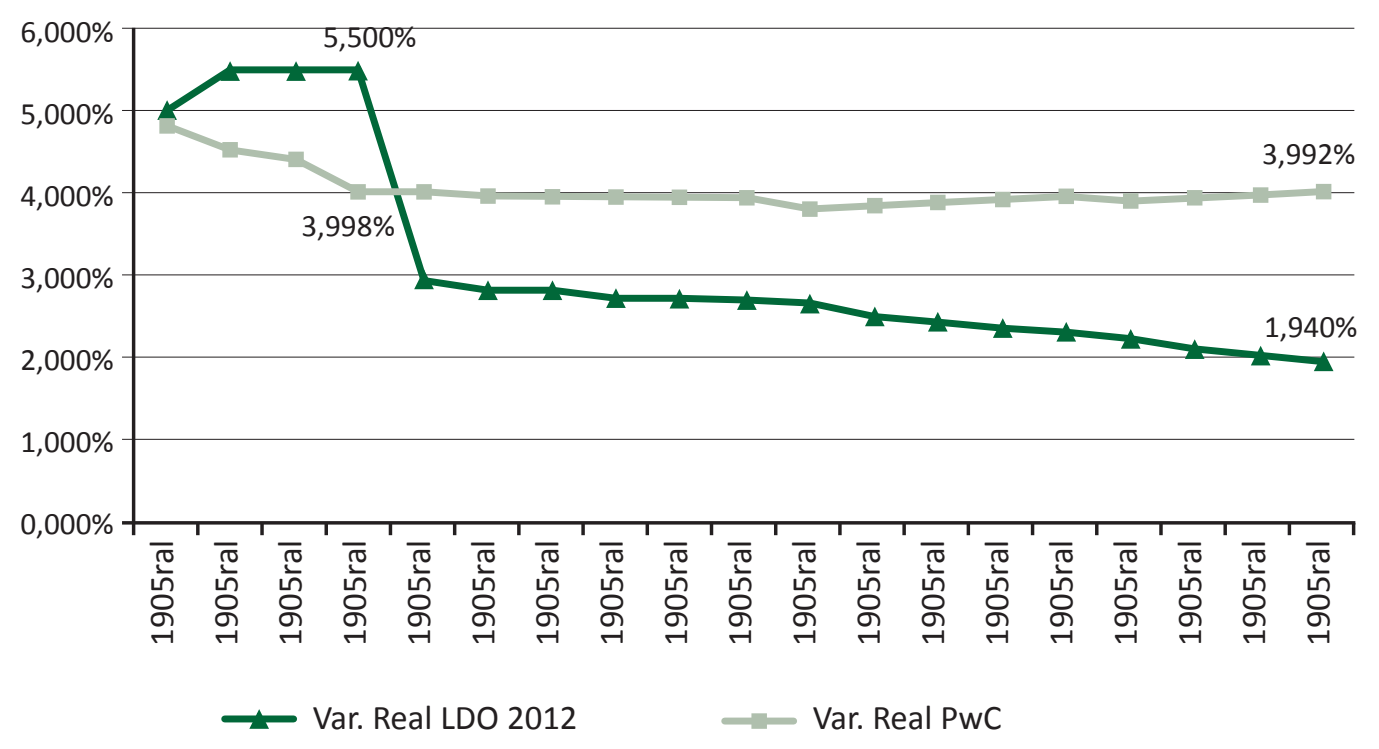

Fonte: SOF. PLDO 2012. PricewaterHouse Coopers (PWC).

Uma análise de uma série mais longa mostra que a carga tributária não tem crescido continuamente. Oliveira (2010) faz uma análise histórica da estrutura tributária brasileira de 1889 a 2009. Ele mostra que, no período entre 1966 a 1970 a carga tributária estimada era de 23,9\% do PIB. No período entre 1971 a 1975, aumentou para 25,3\% do PIB, tendo ficado próximo desse percentual até 1986, quando alcançou 26,5\%.

No ano de promulgação da Constituição Federal de 1988, a carga era de 23,4\% do PIB. Ela cresce a partir de 1991, mas, com alguns saltos no período, que aconteceram em 1994 (crescimento de 2,6\% em relação ao ano anterior); 1999 (crescimento de 1,7\% em relação ao ano anterior) e em 2005 (crescimento de 1\% em relação ao ano anterior).

Esse autor analisa, também, as mudanças institucionais e macroeconômicas que levaram a esses aumentos de carga tributária, mostrando que, entre 1994 a 2009, o primeiro período está mais relacionado ao aumento das receitas por meio de mudanças institucionais, ao passo que os períodos mais recentes têm sido impactados por mudanças macroeconômicas.

Em anos recentes, a máquina arrecadadora modernizou-se, em todos os níveis de governo, e capacitou-se a desempenhar, com eficiência, sua função de cobrar impostos. Para que os caminhos da máquina arrecadadora e da estrutura do sistema tributário convirjam e os impostos possam ser recuperados como instrumentos efetivos de política econômica e social do Estado, resta vencer resistências e realizar uma verdadeira e abrangente reforma do sistema tributário, resgatando importantes 
princípios que devem cimentar suas estruturas, como os da equidade e do equilíbrio macroeconômico e federativo (OLIVEIRA, 2010, p. 211).

Parece ainda haver espaço para melhorar a estrutura de arrecadação, especialmente em estados e municípios. Resumindo, as expectativas sobre o gasto público em saúde dependem da regulamentação da EC/29, mas, também, fortemente, dos cenários para a economia brasileira.

As possibilidades de ampliar o gasto público em saúde, para além da regulamentação da EC 29, dependem de expectativas sobre uma reforma tributária e sobre o comportamento de variáveis macroeconômicas. Dependem, também, das pressões sobre o orçamento público provenientes de outros setores.

\subsection{Elementos para Construção de Cenários para o Gasto Total em Saúde}

Conforme analisado anteriormente, o sistema de saúde brasileiro é financiado por fontes públicas e privadas. Atualmente, mais da metade do gasto em saúde provém de recursos alocados pelas empresas e pelas famílias. Além disso, parte do consumo final de bens e serviços de saúde pelas famílias tem seu preço subsidiado pelo governo e parcela do gasto pode ser restituída por meio dos impostos de renda de pessoa física e jurídica e há ainda outras possibilidades de isenções tributárias e subsídios públicos. Assim, além de alocação de recursos privados, o consumo de bens e serviços pelo mercado conta com subsídios diretos e indiretos do setor público.

A construção de cenários relacionados à composição do financiamento e do gasto total (público e privado) e seu volume dependem de expectativas quanto à atuação do governo, dos partidos políticos, da sociedade civil organizada e de outros segmentos sociais em defesa de posições mais ou menos favoráveis à estruturação de um sistema de saúde baseado majoritariamente em financiamento público ${ }^{52}$ ou em defesa do crescimento da oferta de serviços mediada pelo segmento de planos e seguros de saúde. Dependem, também, da gestão e organização do sistema público de forma que a sociedade perceba que pode utilizar e contar com serviços públicos de qualidade, reduzindo o recurso aos serviços intermediados por planos e seguros de saúde.

Assim, além da organização social e política brasileira, a estruturação de um sistema público universal depende das expectativas e possibilidades na repartição público-privada no financiamento do sistema e oferta de serviços de saúde, bem como da capacidade e interesse dos agentes do Estado para regular essa relação visando a priorização do sistema público.

52 O sistema de saúde do Brasil baseado em direitos incorpora conceitos dos modelos prevalentes na Europa Ocidental no final da década de 70 e ao longo dos anos 80. Esses modelos, além da prevalência do financiamento público destacado anteriormente adotam, também, modelos determinados de organização de sistema de saúde (CEBES, 2010, p.6). 


\subsubsection{Cenário pessimista e plausível}

No momento em que foi elaborado, neste cenário previa-se a manutenção, ou até mesmo um maior favorecimento das regras de subsídio para o consumo privado de bens e serviços de saúde e ampliação do número de operadoras de planos de saúde com rede de serviços pouco estruturada e a incorporação de novos segmentos populacionais mediante a flexibilização de coberturas assistenciais. Não havia perspectivas de regulamentação da EC 29. Com isso, ampliava-se ainda mais a participação privada no financiamento e na oferta de serviços de saúde e era reforçada a perspectiva de um sistema público de atenção a saúde direcionado para os segmentos mais pobres, mas com serviços de baixa qualidade e de escassa incorporação tecnológica. Os serviços mais caros e de maior complexidade eram utilizados pelos segmentos de maior renda e cada vez mais como forma de subsídio ao funcionamento dos planos e seguros de saúde. O resultado final era a ampliação das dificuldades de acesso da população à assistência médica, com privilégios cada vez mais expressivos para determinados segmentos da população.

\subsubsection{Cenário inercial e provável}

Os subsídios diretos e indiretos do governo ao setor privado seriam mantidos nos níveis de 2011 ou cresceriam discretamente. Não seriam resolvidos os problemas decorrentes das situações de imbricamento entre o financiamento público e privado da saúde. O gasto total cresceria e seria mantida, sem maior alteração, a relação percentual entre participação pública e privada no financiamento total. Nesse cenário a EC 29 seria regulamentada, sem mudança na regra de vinculação da União, mas com clara definição do que eram ações e serviços públicos de saúde. Assim, os recursos públicos para o SUS, apesar de apresentarem crescimento não tão discreto, continuariam não sendo suficientes para melhorar substantivamente a qualidade dos serviços prestados pelo sistema público.

\subsection{3| Cenário otimista e desejável}

Nesse cenário, os subsídios diretos e indiretos do governo ao setor privado seriam gradativamente reduzidos e ampliava-se o financiamento público para a saúde, pela regulamentação da EC 29, com a mudança da regra de vinculação dos recursos da União e porque novas fontes de recursos eram destinadas para a saúde por meio de revisão dos mecanismos tributários e ampliação da eficiência e equidade do sistema tributário nacional (União, estados e municípios), repartição dos royalties do petróleo e dos fundos do pré-sal visando à consolidação nacional de um sistema público de prestação de serviços, com clara e inequívoca priorização do SUS no financiamento público. 
Para isso, seriam adotadas medidas reguladoras e de financiamento que, ao mesmo tempo em que fosse reduzindo os subsídios diretos e indiretos para o setor privado, fosse tornando o SUS, em todos os seus níveis, mais atrativo para a classe média e os segmentos da população que se encontram no último quartil da distribuição pessoal da renda.

Em 2013, ainda que a EC 29 tenha sido regulamentada, há vários indicativos de ampliação dos subsídios públicos ao setor privado, sem aumento significativo de recursos públicos para a saúde de caráter universal. Desta forma este último cenário mostra-se cada vez mais distante e exigirá um reforço continuado da luta política em favor do aumento de recursos públicos para o SUS e restrição à ampliação dos incentivos públicos ao setor privado.

\section{5 | CONSIDERAÇÕES FINAIS}

Desde o início de sua implantação, no final da década de 1980, o SUS tem convivido com problemas de financiamento. Iniciativas foram tomadas para minorar, pelo menos em parte, o problema. A aprovação da CPMF, em 1996, e da Emenda Constitucional 29, em 2000, foram as mais importantes.

A EC 29 talvez tenha sido a que trouxe melhores resultados, seja pelo aporte de recursos propiciado ao sistema (cerca de 1\% do PIB entre 2000 e 2010), seja por ter incorporado os estados, DF e municípios, de forma mais consistente e solidária, no financiamento do SUS, uma vez que dois terços do aumento de recursos no período citado foram provenientes de recursos próprios dessas instâncias de governo. Mas, ao mesmo tempo em que isso ocorria, o Governo Federal, também manteve e até aumentou o gasto tributário decorrente de isenções fiscais, principalmente relacionadas ao Imposto de Renda, à saúde privada, em nítido descompasso com o comprometimento exclusivo que deveria ter com o sistema público e universal.

Por outro lado, o avanço na implantação do SUS, principalmente a implementação da diretriz de descentralização, provocou mudanças significativas na execução financeira do MS, com diminuição exponencial das aplicações diretas e aumento das transferências para estados, DF e municípios. Mudanças também se verificaram na execução financeira por programas/ações. O novo perfil reflete as novas prioridades que a direção nacional tenta imprimir ao modelo de atenção do SUS, com destaque para as aplicações na área de atenção básica. Contudo, nem o aumento das transferências federais para as esferas subnacionais, nem a eleição de novas prioridades foram suficientes para reduzir, de forma significativa, as desigualdades existentes na alocação regional de recursos para as ações e serviços públicos de saúde. 
A aprovação da regulamentação da EC 29 em janeiro de 2012 certamente propiciará incremento de recursos para o SUS, ao resolver problemas que levavam à perda de recursos, decorrente de inúmeros estratagemas. Nada obstante, não foi aprovada a mudança no critério de vinculação dos recursos federais para o sistema, o que poderia significar um aumento maior no volume de recursos.

Os cenários para o financiamento público da saúde apresentados neste trabalho representaram uma aproximação de diferentes perspectivas para o financiamento e gasto do sistema de saúde no Brasil. Não são projeções do futuro nem tem a pretensão de apresentar, com maior rigor, valores esperados para o volume dos recursos públicos e possibilidades para o gasto total. O objetivo principal era, quando foram elaborados, o de apresentar para debate, cenários que, considerando a situação então vigente e considerando algumas possibilidades futuras, poderiam trazer implicações para o financiamento da saúde. Para efetivamente estimular a discussão sobre cenários futuros é necessário aprofundar o debate e desenvolver estudos sobre alguns temas como, por exemplo, os listados a seguir:

1. ter claro qual o modelo de sistema de saúde que se quer para o Brasil;

2. fazer estudos sobre as tendências de investimento do setor privado, com claro conhecimento das inter-relações entre as diversas empresas que compõem esse segmento;

3. analisar as possibilidades e fontes de financiamento para o setor público;

4. realizar estudos que possibilitem ter uma base mais clara sobre as necessidades de financiamento para o setor público, considerando as necessidades de investimento, recursos humanos e custeio para a estruturação de um modelo de sistema de saúde para o país;

5. analisar as proposta de medidas possíveis, viáveis e desejáveis de regulação da relação público-privada.

Além disso, será necessário:

1. melhorar nossos sistemas de informações para se ter um conhecimento mais adequado do gasto funcional com saúde realizado por estados e municípios;

2. ter informações disponíveis e ampliar nossa capacidade analítica sobre os diversos mecanismos de financiamento do setor público direcionados ao setor privado; 
3. debater com pessoas que estejam acompanhando e analisando a atuação do Congresso a regulação do sistema brasileiro de saúde;

4. recolocar no debate político a necessidade de consolidar o sistema público de prestação de serviços, com clara e inequívoca priorização do SUS no financiamento público;

5. analisar os cenários internacionais e as perspectivas que se colocam para manutenção e estruturação de sistemas públicos universais. 


\section{6 | REFERÊNCIAS BIBLIOGRÁFICAS}

ABOP. Associação Brasileira de Orçamentos Públicos. Análise de alguns dados financeiros agregados dos orçamentos fiscal, da seguridade social e de investimento da união de 2009. Informe n. 75, março de 2009.

Análise de alguns dados financeiros agregados dos orçamentos fiscal, da seguridade social e de investimento da união de 2006. Informe n. 69, março de 2006.

BARROS, ME; PIOLA, SF e VIANNA, SM. Políticas de Saúde no Brasil: Diagnóstico e Perspectivas, Brasília: IPEA, Texto para Discussão n 401, 1996.

BIASOTO JR., G. Setor Saúde: constituição do SUS, financiamento federal, transferências e questões federativas. (mimeo) IE/UNICAMP: Campinas, 2003.

BRASIL. MINISTÉRIO DA SAÚDE. AGÊNCIA NACIONAL DE SAÚDE SUPLEMENTAR (ANS). Caderno de Informação de Ressarcimento e Integração com o SUS. No 1, Volume 5, julho de 2009.

Caderno de Informação da Saúde Suplementar: beneficiários, operadoras e planos. Dados eletrônicos. Rio de Janeiro: ANS, 2012.

BRASIL. MINISTÉRIO DA SAÚDE. Sistema de informações sobre orçamentos públicos em saúde (SIOPS). Minuta de Análise dos Gastos da União em Ações e Serviços Públicos de Saúde, no período 2000 a 2010. Documento elaborado por subgrupo da Câmara Técnica do SIOPS, Brasília, outubro 2011, mimeo.

BRASIL. SECRETARIA DA RECEITA FEDERAL DO BRASIL. Imposto de Renda Pessoa Física: manual de preenchimento. Declaração de Ajuste Anual Modelo Completo. Ano-calendário 2008. Brasília, 2009.

BRASIL. SECRETARIA DA RECEITA FEDERAL DO BRASIL. Demonstrativo dos Gastos Tributários - Estimativas Bases Efetivas - 2009 - Série 2007 a 2011. Brasília, 2012. Disponível em http:// www.receita.fazenda.gov.br/publico/estudotributario/BensTributarios/2009/DGTAC2009.pdf

CASTRO, J. A. de et al. Gasto Social e Política Macroeconômica: trajetórias e tensões no período 1995 - 2005. Brasília: IPEA, Texto para Discussão n 1324, janeiro de 2008.

CONASS. Conselho Nacional de Secretários de Saúde. O Financiamento da Saúde. Brasília: CONASS, 2011. 124 p. (Coleção "Para entender a gestão do SUS", n² 2).

CONASS. Conselho Nacional de Secretários de Saúde. O Financiamento da Saúde, Brasília: CONASS, 2007. 164 p (Coleção Progestores — Para entender a gestão do SUS, nº 3).

CEBES. Política Pública de Saúde: Qual o Rumo? RJ, 2010.

DINIZ, B.P.C. et al. (2007b) Gasto das famílias com saúde no Brasil: evolução e debate sobre gasto catastrófico. In Silveira, F.G. et al. (Org.) Gasto e consumo das famílias brasileiras contemporâneas. Brasília, IPEA, vol. 2, 2007.

FERNANDES, M. A. et al. Gasto Social das Três Esferas de Governo: 1995. Texto para Discussão n. 598. IPEA: Brasília, 1998. 
FUNDAÇÃO OSWALDO CRUZ (FIOCRUZ). A Saúde no Brasil em 2030 - Diretrizes para a Prospecção Estratégica do Sistema de Saúde Brasileiro", Fundação Oswaldo Cruz. (et. al.). Rio de Janeiro:Fiocruz/IPEA/MS/SAE/PR, 2012.

HSIAO, W. Why is a systemic view of health financing necessary? Health Affairs, Vol. 25, n 4, p. 950-961, july/august 2007.

IBGE. Instituto Brasileiro de Geografia e Estatística. Projeção da População do Brasil por Sexo e Idade - 1980-2050 - Revisão 2008. Diretoria de Pesquisas/ Coordenação de População e Indicadores Sociais. Rio de Janeiro: IBGE, 2008.

Janeiro, 2012.

Conta Satélite de Saúde, Brasil 2007 - 2009. Contas Nacionais, número 37, Rio de

IPEA. Instituto de Pesquisa Econômica Aplicada. Políticas Sociais: acompanhamento eanálise — Instituto de Pesquisa Econômica Aplicada. No 13, Edição Especial, 2007.

Políticas Sociais: acompanhamento e análise — Vinte Anos da Constituição Federal — Instituto de Pesquisa Econômica Aplicada. Volume 1 n 17, 2009a.

Políticas Sociais: acompanhamento e análise - Instituto de Pesquisa Econômica Aplicada. n 19, 2011.

Diretoria de Estudos e Políticas Macroeconômicas. O que explica a recente queda da receita tributária federal? IPEA: Brasília. Nota Técnica n. 14, agosto de 2009b.

KUTZIN J et. al. Lessons from health financing reform in central and eastern Europa and former Soviet Union; Health Economics, Policy an Law; Vol. 5, abril, 2010, Cambridge University Press.

MENDES, A; MARQUES, R. A Saúde Pública sob a Batuta da Nova Ordem. In: MARQUES, R; FERREIRA, M (Orgs.). O Brasil sob a nova ordem: a economia brasileira contemporânea: uma análise dos governos Collor a Lula. São Paulo: Saraiva, 2009.

OLIVEIRA, F.A. A evolução da estrutura tributária e do fisco brasileiro: 1889-2009. In: CASTRO, JÁ; SANTOS, CHM; RIBEIRO, JAC (Org.). Tributação e equidade no Brasil: um registro da reflexão do IPEA no biênio 2008-2009, Brasília: IPEA, 2010.514 p.: gráfs., tabs.

OMS. Organização Mundial da Saúde. Informe de Estadisticas Sanitárias Mondiales. Genebra, 2008.

Informe sobre la Salud en el Mundo.Genebra, 2000

OPAS. Organização Panamericana da Saúde. Health in the Americas, 2007 - Volume I Regional.

PIOLA, SF et al. Estado de uma Nação . Textos de Apoio: Saúde no Brasil: Algumas questões sobre o Sistema Único de Saúde. Brasília: IPEA, Texto para Discussão n. 1391, 2008.

PIOLA, S.F. et al. Financiamento Público da Saúde: uma história a procura de rumo. Texto para Discussão. IPEA: Brasília, 2013 (no prelo).

PIOLA, SF; BIASOTO JR, G. Financiamento do SUS nos anos 90. In: NEGRI, B; GIOVANNI, G. (Org.) Brasil. Radiografia da Saúde. Campinas: Unicamp, Instituto de Economia, Campinas, 2001. 
PRADHAN, M e N. PRESCOTT. Social Risk Management Options for Medical Care in Indonesia. Health Economics 11, p. 431-46, 2002.

RODRIGUEZ, J. Elasticidade-PIB de longo prazo da receita tributária no Brasil: abordagem do índice de Divisia: evidências empíricas no período 1975-1997. Brasília, UnB. Dissertação de Mestrado, 1999.

RIBEIRO, JA; PIOLA, SF e SERVO, LMS. As novas configurações de antigos problemas: financiamento e gasto com ações e serviços públicos de saúde no Brasil. Apresentado na II Jornada de Economia da Saúde da ABRES, Belo Horizonte, Dez.2005. Publicado na revista Divulgação em Saúde para Debate, CEBES: Rio de Janeiro.

SCHIEBERet al. Financing global health: Mission unaccomplished. Health Affairs, Vol. 25, n 4, p. 921-934, 2007.

SERVO, L. M. et al. Financiamento e Gasto Público de Saúde: Histórico e Tendências. In MELAMED, C. e PIOLA, S. (orgs) Políticas Públicas e Financiamento Federal do Sistema Único de Saúde. Brasília: IPEA, 2011.

SERVO, LMS; PIOLA, SF; SÁ, EB; PAIVA, AB. Financiamento da Saúde no Brasil. Texto Elaborado para compor a publicação Brasil em Desenvolvimento, Brasília: IPEA, 2011.

Nota técnica 10/2010. Disponível em <http://siops.datasus.gov.br>. Acesso em 12 de dezembro de 2011.

VIANNA, S. M. A seguridade social, o sistema único de saúde e a partilha dos recursos. Revista Saúde e Sociedade, v. 1, n. 1, p. 43-58, 1992.

WAGSTAFF, A., e VAN DOORSLAER, E. Catastrophe and Impoverishment in Paying for Health Care: with Applications to Vietnam 1993-98. Health Economics 12, p, 921-34, 2003.

WAGSTAFF et al. Equity in the finance of helath care: futher internacional comparisons; Journal of Health Economics 18 (1999) Elsevier.

WHO. World Health Statistics 2010. Genebra, 2010.

XU, K. Distribution of health payments and catastrophic expenditures - methodology. Genebra: WHO, 2005 (Discussion paper, n. 2, EIP/HSF).WHO, 2005 (Discussion paper, n. 2, EIP/ HSF). 


\section{ANEXO}

Quadro A1. Cenário inercial para o gasto federal com saúde

\begin{tabular}{|c|c|c|c|c|}
\hline Período /Ano & PIB (Var. Nominal) & Gasto Federal Saúde & PIB Estimado & $\begin{array}{c}\text { Gasto Federal } \\
\text { Saúde/PIB }\end{array}$ \\
\hline 2012 & 1,103 & 81.204.121.503 & $4.455 .029 .785 .740,19$ & $1,82 \%$ \\
\hline 2013 & 1,108 & 89.279 .424 .764 & $4.935 .059 .245 .153,69$ & $1,81 \%$ \\
\hline 2014 & 1,113 & 98.439 .940 .142 & $5.491 .282 .370 .086,10$ & $1,79 \%$ \\
\hline 2015 & 1,102 & 109.046.843.692 & $6.052 .842 .870 .380,58$ & $1,80 \%$ \\
\hline 2016 & 1,065 & 121.337.349.875 & $6.448 .247 .857 .309,63$ & $1,88 \%$ \\
\hline 2017 & 1,064 & 133.745 .792 .622 & $6.861 .474 .148 .873,53$ & $1,95 \%$ \\
\hline 2018 & 1,064 & 142.482 .803 .398 & 7.300.471.264.918,46 & $1,95 \%$ \\
\hline 2019 & 1,063 & 151.613 .600 .130 & 7.760.755.027.464,67 & $1,95 \%$ \\
\hline 2020 & 1,063 & 161.313 .838 .266 & $8.249 .255 .752 .668,43$ & $1,96 \%$ \\
\hline 2021 & 1,063 & 171.484 .433 .798 & $8.767 .651 .358 .049,74$ & $1,96 \%$ \\
\hline 2022 & 1,062 & 182.278.521.483 & 9.314.993.913.204,39 & $1,96 \%$ \\
\hline 2023 & 1,061 & 193.733.177.191 & $9.881 .080 .065 .800,69$ & $1,96 \%$ \\
\hline 2024 & 1,060 & 205.827.455.110 & $10.474 .409 .280 .511,80$ & $1,97 \%$ \\
\hline 2025 & 1,059 & 218.335.898.298 & $11.095 .777 .425 .055,00$ & $1,97 \%$ \\
\hline 2026 & 1,059 & 231.446.313.983 & $11.748 .264 .616 .535,30$ & $1,97 \%$ \\
\hline 2027 & 1,058 & 245.176.287.945 & $12.429 .393 .754 .208,20$ & $1,97 \%$ \\
\hline 2028 & 1,057 & 259.593.879.557 & $13.134 .575 .408 .853,20$ & $1,98 \%$ \\
\hline 2029 & 1,056 & 274.644.353.912 & $13.868 .890 .116 .236,00$ & $1,98 \%$ \\
\hline 2030 & 1,055 & 290.226 .301 .332 & $14.632 .774 .714 .948,10$ & $1,98 \%$ \\
\hline
\end{tabular}

Fonte: Variação Real do PIB e INPC. SOF. PLDO2012. Anexo 3.5.

Gasto Federal em Saúde — 2010 — SIAFI/SIDOR. 2011-2030. Estimado pela variação nominal do PIB. 


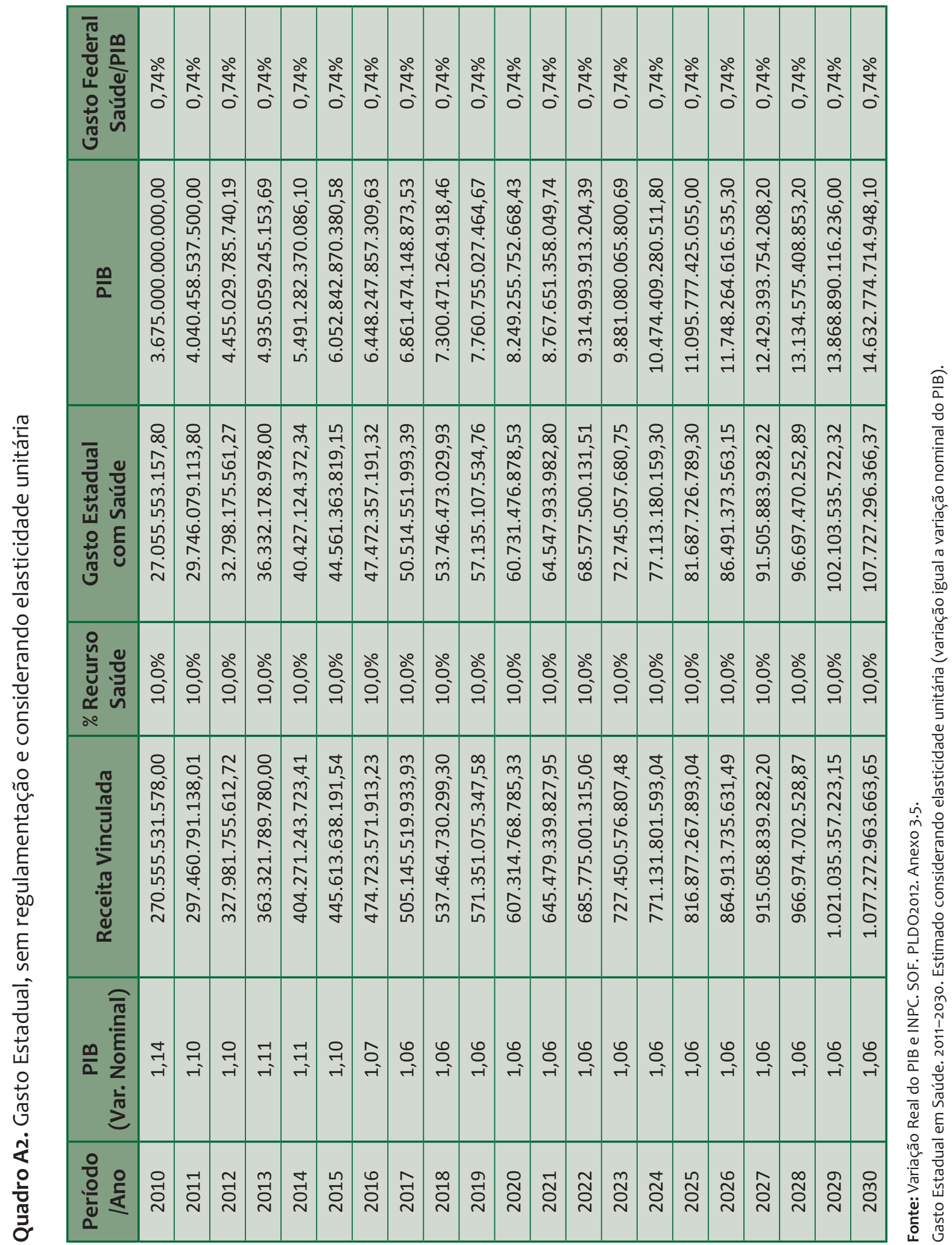




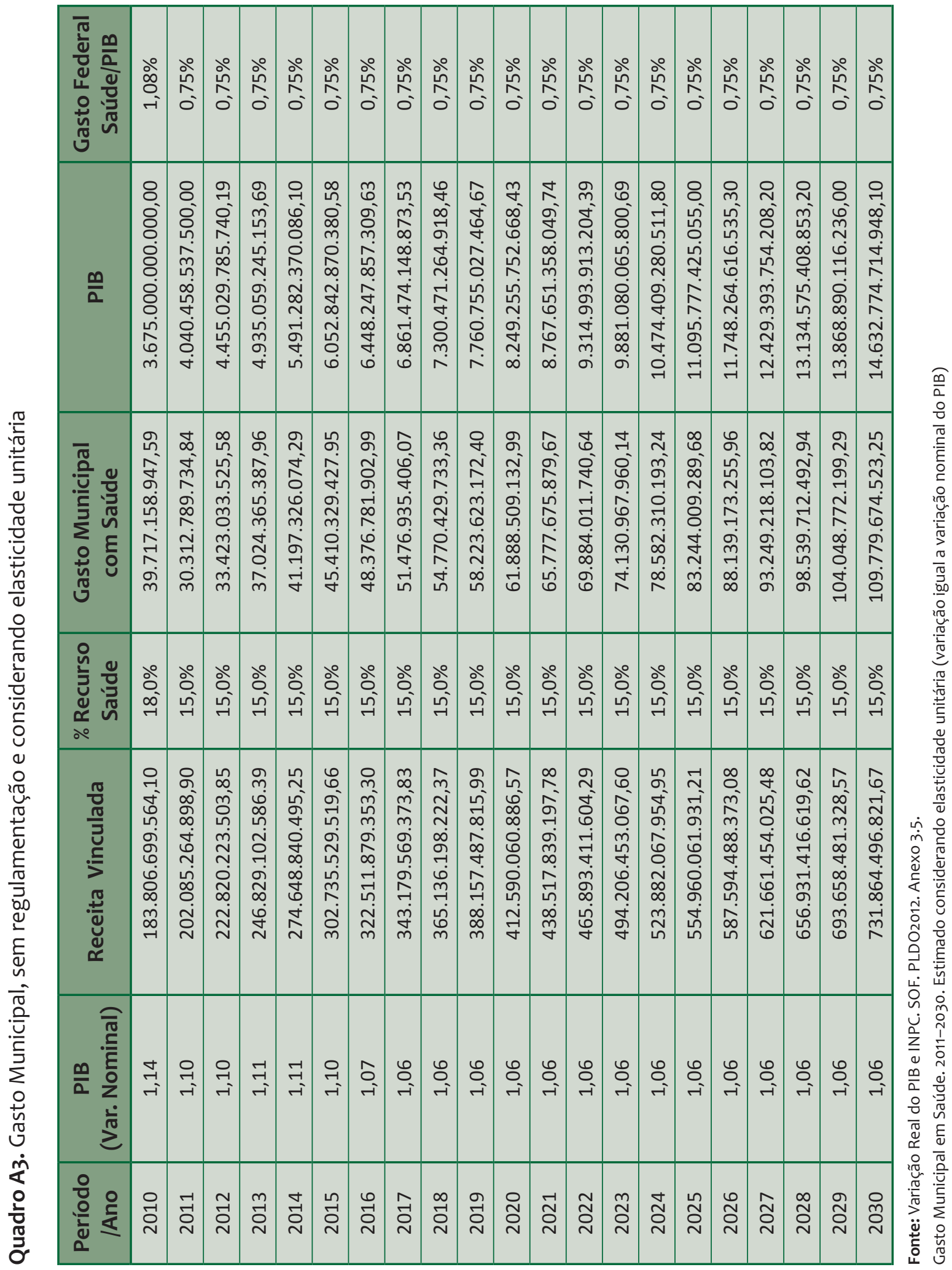

